$$
\begin{gathered}
\text { UNIVERSIDADE DE SÃO PAULO } \\
\text { FACULDADE DE CIÊNCIAS FARMACÊUTICAS } \\
\text { Programa de Pós-graduação em Ciência dos Alimentos } \\
\text { Área de Bromatologia }
\end{gathered}
$$

\title{
Estudo dAs Condições de PROCEsSAMENTO PARA Obtenção de Isolado Protéico de Soja com Teor AUMENTADO DE ISOFLAVONAS
}

ANA CRISTINA LOPES BARBOSA

Dissertação para obtenção do grau de MESTRE 


\section{Ana Cristina Lopes Barbosa}

Estudo das Condições de Processamento para Obtenção de Isolado Protéico de Soja com Teor Aumentado de Isoflavonas

Comissão Julgadora

da

Dissertação para obtenção do grau de Mestre

Prof. Dr. Maria Inés Genovese

orientador/presidente

Prof. Titular Franco Maria Lajolo

10 examinador

Prof. Dr. Flávia Maria Netto

$2^{\circ}$ examinador

São Paulo, 15 de fevereiro de 2004. 
Aprender é descobrir aquilo que você já sabe Fazer é demonstrar que você o sabe Ensinar é lembrar aos outros que eles sabem tanto quanto você Somos todos aprendizes, fazedores, professores Você ensina melhor aquilo que mais precisa aprender (Richard Bach, in Ilusões) 
Dedico este trabalho Em especial, aos meus pais Miguel e Elizabeth Aos meus irmãos Marcel, Caio, Agda e Junior

pelo incentivo enorme que tive em toda minha vida. 


\section{AGRADECIMENTOS}

Sinceros agradecimentos aos meus pais, aos mens irmãos, e aos mens avós pela cumplicidade, pelo apoio, pelo conforto e principalmente pela compreensão da minha ausêncía em alguns momentos do convivio familiar. A presença deles na minha vida, e nos momentos de maior dificuldade, acima de tudo, mostraram o real significado das palavras: coragem e perseverança.

Agradeço a Profa. María Inés Genovese pela orientação, pelo seu exemplo, incentivo, dedicação, confiança, apoio e amizade. Creio que a confiança e amizade são os melhores presentes que podemos receber. Além da minha admiração por uma grande pesquisadora e muther.

Agradeço a Cirlene e Daniella pela amizade eterna, sempre me incentivando e me dando ânimo.

Agradeço a Neuza e Lúcía pelas palavras sábias, pelo incentivo e principalmente pelo carinho.

Agradeço também aos professores do Departamento de Alimentos, Profa. Beatriz, Profa. Elizabeth, Prof. Eduardo, Prof. João Roberto, Prof. Franco Lajolo que em algum momento me brindaram com sew auxítio.

Agradeço aos meus professores que colaboraram na minha formação acadêmica Marcia, Elizew, Leonardo, Valdir e Thais, e em especial a Magali que sempre acreditow no mew potencial e foi a primeira a me incentivar nessa jornada e a grande amiga e orientadora Ana Lúcia do Ital (Campinas), que me encorajow a fazer a pós-graduação.

Ao pessoal da Secretaria de Alimentos e Nutrição Experimental, Mônica, Isabel, e Tânia, e da Secretaría de Pós-Graduação, Jorge e Elaine, sempre solicitos e gentis.

Há certas pessoas que agradecemos em nossas preces por coisas que apreciamos tanto mas, por mais que tentemos, às vezes não conseguimos dizer as palauras que expressariam tudo isso. Agradeço de forma muito especial ao Adair, Aderuza, Adriana, Ana Paula, Eliana, Giselli, Gracielli, Janaina, Jacquetine, João Paulo, Malu, Márcia, Marcinha, Mauricio, Milana, Paola, Priscita, Ricardo, Rose, Tânia, Walter pela 
solidariedade e a amizade, e também pelas discussóes que muito contribuiram para que este trabalho fosse reatizado.

A CAPES pela bolsa, e à FAPESP pelo suporte financeiro do laboratórío.

Por fim agradeço ao Nosso Pai Maior pela oportunidade da vida e de aprender. Por ser o alicerce da minha vida e a força que muitas vezes me dew ânimo e a coragem de levantar e prosseguir até o fím dessa etapa.

Sou grata a todos aqueles que de certa forma fizeram parte deste trabalho. Obrigada. 


\section{RESUMO}

Os isolados protéicos de soja são utilizados como ingredientes em diversos alimentos e sua utilização vêm aumentando juntamente com o aumento das pesquisas sobre os metabólitos secundários da soja, as isoflavonas. Alguns efeitos benéficos vem sendo associados às isoflavonas, entre estes a sua ação antioxidante, a prevenção de câncer, doenças cardiovasculares e osteoporose. O objetivo deste estudo foi o de otimizar as condições de extração das isoflavonas e de suas formas conjugadas a partir da farinha desengordurada de soja, visando o preparo de isolado protéico de soja. Os resultados mostraram que a obtenção de isolados protéicos de soja com teor aumentado de isoflavonas depende da utilização de condições brandas de centrifugação para a separação do precipitado isoelétrico, assim como da utilização de água acidificada na sua lavagem. A presença de isoflavonas no isolado resulta de três fatores, o primeiro referindo-se à associação entre isoflavonas e proteínas através de interações hidrofóbicas, eletrostáticas, e pontes de hidrogênio; 0 segundo à menor solubilidade das isoflavonas presentes na farinha desengordurada de soja no $\mathrm{pH}$ isoelétrico; e o último ao processo de carreamento (físico) das isoflavonas pelas proteínas insolubilizadas.

PALAVRAS-CHAVE: isoflavonas, proteínas da soja, processo de obtenção de isolado protéico de soja. 


\section{SUMMARY}

Soy protein isolates are used as ingredients in several food products and their use is increasing together with the increase of the researches on the secondary metabolites of soy, the isoflavones. Some beneficial effects have been associated to the isoflavones, among these their antioxidant action, prevention of cancer, cardiovascular diseases and osteoporosis. The objective of this study was to optimize the extraction conditions of the isoflavones from the defatted soy flour, seeking the preparation of soy protein isolates. The results showed that the obtention of soy protein isolates with increased content of isoflavones depends on the use of mild conditions of centrifugation for the separation of the isoelectric precipitate, as well as on the use of water acidified in the washing step. The presence of isoflavones in the isolates resulted from three factors, the first refers to the association between isoflavones and proteins through hydrophobic; and electrostatic interactions, and hydrogen bonding; the second to the decreased solubility of the isoflavones extracted from the defatted soy flour in the isoelectric $\mathrm{pH}$; and the last to the carrying process (physical) of isoflavones by the precipitating proteins.

KEYWORDS: isoflavones, proteins, soy protein isolate, production 


\section{ÍNDICE}

1. INTRODUÇÃO 1

1.1. Estrutura química das isoflavonas 2

1.2. Absorção e metabolismo das isoflavonas 5

1.3. Efeitos biológicos das isoflavonas 7

1.4. Proteínas da soja 10

1.5. Efeito do processamento 11

2. OBJETIVOS 15

3. MATERIAL E MÉTODOS 15

3.1. Umidade 15

3.2. Extração de proteínas a partir da farinha desengordurada de soja (FDS)

3.3. Análise de isoflavonas 16

3.3.1. Extração 16

3.3.2. Extração em fase sólida 17

3.3.3. Cromatografia líquida de alta eficiência 17

3.4. Determinação do conteúdo protéico 18

3.5. Determinação da solubilidade protéica 18

3.6. Eletroforese em condições dissociantes (SDS-PAGE) 19

3.7. Etapa de precipitação das proteínas da soja 20

3.8. Obtenção de isolado protéico de soja 20

3.9. Solubilidade das isoflavonas 23

3.10. $\boldsymbol{\beta}$-glicosidases endógenas 23

3.11. Solubilização de proteínas e isoflavonas a partir de
isolado protéico de soja (IPS) comercial

3.12. Análise dos resultados 25

4. RESULTADOS 26

4.1. Caracterização da farinha desengordurada de soja (FDS) 26

4.2. Efeito da razão farinha:água sobre a eficiência de extração das proteínas a partir da farinha desengordurada de soja $\quad 29$ 
4.3. Efeito do tempo e da temperatura sobre a eficiência de extração das isoflavonas e das proteínas em água

4.4. Efeito da força iônica sobre a eficiência de extração das isoflavonas e das proteínas

4.5. Efeito do pH sobre a eficiência de extração das isoflavonas e das proteínas

4.6. Efeito das condições de extração sobre o perfil de isoflavonas

4.7. Etapa de precipitação das proteínas da soja

4.8. Obtenção do isolado protéico de soja com teor aumentado de isoflavonas

4.9. Solubilidade das isoflavonas

4.10. Ação das $\beta$-glicosidases endógenas

4.11. Estudo da interação entre isoflavonas e proteínas

4.12. Proteínas da soja: fração 75 e $11 S$

5. CONCLUSÕES

6. REFERÊNCIAS BIBLIOGRÁFICAS 


\section{ÍNDICE DE TABELAS}

TABELA 1 Parâmetros modificados durante as etapas de processamento na obtenção dos isolados protéicos de soja

TABELA 2 Teores de umidade, proteínas e isoflavonas da farinha desengordurada de soja

TABELA 3 Perfil de isoflavonas extraídas a partir da farinha desengordurada de soja, em $\mathrm{MeOH} 80 \%$

TABELA 4 Perfil de isoflavonas extraídas a partir da farinha desengordurada de soja em diferentes temperaturas

TABELA 5 Perfil de isoflavonas extraídas a partir da farinha desengordurada de soja em diferentes forças iônicas

TABELA 6 Perfil de isoflavonas extraídas a partir da farinha desengordurada de soja em diferentes $\mathrm{pH}$

TABELA 7 Recuperação de isoflavonas e proteínas nos precipitados isoelétricos em $\mathrm{pH} 4,4,5$ e 5 a partir do extrato aquoso $(\mathrm{pH} \mathrm{7)}$ da farinha desengordurada de soja

TABELA 8 Razão das isoflavonas e proteínas precipitadas no $\mathrm{pH}$ 4, 4,5 e 5 a partir da solução aquosa da farinha desengordurada de soja

TABELA 9 Teores de umidade, proteínas e isoflavonas dos isolados protéicos de soja liofilizados

TABELA 10 Rendimento das etapas de obtenção dos isolados I, II e III (extração $\mathrm{pH} 7$ à temperatura ambiente, variando-se o pH de precipitação), a partir de $100 \mathrm{~g}$ de farinha desengordurada de soja

TABELA 11 Rendimento das etapas de obtenção dos isolados IV e V (extração $\mathrm{pH} 7$ à temperatura ambiente, variando-se as condições de centrifugação), a partir de $100 \mathrm{~g}$ de farinha desengordurada de soja 
TABELA 12 Rendimento das etapas de obtenção dos isolados VI (extração pH 9 à temperatura ambiente), a partir de $100 \mathrm{~g}$ de farinha desengordurada de soja

TABELA 13 Rendimento das etapas de obtenção dos isolados VII (extração $\mathrm{pH} 9$ a $55^{\circ} \mathrm{C}$ ), a partir de $100 \mathrm{~g}$ de farinha desengordurada de soja

TABELA 14 Perfil da solubilidade das isoflavonas a partir da farinha desengordurada de soja em diferentes $\mathrm{pH}$

TABELA 15 Perfil das isoflavonas extraídas a partir da farinha desengordurada de soja em tampão fosfato-citrato $\mathrm{pH} 5$ a $45{ }^{\circ} \mathrm{C}$ e a $60{ }^{\circ} \mathrm{C}$, na presença ou ausência do substrato $p$-NPG, por 3 horas

TABELA 16 Perfil das isoflavonas extraídas a partir da farinha desengordurada de soja em tampão fosfato-citrato $\mathrm{pH} 7$ na presença e na ausência de imidazol $10 \mathrm{mM}$ a $45{ }^{\circ} \mathrm{C}$, por 1 hora

TABELA 17 Perfil das isoflavonas extraídas a partir da farinha desengordurada de soja em tampão fosfato-citrato $\mathrm{pH} 5$ a $45{ }^{\circ} \mathrm{C}$, em solução aquosa pH 7 a, $45{ }^{\circ} \mathrm{C}$ em solução aquosa pH 7 à temperatura ambiente, e em solução aquosa $\mathrm{pH} 9$ a $55^{\circ} \mathrm{C}$, por 24 horas

TABELA 18 Teores de umidade, proteínas e isoflavonas do isolado protéico de soja comercial

TABELA 19 Perfil das isoflavonas extraídas a partir do isolado protéico de soja comercial em $\mathrm{MeOH} 80 \%$

TABELA 20 Solubilização de isoflavonas e proteínas a partir de isolado protéico de soja em água, em diferentes $\mathrm{pH}$, concentrações de $\mathrm{NaCl}, \beta-\mathrm{ME}$, SDS e Triton X-100

TABELA 21 Perfil das isoflavonas extraídas a partir de isolado protéico de soja comercial em soluções aquosas com $\mathrm{pH} 2$ a 10

TABELA 22 Perfil das isoflavonas extraídas a partir de isolado protéico de soja comercial em água e solução de $\mathrm{NaCl}$ a 0,05 M, 0,2 M e 0,5M 
TABELA 23 Perfil das isoflavonas do isolado protéico de soja comercial em SDS $0,1 \%$ e $1 \%$, Triton $X-100$ 0,1\%, $0,5 \%$ e $1 \%$, e $\beta$-ME 0,001M, 0,01M, 0,02M e 0,2M, no estudo da interação

TABELA 24 Teor de isoflavonas livres e associadas presentes no isolado protéico de soja comercial

TABELA 25 Análise densitométrica do perfil eletroforético das frações $7 \mathrm{~S}$ e $11 \mathrm{~S}$ extraídas a partir da farinha desengordurada de soja em solução aquosa a $4{ }^{\circ} \mathrm{C}$, $25{ }^{\circ} \mathrm{C} .50{ }^{\circ} \mathrm{C}$, em solução de $\mathrm{NaCl} 0,01 \mathrm{M}, 0,1 \mathrm{M}, 0,2 \mathrm{M}$, $0,5 \mathrm{M}$ e $1,0 \mathrm{M}$, e em solução aquosa $\mathrm{pH} 7$

TABELA 26 Análise densitométrica do perfil eletroforético das frações $7 \mathrm{~S}$ e $11 \mathrm{~S}$ extraídas a partir da farinha desengordurada de soja em solução aquosa $\mathrm{pH} 2$ a 10

TABELA 27 Análise densitométrica do perfil eletroforético das frações $7 S$ e $11 S$ solubilizadas a partir do isolado protéico de soja comercial nas seguintes soluções: água, solução aquosa pH 2 a 10, Triton X-100 0,5\%, $0,1 \%$ e $1,0 \%, \beta$-ME 0,001M, 0,01M, 0,02M e 0,2M, SDS $0,1 \%$ e $1 \%, \mathrm{NaCl} 0,05 \mathrm{M}, 0,2 \mathrm{M}$ e $0,5 \mathrm{M}$

TABELA 28 Análise densitométrica do perfil eletroforético das frações 75 e $11 \mathrm{~S}$ extraídas a partir da farinha desengordurada de soja nas etapas de obtenção do isolado (laboratório), e do isolado comercial 


\section{ÍNDICE DE FIGURAS}

FIGURA 1 Estrutura geral da isoflavona e do estradiol 2

FIGURA 2 Estruturas das isoflavonas da soja 4

FIGURA 3 Esquema de obtenção do isolado protéico de soja no laboratório (esquerda) e na indústria (direita)

FIGURA 4 Cromatograma obtido por CLAE da farinha desengordurada de soja. Solvente $A$ : ácido acético $0,1 \%$ em água; solvente $B$ : ácido acético $0,1 \%$ em acetonitrila. A fase móvel consistiu em gradiente linear de acetonitrila em fluxo de $1 \mathrm{~mL} / \mathrm{min}$

FIGURA 5 Rendimento da extração das proteínas da farinha desengordurada de soja em água na razão 1:10, 1:20 e $1: 30(\mathrm{~m} / \mathrm{v})$

FIGURA 6 Efeito do tempo e da temperatura na extração de proteínas e isoflavonas a partir da farinha desengordurada de soja

FIGURA 7 Efeito da força iônica sobre a extração de proteínas e isoflavonas a partir da farinha desengordurada de soja

FIGURA 8 Efeito do pH sobre a extração de proteínas e isoflavonas a partir da farinha desengordurada de soja

FIGURA 9 Perfil da distribuição de isoflavonas nas etapas de obtenção dos isolados I, II, III, IV e V

FIGURA 10 Perfil da distribuição de isoflavonas nas etapas de obtenção dos isolados VI e VII

FIGURA 11 Perfil da distribuição das formas totais das isoflavonas (daidzeína, genisteína e gliciteína) nas etapas de obtenção dos isolados I, II, III, IV e V

FIGURA 12 Perfil da distribuição das formas totais das isoflavonas (daidzeína, genisteína e gliciteína) nas etapas de obtenção dos isolados VI e VII

FIGURA 13 Solubilidade das isoflavonas a partir da farinha desengordurada de soja em diferentes $\mathrm{pH}$

FIGURA 14 Formação de $p$-nitrofenol a partir da farinha desengordurada de soja extraída em tampão fosfatocitrato $\mathrm{pH} 5$, contendo $0,5 \mathrm{mM}$ p-NPG, a $45^{\circ} \mathrm{C}$ e a $60{ }^{\circ} \mathrm{C}$ 
FIGURA 15 Cromatograma obtido por CLAE do isolado protéico de soja comercial. Solvente $A$ : ácido acético $0,1 \%$ em água; solvente $\mathrm{B}$ : ácido acético $0,1 \%$ em acetonitrila. A fase móvel consistiu em gradiente linear de acetonitrila em fluxo de $1 \mathrm{~mL} / \mathrm{min}$

FIGURA 16 Extração de isoflavonas (\%) por soluções aquosas em diferentes $\mathrm{pH}$ a partir da farinha desengordurada de soja e do isolado protéico de soja comercial

FIGURA 17 Extração de proteínas (\%) por soluções aquosas em diferentes $\mathrm{pH}$ a partir da farinha desengordurada de soja e do isolado protéico de soja comercial (micro-Kjeldahl)

FIGURA 18 Rendimento protéico a partir da farinha desengordurada de soja determinado através dos métodos de Lowry e de micro-Kjeldahl

FIGURA 19 Perfil eletroforético dos extratos aquosos de farinha desengordurada de soja obtidos através de SDS-PAGE $12 \%$, em diferentes temperaturas e concentrações de $\mathrm{NaCl}$

FIGURA 20 Perfil eletroforético dos extratos aquosos de farinha desengordurada de soja obtidos através de SDS-PAGE $12 \%$, em diferentes $\mathrm{pH}$

FIGURA 21 Perfil eletroforético dos extratos aquosos de farinha desengordurada de soja obtidos através SDS-PAGE 12 $\%$, em $\mathrm{pH}$ 7, em $\mathrm{pH} 4$, em $\mathrm{pH}$ 4,5 e em pH 5

FIGURA 22 Perfil eletroforético (SDS-PAGE $12 \%$ ) das proteínas presentes nas diversas etapas de obtenção dos isolados protéicos de soja

FIGURA 23 Perfil eletroforético (SDS-PAGE $12 \%$ ) das proteínas solubilizadas a partir do isolado protéico de soja em solução aquosa em diferentes $\mathrm{pH}$

FIGURA 24 Perfil eletroforético (SDS-PAGE $12 \%$ ) das proteínas solubilizadas a partir do isolado protéico de soja, em diferentes soluções

FIGURA 25 Perfil eletroforético (SDS-PAGE $12 \%$ ) das proteínas solubilizadas a partir do isolado protéico de soja, em água e em diferentes concentrações de $\mathrm{NaCl}$ 


\section{ABREVIAÇÕES}

ATP - trifosfato de adenosina

CLAE - Cromatografia Líquida de Alta Eficiência

DAD - (Diode Array Detector) detetor com arranjo de diodo

FDS - Farinha desengordurada de soja

$\mathbf{H C l}$ - Ácido clorídrico

HPLC - High-Performance Liquid Chromatographic

IPS - Isolado protéico de soja

kDa - kilo Dalton

LDL - lipoproteína de baixa densidade

MeOH - metanol

$\mathrm{NaCl}$ - cloreto de sódio

NaOH - hidróxido de sódio

ODMA - O-dimetilangolensina

PA - poliamida

PAGE - (polyacrylamide gel electrophoresis) eletroforese em gel de poliacrilamida.

pI - ponto isoelétrico

PTFE - politetrafluoroetileno

SDS - (sodium dodecyl sulfate) dodecil sulfato de sódio.

$\beta$-ME - beta-mercaptoetanol

p-NPG - $p$-nitrofenol- $\beta$-D-glucopiranosídeo 


\section{INTRODUÇÃO}

Tem-se observado no mundo inteiro a tendência ao uso de alimentos funcionais com a possibilidade de atuação na área da nutrição e saúde. Em geral, o termo funcional refere-se a alimentos e bebidas que apresentem benefícios à saúde, além da nutrição básica inerente (Hollingsworth, 1995).

A soja é hoje o alimento que oferece maiores possibilidades para o desenvolvimento de produtos funcionais no Brasil, onde já existem algumas resoluções do Ministério da Saúde, através da Agência Nacional de Vigilância Sanitária, especificando que alimentos funcionais não podem ter indicação terapêutica, prometer cura ou prevenção de doenças (BRASIL, 1999).

A soja possui em sua composição cerca de $20 \%$ de óleo, $35 \%$ de carboidratos, $5 \%$ de cinzas, $40 \%$ de proteínas, incluindo as proteínas bioativas como $\beta$-amilase, citocromo c, lectina, lipoxigenase, urease e os inibidores de tripsina, Kunitz e BowmanKirk (Friedman \& Brandon, 2001; Erickson, 1995). Possui ainda metabólitos secundários, como as isoflavonas, também chamadas fitoestrógenos, por se referir a compostos que exercem uma ação estrogênica fraca. As isoflavonas possuem entre $10^{-4}$ a $10^{-3}$ da atividade do $17 \beta$-estradiol em base molecular (Liu, 1997).

O alto conteúdo protéico de bom valor nutricional da soja, aliado ao seu baixo custo de produção e à alta produtividade, justifica o interesse no aumento do seu consumo pela população humana. A proteína da soja possui uma das melhores composições de aminoácidos essenciais entre as proteínas de origem vegetal, com exceção dos aminoácidos sulfurados, os quais são limitantes na proteína, sendo comparáveis às proteínas de alta qualidade de origem animal. Além disso, o seu alto conteúdo de lisina possibilita 
a suplementação e complementação das proteínas dos cereais (Bressani, 1981).

As proteínas da soja estão ainda associadas à redução do risco de doenças cardiovasculares através da redução dos níveis de LDL-colesterol sangüíneo. Assim, a partir das evidências científicas, Food and Drug Administration (FDA) aprovou a alegação referente à diminuição de risco de doenças cardiovasculares associada ao consumo de $25 \mathrm{~g}$ de proteína de soja por dia (FDA, 1999).

Alguns estudos indicam que as isoflavonas seriam as responsáveis pelos efeitos clínicos da soja. Entre estes, Crouse et al. (1999) demonstraram que as proteínas isoladas de soja diminuíram os níveis de LDL-colesterol em seres humanos de forma proporcional ao seu conteúdo de isoflavonas.

\subsection{Estrutura química das isoflavonas}

A estrutura química das isoflavonas é muito semelhante à do estrógeno $17 \beta$-estradiol (Figura 1), e as características que conferem a similaridade entre esses compostos são a presença do anel fenólico, pré-requisito na ligação ao receptor, 0 peso molecular semelhante, e a distância equivalente $(11,5 \AA)$ entre as hidroxilas 4' e 7 (Dixon \& Ferreira, 2002; Song et al., 1999; Hutchins et al., 1995; Cassidy et al., 2000).

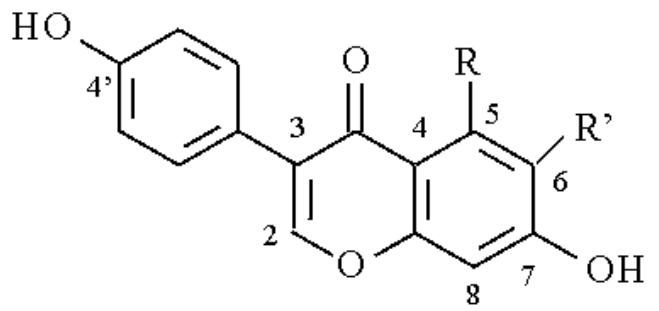

isoflavona

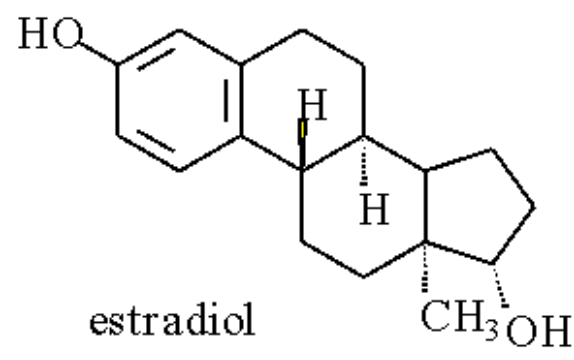

estradiol

Figura 1. Estrutura geral da isoflavona e do estradiol. 
A soja possui três isoflavonas, que se apresentam em 4 formas químicas, somando assim 12 isômeros: as agliconas daidzeína, genisteína e gliciteína; os $\beta$-glicosídeos daidzina, genistina e glicitina; e os derivados glicosilados acetilados 6 ' '-Oacetildaidzina, 6“-O-acetilgenistina, 6”-O-acetilglicitina; e glicosilados malonilados 6 ”-O-malonildaidzina, 6 ”-Omalonilgenistina e 6"-O- malonilglicitina (Wang et al., 1998, Kudou et al., 1991; Grün et al., 2001, Wang \& Murphy, 1994a,b) (Figura 2). 
Agliconas:<smiles></smiles>

genisteína<smiles></smiles>
daidzeína<smiles>COc1cc2c(=O)c(-c3ccc(O)cc3)coc2cc1O</smiles>

gliciteína

Glicosiladas:

$\beta$-glicosídeos

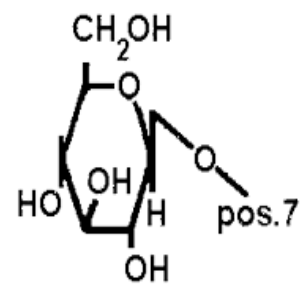

acetilglicosídeos

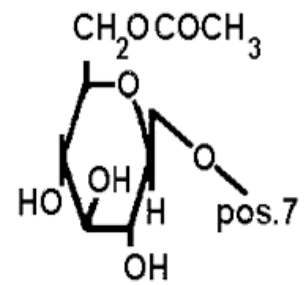

malonilglicosídeos

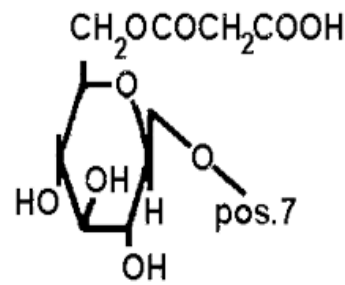

Figura 2. Estruturas das isoflavonas da soja. 
A estrutura química das isoflavonas pode influenciar a atividade biológica, biodisponibilidade, e portanto o efeito fisiológico desses constituintes (Setchell \& Cassidy, 1999).

\subsection{Absorção e metabolismo das isoflavonas}

Após a ingestão, as isoflavonas da soja são hidrolisadas pelas glicosidases intestinais (Xu et al., 1995; Izumi et al. 2000), liberando as agliconas, daidzeína, genisteína e gliciteína, que podem ser excretadas ou absorvidas e posteriormente metabolizadas em vários metabólitos específicos. A daidzeína é convertida nos seguintes metabólitos: equol, dehidrodaidzeína e O-dimetilangolensina (ODMA), e a genisteína é convertida no composto inativo $p$-etilfenol (Setchell et al., 1984; Hutchins et al., 1995; Setchell \& Cassidy, 1999). Porém, pouco se conhece sobre o metabolismo da gliciteína, já que ela ocorre numa proporção muito inferior à da genisteína e daidzeína (Kulling et al., 2001). A extensão deste metabolismo é altamente variável entre indivíduos e é influenciada pela flora intestinal e por outros componentes da dieta (Cassidy et al., 2000).

Assim como os estrógenos endógenos, as isoflavonas apresentam uma circulação enterohepática, e são secretadas na bile (Kurzer \& Xu, 1997).

A absorção tem lugar em todo o intestino, possivelmente por difusão passiva não-iônica, e a conjugação das isoflavonas ao ácido glicurônico se dá principalmente no fígado e também ocasionalmente no intestino, durante a fase de absorção (Setchell et al., 2002).

As isoflavonas estão presentes na urina e no plasma, em geral sob a forma de glicuronídeos conjugados ( $90 \%$ ), e apenas 3-5 \% como sulfatos (Aldercreutz et al., 1995). A eliminação 
ocorre via renal, principalmente como glicuronídeos conjugados (Kulling et al., 2001).

Izumi et al. (2000) observaram que a forma aglicona foi mais rapidamente absorvida que a glicosídica, que é mais hidrofílica e com maior peso molecular, e atribuíram esta diferença ao fato de que as formas glicosiladas precisam ser previamente hidrolisadas para serem absorvidas.

Ainda, a biodisponibilidade das isoflavonas pode ser influenciada pela forma de consumo da soja. Os produtos de soja fermentados (missô, natto e tempeh) apresentaram como forma principal as agliconas, enquanto os não-fermentados (soja e seus derivados, farinha, isolado protéico, concentrado protéico) apresentaram como forma principal os glicosídeos (Wang \& Murphy, 1994a). A hidrólise dos produtos fermentados pode ser devida às $\beta$-glicosidases fúngicas (Wang \& Murphy, 1996; Nakamura et al., 2000). Assim, Hutchins et al. (1995) relataram que os alimentos fermentados apresentavam isoflavonas mais biodisponíveis que os não-fermentados.

A eficácia clínica das isoflavonas está supostamente ligada à concentração plasmática, e a relação entre ingestão, metabolismo, absorção e efeito biológico representa uma área de pesquisa crescente. $O$ interesse nas isoflavonas como componente benéfico da dieta tem dirigido a atenção para a população ocidental, levando as pessoas a aumentarem o consumo de soja e seus derivados.

As propriedades biológicas associadas com os fitoestrógenos causaram um aumento nas pesquisas sobre seu potencial na prevenção e/ou tratamento das doenças hormônio-dependentes.

A dose ideal de isoflavonas requerida para se ter efeitos clínicos ainda está para ser estabelecida. Porém, alguns estudos indicam que cerca de $50 \mathrm{mg} /$ dia de agliconas sejam suficientes 
para se ter efeitos clínicos/biológicos (Cotter, 2003; Somekawa et al., 2001; Setchell, 1998; Bingham et al., 1998).

\subsection{Efeitos biológicos das isoflavonas}

Vários estudos in vitro, em modelos animais, em seres humanos, e epidemiológicos vêm evidenciando os efeitos biológicos das isoflavonas, entre eles, anticarcinogênico, antioxidante, hipocolesterolêmico, prevenção de osteoporose, doenças cardiovasculares e melhora dos sintomas da menopausa.

A atividade antioxidante das isoflavonas foi demonstrada em sistema in vitro e observou-se que $\mathrm{o}$ equol $\mathrm{e}$ a $\mathrm{O}$ dimetilangolensina inibem a oxidação da LDL, em concentrações de $0,1 \mu \mathrm{M}$, prováveis de serem atingidas com o consumo moderado de produtos de soja. A genisteína e a daidzeína também inibiram a oxidação só que em maiores concentrações (1 $\mu \mathrm{M}$ ) (Hodgson et al., 1996). Já Pratt \& Birac (1979) demonstraram que a soja e seus derivados (farinha desengordurada, concentrado protéico e isolado protéico) possuíam atividade antioxidante, avaliada através da porcentagem de descoloração do $\beta$-caroteno.

Os fitoestrógenos encontrados na soja podem reduzir o risco de cânceres hormônio-dependentes e não-dependentes, tais como de pulmão, cólon, reto, estômago, mama e próstata. Assim, observou-se uma relação direta entre concentração de fitoestrógeno no plasma e na urina de mulheres japonesas, que consomem uma dieta tradicional, e a baixa incidência de câncer de mama, endométrio e ovário neste grupo (Adlercreutz et al., 1991; Setchell \& Cassidy, 1999).

A genisteína inibiu a proliferação de células normais e cancerosas, provavelmente através da inibição de uma ou mais 
enzimas envolvidas na transdução de sinal, incluindo tirosina quinase (Akiyama et al., 1987), quinase S6 ribossomal, quinase MAP, DNA topoisomerase II (Thorburn et al., 1994; Linassier et al., 1990; Liu, 1997). Estas enzimas atuam na regulação e controle do crescimento celular.

A redução do estrógeno endógeno leva a uma série de mudanças fisiológicas que resultam em sintomas como ondas de calor, vaginite atrófica, secura vaginal, e ainda contribui para o desenvolvimento da osteoporose e aumento do risco de doenças cardiovasculares (Kurzer \& Xu, 1997). Experiências epidemiológicas e clínicas mostraram que a terapia com estrógeno ajuda a amenizar os sintomas da menopausa. Adlercreutz et al. (1992) sugeriram que uma dieta rica em fitoestrógeno, por possuir uma ação estrogênica fraca, explicaria a menor incidência de sintomas da menopausa em mulheres japonesas.

A deficiência do estrógeno foi associada também com alterações significativas do metabolismo lipoprotéico. A redução ou prevenção do aumento do colesterol sérico leva à redução do risco de doenças cardíacas (Kurzer \& Xu, 1997; Setchell \& Cassidy, 1999). A redução de $1 \%$ do colesterol sérico reduziu em 2-3 \% o risco de doenças cardíacas (Liu, 1997; Bingham et al., 1998).

Quanto maior for o nível inicial do colesterol, maior será o efeito da proteína de soja em baixar o colesterol. Mesmo em pessoas com colesterol normal as isoflavonas da soja podem ajudar a reduzir o risco de doenças coronarianas (Setchell \& Cassidy, 1999). Carroll \& Kurowska (1995) observaram que o decréscimo do colesterol sangüíneo geralmente é maior para indivíduos hipercolesterolêmicos que normocolesterolêmicos.

Essa redução do colesterol e do risco de doenças cardiovasculares parece ocorrer pela ação das proteínas da soja, e/ou das isoflavonas, ou por outros fatores ainda desconhecidos. 
Contudo, o efeito hipocolesterolêmico foi menor quando as isoflavonas foram removidas da proteína de soja por extração alcoólica, sugerindo que os componentes ativos da soja podem ser as isoflavonas (Gardner et al., 2001).

Crouse et al. (1999) realizaram um estudo com 156 pessoas saudáveis (homens e mulheres) para identificar o(s) agente(s) responsáveis pelo efeito de diminuição do colesterol da soja, em indivíduos moderadamente hipercolesterolêmicos. As dietas diárias consistiam de $25 \mathrm{~g}$ de caseína ou $25 \mathrm{~g}$ de IPS contendo 3, 27, 37 , ou $62 \mathrm{mg}$ de isoflavonas. Os autores observaram o efeito dose-resposta das isoflavonas sobre os níveis de colesterol total e LDL. O IPS contendo $3 \mathrm{mg}$ de isoflavonas (sujeito a extração prévia com etanol) não apresentou efeito significativo sobre as concentrações plasmáticas de colesterol total e LDL.

O efeito benéfico da terapia de reposição hormonal é conhecido em relação à prevenção da osteoporose, portanto a ação estrogênica fraca das isoflavonas pode também prevenir a perda óssea (Cassidy et al., 2000).

A grande maioria dos estudos foi realizada em ratas ovariectomizadas, e Ishimi et al. (2002) observaram que a genisteína inibiu os osteoclastos, inibindo a reabsorção óssea.

Em estudos epidemiológicos, Somekawa et al. (2001) relataram uma correlação positiva entre consumo de isoflavonas (54,3 mg/dia) e densidade mineral óssea em mulheres japonesas (44 a 80 anos) na pós-menopausa, assim as mulheres que consumiam mais isoflavonas tinham alta densidade mineral óssea e menor incidência de osteoporose. Potter et al. (1998) observaram um aumento significativo na densidade mineral óssea na coluna lombar em mulheres na pós-menopausa e hipercolesterolêmicas que consumiram proteína de soja com alta concentração de 
isoflavonas comparadas com o grupo com teor reduzido de isoflavonas.

\subsection{Proteínas da soja}

As proteínas da soja são conhecidas por sua heterogeneidade e podem ser classificadas quanto à solubilidade como globulinas, tendo como característica serem insolúveis em água em seu ponto isoelétrico ( $\mathrm{pI})$, mas solúveis em soluções salinas diluídas ou água em valores de $\mathrm{pH}$ acima ou abaixo de seu pI. As proteínas de soja também podem ser classificadas de acordo com seu comportamento na ultracentrifugação em tampão fosfato $\mathrm{pH} 7,6$ e força iônica 0,5. A análise das proteínas extraídas em água a partir da farinha desengordurada de soja revela quatro frações conhecidas como 2S, 7S, 11 S e 15S, baseado em seus coeficientes de sedimentação (S 20,a) (Wolf, 1970; Wolf \& Cowan, 1971). As duas principais proteínas de reserva encontradas na soja são $7 \mathrm{~S}$ ( $\beta$-conglicinina) e a 11 S (glicinina) (Thanh \& Shibasaki, 1976; Liu, 1997), e estas corresponderam a quase a totalidade das proteínas presentes nos isolados protéicos.

A $\beta$-conglicinina é a principal proteína da fração 7S, e corresponde a um trímero com 3 tipos principais de subunidades $(\alpha, \alpha$ e $\beta$ ) e uma subunidade menor $(\gamma)$, com P.M. de $57.000 \mathrm{Da}$ para as subunidades $\alpha$ e $\alpha^{\prime}$, e 42.000 Da para as subunidades $\beta$ e $\gamma$ (Thanh \& Shibasaki, 1977).

A $\beta$-conglicinina é heterogênea em relação à composição de subunidades, sendo encontrada em seis diferentes estruturas isômeras: $B_{1}\left(\alpha^{`} \beta \beta\right) ; B_{2}(\alpha \beta \beta) ; B_{3}\left(\alpha \alpha^{\prime} \beta\right) ; B_{4}(\alpha \alpha \beta) ; B_{5}$ $\left(\alpha \alpha \alpha^{\prime}\right)$ e $B_{6}(\alpha \alpha \alpha)$ (Thanh \& Shibasaki, 1978).

A $\beta$-conglicinina sofre um complicado fenômeno de associação-dissociação em resposta às mudanças do $\mathrm{pH}$ e força 
iônica. Os seis isômeros são capazes de dimerizar reversivelmente em baixa força iônica ou na região de $\mathrm{pH}$ de 4,8 a 11. A forma resultante 9S é um superdímero de 2 trímeros um à frente do outro, formando um hexâmero (Thanh \& Shibasaki, 1979).

A glicinina corresponde à globulina 11S. O modelo aceito da glicinina é um hexâmero com P.M. de 360 KDa (Iyengar \& Ravestein, 1981), com doze unidades, sendo seis ácidas (P.M. 34.800 Da) e seis básicas (P.M. 19.600 Da), e das 6 subunidades ácidas, a subunidade A4 apresentam peptídeos maiores, ao redor de $45.000 \mathrm{Da}$. As subunidades ácidas (A) e básicas (B) se alternam formando anéis com seis subunidades. Os dois anéis (hexâmero) se combinariam superpondo-se um ao outro através de interações eletrostáticas e/ou pontes de hidrogênio (Badley et al., 1975).

A estrutura quaternária da glicinina é rompida através de calor, altas concentrações de uréia ou detergentes e pH alto ou baixo. Em baixa força iônica $(0,01)$ a glicinina se dissocia parcialmente em componentes 2 a $3 S$ (provavelmente as subunidades "intermediárias") e 7S (meia-molécula de glicinina) (Wolf \& Cowan, 1971).

\subsection{Efeito do processamento}

A concentração de isoflavonas na soja e seus derivados pode variar muito, pois depende da variedade do grão, solo, clima, local onde foi cultivada e principalmente do tipo de processamento utilizado no preparo dos produtos protéicos (Lee et al., 2003).

As condições de processamento da soja podem provocar alterações no teor total e no perfil de isoflavonas presentes, assim como nas frações protéicas. A maioria das isoflavonas em soja e derivados protéicos como farinha desengordurada, isolados, 
concentrados e proteína texturizada encontra-se na forma esterificada (97-98 \%). A distribuição entre essas formas, no entanto, varia de produto para produto (Wang \& Murphy, 1994b).

O termo derivado protéico de soja refere-se aos derivados processados a partir do resíduo resultante da extração do óleo. As combinações de opções para produzir os diversos produtos são ilimitadas.

A farinha de soja é obtida na forma integral ou desengordurada e estas podem ser tostadas ou extrusadas. O processo de desengorduramento não afeta o teor e perfil das isoflavonas (Eldridge \& Kwolek, 1983), porém afeta a solubilidade protéica por provocar desnaturação das proteínas (Visser \& Thomas, 1987). A utilização de calor na obtenção da farinha tostada ou extrusada causa mudança no perfil das isoflavonas (Coward et al., 1993). Porém, o calor oferece a vantagem de aumentar o valor nutricional, por inativar fatores antinutricionais, aumentar a digestibilidade protéica, e reduzir o "off-flavor" (Visser \& Thomas, 1987).

O concentrado protéico de soja é produzido a partir da farinha de soja, e apresenta no conteúdo total cerca de $70 \%$ de proteínas. Há dois processos para obtenção dos concentrados, extração alcóolica ou em solução aquosa a pH 4,5 podendo ou não ser realizados à quente (Erickson, 1995).

Esses tratamentos afetam tanto o conteúdo de isoflavonas, obtendo-se um teor reduzido quando a extração é realizada em solução alcoólica, quanto as propriedades funcionais das proteínas, como por exemplo, na extração com aquecimento brando, onde há uma pequena desnaturação protéica, nota-se um aumento da solubilidade (Visser \& Thomas, 1987).

Em relação aos isolados protéicos de soja existem várias opções de processamento, sendo que a tecnologia empregada no 
processo de obtenção permite o desenvolvimento de funcionalidade específica, otimizada para cada uma das aplicações recomendadas, tais como, suplementos alimentares, panificação, produtos nãolácteos, entre outros.

O isolado é a forma mais refinada entre os derivados protéicos, contém mais de $90 \%$ de proteína, e é preparado a partir do processo de extração aquosa da farinha em pH alcalino, sendo removidas as fibras (frações não-protéicas insolúveis) e após precipitação no ponto isoelétrico das proteínas, os açúcares (solúveis em água). O precipitado é lavado com água e seco por atomização, resultando no isolado isoelétrico, ou pode ser ainda neutralizado com hidróxido de sódio ou potássio antes da secagem, formando o proteinato de sódio ou potássio. Os proteinatos apresentam a vantagem de uma maior dispersibilidade em água que os isolados isoelétricos, que são insolúveis em água (Wolf, 1970).

Os isolados protéicos de soja contêm teores reduzidos de isoflavonas em relação à farinha e ao grão de soja, como resultado da extração aquosa usada no seu processamento (Anderson \& Wolf, 1995). Em relação ao perfil, as agliconas apresentaram-se em maior concentração que os glicosídeos desesterificados, e o processamento de secagem do isolado usando-se "spray-drying" leva a uma maior proporção de acetilglicosídeos e decréscimo de malonilglicosídeos, como resultado do aquecimento. Porém isso não se observa quando se utiliza a liofilização (Wang \& Murphy, 1996; Wang \& Murphy, 1994a).

A farinha de soja desengordurada é muito utilizada no enriquecimento protéico de pães, bolachas, tortas e outros tipos de alimentos de confeitaria. Pelas suas características funcionais, o isolado protéico de soja é muito utilizado no processamento de suplementos alimentares (misturas em pó), bebidas prontas para 
consumo, panificação, produtos cárneos, tais como salsichas, lingüiças, mortadelas, almôndegas, quibes e hambúrgueres; e também são os mais adequados para adição acima de $10 \%$ em produtos cárneos, já que adição de farinha e concentrados protéicos gera problemas relacionados com a textura e com o aroma dos produtos (Kinsella, 1979).

A utilização de isolado protéico de soja está aumentando e produtos novos vêm sendo desenvolvidos, juntamente com as pesquisas crescentes no campo das isoflavonas, o que justifica a realização de estudos visando um maior aproveitamento nas etapas de processamento, diminuindo as perdas das isoflavonas e conservando o conteúdo protéico.

Desta maneira, novos produtos alimentícios são gerados através do avanço dos conhecimentos científicos, relacionando dieta e saúde, aliados também aos custos da saúde pública e aos interesses econômicos da indústria. Atualmente, existe a preocupação em incorporar ingredientes que possuam propriedades capazes de proporcionar efeitos benéficos. Assim, a sociedade, o consumidor, a comunidade científica, os órgãos reguladores e a mídia estão demonstrando maior interesse na relação saúde e hábitos alimentares (Arabbi, 2001). 


\section{OBJETIVOS}

> Otimizar as condições de extração das isoflavonas e de suas formas conjugadas a partir da farinha desengordurada de soja, visando o preparo de isolado protéico de soja com alto teor de isoflavonas.

> Determinar os fatores que influenciam o teor e perfil de isoflavonas de isolados protéicos de soja.

\section{MATERIAL E MÉTODOS}

Todos os reagentes utilizados foram de grau analítico, ou grau cromatográfico (HPLC) quando necessário. A poliamida em pó utilizada na extração em fase sólida foi obtida da Macherey-Nagel (Polyamide CC6, $\mathrm{n}^{\circ}$ catálogo 815.620). As amostras de farinhas desengorduradas de soja e isolados protéicos de soja foram fornecidos pela BUNGE ALIMENTOS S.A. (Esteio, Rio Grande do Sul). Após o recebimento, a farinha desengordura de soja (FDS) e o isolado protéico de soja (IPS) comercial foram armazenados no freezer $\left(-18^{\circ} \mathrm{C}\right)$, durante todo o período de estudo.

\subsection{Umidade}

A umidade da FDS e do IPS comercial foi determinada por dessecação em estufa a $105^{\circ} \mathrm{C}$ até peso constante (AOAC, 1995). As análises foram realizadas em triplicata. 


\subsection{Extração de proteínas a partir da farinha desengordurada de soja (FDS)}

A FDS foi extraída com agitador mecânico e barra magnética, em meio aquoso. Foram avaliados os seguintes parâmetros: razão farinha:solução extratora, tempo e temperatura de extração, e pH e força iônica da solução extratora sobre o rendimento de proteínas e isoflavonas. Os extratos obtidos foram centrifugados a $11.951 \mathrm{~g}$ por 30 min $\left(4^{\circ} \mathrm{C}\right)$, e o sobrenadante utilizado para a determinação do teor protéico, perfil eletroforético e isoflavonas. As extrações foram realizadas em triplicata.

\subsection{Análise de isoflavonas}

\subsubsection{Extração}

As amostras (farinhas e isolados) foram extraídas com agitador mecânico e barra magnética por 2 horas a $4{ }^{\circ} \mathrm{C}$, na proporção de $1: 20(\mathrm{~m} / \mathrm{v})$, com metanol aquoso $80 \%$, segundo Genovese \& Lajolo $(2001 a, b)$. Os extratos obtidos foram filtrados utilizando-se papel de filtro Whatman $n^{\circ} 6$. Para concentração dos extratos foi utilizado rotaevaporador (Rotavapor ${ }^{\circledR}$ RE 120 - Büchi, Flawil, Suíça), em temperatura de banho de $40{ }^{\circ} \mathrm{C}$. As amostras foram concentradas até eliminação do metanol e transferidas para balão volumétrico. Foi adicionado metanol (grau cromatográfico) para correção do volume, de forma a se obter concentração final de cerca de $80 \%$ de metanol, e os extratos foram então filtrados utilizando-se filtros de polietileno com membrana de politetrafluoroetileno (PTFE), de 0,22 $\mu \mathrm{m}$ de poro (Millipore Ltd., Bedford, E.U.A.) para posterior análise por CLAE. As extrações foram realizadas em triplicata. 


\subsubsection{Extração em fase sólida}

Os extratos obtidos em 3.2 foram passados em coluna de $1 \mathrm{~g}$ de poliamida (PA) previamente condicionada pela passagem de $20 \mathrm{~mL}$ de metanol seguidos por $60 \mathrm{~mL}$ de água destilada. A coluna foi então lavada com $20 \mathrm{~mL}$ de água destilada e as isoflavonas posteriormente eluídas com $50 \mathrm{~mL}$ de metanol:amônia 99,5:0,5, segundo Genovese \& Lajolo (2001a). Foi utilizado manifold Visiprep 24 DL da Supelco (Bellefonte, E.U.A.). Os eluatos foram evaporados sob vácuo a $40{ }^{\circ} \mathrm{C}$ até atingir o volume de $0,8 \mathrm{~mL}$. As amostras foram transferidas para balão volumétrico e o volume completado com metanol (grau cromatográfico) para $2 \mathrm{~mL}$. As amostras foram então filtradas utilizando-se filtros de polietileno com membrana (PTFE) de 0,22 $\mu \mathrm{m}$ de poro para análise por CLAE.

Os extratos aquosos em $\mathrm{pH}$ alcalino (maior que $\mathrm{pH} 7$ ) tiveram $\circ \mathrm{pH}$ acertado para a neutralidade antes de serem passados pela coluna de poliamida, já que observou-se que não havia ligação dos malonilglicosídeos em pH alcalino.

\subsubsection{Cromatografia líquida de alta eficiência}

A separação e quantificação das isoflavonas e de suas formas conjugadas foi realizada em coluna C18 NovaPak (Waters, Milford, E.U.A.) de acordo com o método de Song et al. (1998). O cromatógrafo líquido utilizado foi o da Hewlett Packard (Palo Alto, E.U.A.) série 1100, equipado com injetor automático de amostras, bomba quaternária e detetor com arranjo de diodos (DAD), controlado pelo software ChemStation. Alíquotas de $20 \mu \mathrm{L}$ foram injetadas em fluxo de $1 \mathrm{~mL} / \mathrm{min}$, utilizando solvente $A: 0,1 \%$ ácido acético em água e solvente $\mathrm{B}: 0,1 \%$ ácido acético em acetonitrila. $O$ gradiente linear foi iniciado com $18 \%$ do solvente $B$, passando 
para $29 \%$ em 15 minutos, para $32 \%$ em 20 minutos, para $50 \%$ em 25 minutos, atingindo $60 \%$ em 26 minutos, decrescendo para $50 \%$ em 27 minutos e $18 \%$ em 35 minutos. A calibração foi realizada com os padrões de daidzeína e genisteína da Sigma Chemicals Co. (St. Louis, E.U.A.), daidzina e genistina da Apin Chemicals Ltd. (Abingdon, Reino Unido), glicitina e gliciteína da Fujicco Co. Ltd. (Kyoto, Japão), injetados em triplicata, em cinco concentrações diferentes. A identificação foi feita a partir dos tempos de retenção e dos espectros. As amostras foram injetadas em duplicata. Os resultados foram expressos como $\mathrm{mg}$ de isoflavona por $100 \mathrm{~g}$ de amostra (b.u.), após normalização das diferenças de peso molecular das formas glicosiladas, feita multiplicando-se a massa de cada derivado pela razão entre o peso molecular da respectiva aglicona e o peso molecular da forma glicosilada, conforme Song et al. (1998).

\subsection{Determinação do conteúdo protéico}

As amostras de farinha e de isolado tiveram seu conteúdo protéico determinado através do método de micro-Kjeldahl $(\mathrm{N} \times$ 6,25) (AOAC, 1995), em triplicata. O teor protéico dos extratos foi determinado pelo método de Lowry et al. (1951), usando-se albumina de soro bovino (Sigma Chemicals Co., St. Louis, E.U.A) como padrão, ou, quando indicado, pelo método de micro-Kjeldahl.

\subsection{Determinação de solubilidade protéica}

A solubilidade da FDS e do IPS comercial foi determinada a partir da extração de um grama de amostra em $20 \mathrm{~mL}$ de água destilada ou de solução extratora por 1 hora a $4{ }^{\circ} \mathrm{C}$. A suspensão 
foi então centrifugada $\left(11.951 \mathrm{~g} / 10 \mathrm{~min}\right.$ a $4{ }^{\circ} \mathrm{C}$ ) e o sobrenadante utilizado para determinação do seu teor protéico pelo método de micro-Kjeldahl ( $\mathrm{N} \times$ 6,25) (AOAC, 1995). As análises foram realizadas em triplicata. A correlação entre a proteína total da amostra e a proteína contida no sobrenadante permite o cálculo de solubilidade, através da fórmula:

Solubilidade $(\%)=P \underline{\mathrm{s}} \times 100$

$$
\mathrm{P}_{\mathrm{T}}
$$

onde:

$\mathrm{P}_{\mathrm{S}}=$ proteína contida no sobrenadante

$\mathrm{P}_{\mathrm{T}}=$ proteína total contida na amostra

\subsection{Eletroforese em condições dissociantes (SDS-PAGE)}

A eletroforese em presença de dodecil sulfato de sódio foi realizada de acordo com Laemmli (1970), utilizando-se concentração de $12 \%$ de poliacrilamida para o gel de separação. Foram aplicadas de 20 a $80 \mu \mathrm{g}$ de proteína por poço. As amostras foram preparadas utilizando-se volumes iguais $(100 \mu \mathrm{L})$ das soluções protéicas e do tampão da amostra contendo $4 \%$ de $\beta$-mercaptoetanol e $4 \%$ de SDS, e mantidas em banho-maria fervente durante 2 a 3 minutos. Após o término da corrida (voltagem constante de $200 \mathrm{~V}$, durante 50 minutos), os géis foram revelados com solução metanólica de Coomassie Blue R. Uma solução contendo $10 \%$ de etanol e $7 \%$ de ácido acético foi usada como descorante. Os padrões de peso molecular utilizados foram LMW (Amersham Biosciences), contendo $\alpha$-lactalbumina $(14,4 \mathrm{kDa})$, inibidor de tripsina de soja $(20,1 \mathrm{kDa})$, anidrase carbônica (30 kDa), ovoalbumina (43 kDa), albumina de soro bovino (67 kDa) e fosforilase $B(94 \mathrm{kDa})$. 


\subsection{Etapa de precipitação das proteínas da soja}

A fim de determinar $\mathrm{o}$ melhor $\mathrm{pH}$ de precipitação, as proteínas foram extraídas a partir de $10 \mathrm{~g}$ de FDS em $200 \mathrm{~mL}$ de água destilada $\mathrm{pH} 7$, com agitador mecânico e barra magnética, durante 1 hora a $4{ }^{\circ} \mathrm{C}$. Os extratos foram centrifugados a $11.951 \mathrm{~g} / 10 \mathrm{~min}\left(4^{\circ} \mathrm{C}\right)$ e do sobrenadante foi retirada uma alíquota para a determinação do teor protéico, perfil eletroforético e isoflavonas e o restante foi dividido em 3 alíquotas de $50 \mathrm{~mL}$ às quais adicionou-se $\mathrm{HCl} 6 \mathrm{~N}$ para precipitação protéica no $\mathrm{pH}$ 4, $\mathrm{pH} 4,5 \mathrm{e} \mathrm{pH}$ 5. As suspensões permaneceram em repouso por trinta minutos à temperatura ambiente e então foram centrifugadas $\left(11.951 \mathrm{~g} / 10 \mathrm{~min}\right.$ a $4{ }^{\circ} \mathrm{C}$ ), e o sobrenadante utilizado para a determinação do teor protéico, perfil eletroforético e isoflavonas. As análises foram realizadas em triplicata.

\subsection{Obtenção de isolado protéico de soja}

As proteínas foram extraídas em água a partir da FDS com agitador mecânico e barra magnética na proporção 1:20 (m/v) durante 1 hora. Ajustou-se a solução para pH 7 e para pH 9 com $\mathrm{NaOH} 4 \mathrm{~N}$, que foi mantido constante durante a extração, sendo que $\mathrm{o} \mathrm{pH}$ foi verificado após as extrações. O extrato foi então centrifugado ( $16.274 \mathrm{~g} / 20 \mathrm{~min}$ a $25^{\circ} \mathrm{C}$ ) e o sobrenadante (extrato total) teve seu volume medido e alíquotas retiradas para a determinação do teor protéico e de isoflavonas. A seguir, o extrato total teve seu $\mathrm{pH}$ ajustado para 4,5 por adição de $\mathrm{HCl} 6 \mathrm{~N}$. As proteínas formaram um precipitado de fácil decantação e o extrato permaneceu em repouso por trinta minutos à temperatura ambiente, após o qual foi centrifugado. Os precipitados ácidos foram lavados com água acidificada $(\mathrm{pH} 4,5)$ por 5 minutos sob 
agitação, e centrifugados novamente. O sobrenadante obtido em $\mathrm{pH} 4,5$ (soro ácido) e a água de lavagem tiveram os seus volumes medidos em proveta e alíquotas retiradas para a determinação do teor protéico e de isoflavonas. Os precipitados ácidos foram liofilizados e retirou-se uma alíquota para determinação do teor de sólidos. Os isolados protéicos obtidos após a liofilização foram armazenados no freezer para determinação do teor protéico e de isoflavonas. As extrações e as análises foram realizadas em triplicata. Foram preparados sete isolados (I a VII), e os parâmetros que foram modificados durante as etapas de processamento na obtenção dos isolados são apresentados na Tabela 1.

Tabela 1. Parâmetros modificados durante as etapas de processamento na obtenção dos isolados protéicos de soja.

pH temperatura centrifugação pH ppt centrifugação $\left({ }^{\circ} \mathrm{C}\right)$

(g)

(g)

\begin{tabular}{lccccc}
\hline Isolado I & 7 & 26 & $16.274 / 20^{\prime}$ & 4,5 & $16.274 / 20^{\prime}$ \\
Isolado II & 7 & 24 & $16.274 / 20^{\prime}$ & 4,0 & $16.274 / 20^{\prime}$ \\
Isolado III & 7 & 22 & $16.274 / 20^{\prime}$ & 4,5 & $16.274 / 20^{\prime}$ \\
Isolado IV & 7 & 26 & $16.274 / 20^{\prime}$ & 4,5 & $162 / 2^{\prime}$ \\
Isolado V & 7 & 24 & $16.274 / 20^{\prime}$ & 4,5 & $162 / 1^{\prime}$ \\
Isolado VI & 9 & 24 & $16.274 / 20^{\prime}$ & 4,5 & $162 / 2^{\prime}$ \\
Isolado VII & 9 & 55 & $16.274 / 20^{\prime}$ & 4,5 & $162 / 2^{\prime}$ \\
\hline
\end{tabular}

A Figura 3 mostra o esquema de obtenção de isolado protéico de soja no laboratório, e para efeito de comparação, na indústria. 
LABORATÓRIO

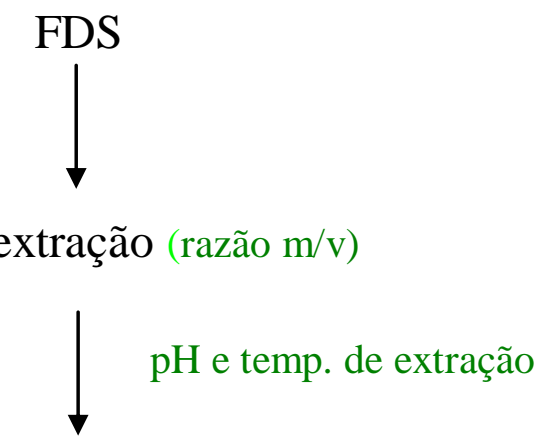

centrifugação

resíduo
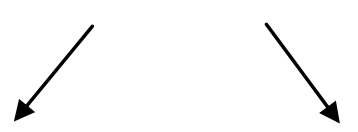

sobrenadante

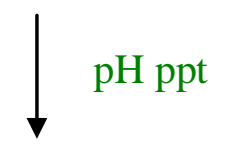

pptação proteína

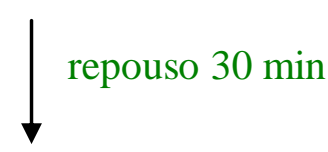

centrifugação

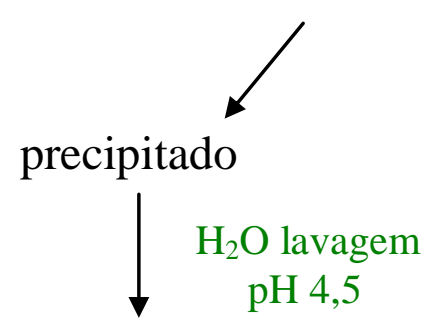

centrifugação

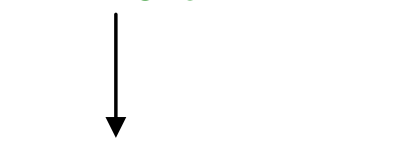

liofilização

\section{INDUSTRIAL*}

FDS

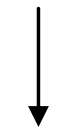

extração (1:10 ou $1: 20 \mathrm{~m} / \mathrm{v})$

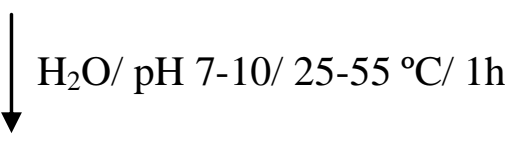

centrifugação

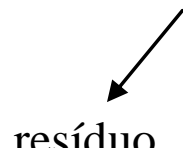

resíduo

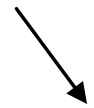

sobrenadante<smiles>C[13CH3]</smiles>

pptação proteína

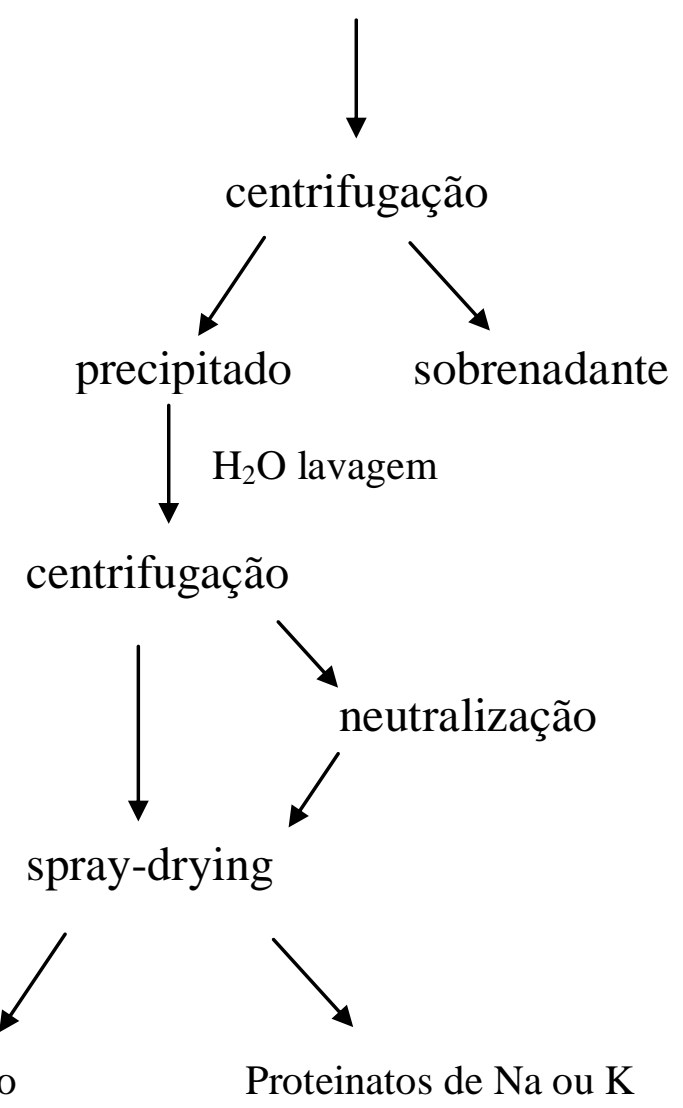

isolado isoelétrico 


\subsection{Solubilidade das isoflavonas}

As isoflavonas foram extraídas a partir da FDS conforme 3.3.1. Após eliminação do metanol, os extratos obtidos foram passados em coluna de poliamida conforme descrito no item 3.3.2. Os eluatos foram evaporados sob vácuo a $40{ }^{\circ} \mathrm{C}$ até atingir o volume de $2 \mathrm{~mL}$ (exceto para o controle, obtido conforme 3.3.2). As amostras foram transferidas para béquer, com a ajuda de água destilada, de forma a obter-se um volume final de cerca de $5 \mathrm{~mL}$. Cada amostra teve o pH ajustado para valores entre 2 e 10, ficando em repouso por 30 minutos, sendo então filtradas utilizando-se filtros de polietileno com membrana PTFE de 0,22 $\mu \mathrm{m}$ de poro para balão volumétrico, e o volume completado com metanol (grau cromatográfico) para $10 \mathrm{~mL}$. As amostras foram analisadas por CLAE. As extrações foram realizadas, para cada $\mathrm{pH}$, em duplicata.

\subsection{0. $\beta$-glicosidades endógenas}

A determinação da atividade da $\beta$-glicosidase foi realizada de acordo com Matsuura et al (1995), utilizando-se o substrato sintético $p$-nitrofenol- $\beta$-D-glucopiranosídeo ( $p$-NPG) da Sigma Chemicals Co. (St. Louis, EUA). A FDS ( $2 \mathrm{~g}$ ) foi extraída em $40 \mathrm{~mL}$ de $p$-NPG $0,5 \mathrm{mM}$ em tampão fosfato-citrato $0,1 \mathrm{M} \mathrm{pH} 5$, em banho sob agitação, em duas diferentes temperaturas. A primeira foi a $45{ }^{\circ} \mathrm{C}$, temperatura ótima da enzima, e a outra foi a $60{ }^{\circ} \mathrm{C}$, temperatura de inativação da enzima. Alíquotas de $1 \mathrm{~mL}$ foram retiradas nos seguintes tempos: $0,1,5,10,15,20,25,30,45,60$, 90 , e 120 minutos e adicionadas em tubos contendo $1 \mathrm{~mL}$ de solução de carbonato de sódio $0,625 \mathrm{M}$ e $0,25 \mathrm{~mL}$ de tampão fosfato-citrato $0,1 \mathrm{M} \mathrm{pH}$ 5. A coloração amarela, resultado da 
liberação do $p$-nitrofenol em meio alcalino, foi determinada logo a seguir a $420 \mathrm{~nm}$ em espectrofotômetro modelo Ultrospec 2000 UV/ Visible (Amersham Biosciences, Cambridge, Reino Unido). 0 aparelho foi zerado com $1,0 \mathrm{~mL}$ de $p$-NPG $0,5 \mathrm{mM}, 0,25 \mathrm{~mL}$ de tampão fosfato-citrato $0,1 \mathrm{M} \mathrm{pH} 5$ e $1 \mathrm{~mL}$ de solução de carbonato de sódio $0,625 \mathrm{M}$. O branco amostra consistiu de $1,0 \mathrm{~mL}$ do extrato

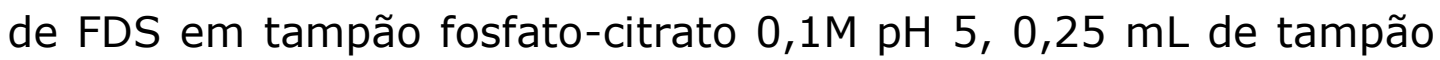
fosfato-citrato $0,1 \mathrm{M} \mathrm{pH} 5$ e $1 \mathrm{~mL}$ de solução de carbonato de sódio. A curva padrão foi preparada com 10 - $100 \mu \mathrm{L}$ da solução de p-nitrofenol 0,5 mM em tampão fosfato-citrato $0,1 \mathrm{M} \mathrm{pH} 5$.

Em paralelo, a FDS foi extraída com as seguintes soluções: (1) tampão fosfato-citrato $0,1 \mathrm{M} \mathrm{pH} \mathrm{5,} \mathrm{na} \mathrm{presença} \mathrm{ou} \mathrm{ausência} \mathrm{do}$ $p$-NPG 0,5 mM, a $45^{\circ} \mathrm{C}$ e $60^{\circ} \mathrm{C}$, por 3 horas;

(2) tampão fosfato-citrato $0,1 \mathrm{M} \mathrm{pH} 5$ a $45^{\circ} \mathrm{C}$, por 24 horas;

(3) solução aquosa pH 7 a $45^{\circ} \mathrm{C}$, por 24 horas;

(4) solução aquosa pH 7 à temperatura ambiente, por 24 horas;

(5) solução aquosa $\mathrm{pH} 9$ a $55^{\circ} \mathrm{C}$, por 24 horas;

(6) tampão fosfato de sódio $0,05 \mathrm{M} \mathrm{pH} 7$ a $45{ }^{\circ} \mathrm{C}$, na presença ou ausência do inibidor imidazol (Yeoh \& Wee, 1994), na concentração de $10 \mathrm{mM}$, por 1 hora.

As extrações 4 e 5 foram realizadas nas mesmas condições de obtenção de IPS. As extrações foram realizadas na proporção $1: 20(\mathrm{~m} / \mathrm{v})$ e os extratos centrifugados a $11.951 \mathrm{~g} / 20 \mathrm{~min}\left(25^{\circ} \mathrm{C}\right)$. Os sobrenadantes foram analisados em relação ao teor e perfil das isoflavonas, conforme 3.3.2. As extrações foram realizadas em duplicata. 


\subsection{Solubilização de proteínas e isoflavonas a partir de isolado protéico de soja (IPS) comercial}

A solubilização de proteínas e isoflavonas do IPS comercial por diversas soluções foi realizada utilizando-se a proporção IPS:solução $1: 40(\mathrm{~m} / \mathrm{v})$, sendo a suspensão mantida sob agitação com agitador mecânico e barra magnética durante 1 hora a $4^{\circ} \mathrm{C}$. As soluções testadas foram água, solução aquosa com pH variando de 2 a 10, soluções de $\mathrm{NaCl}$ 0,05 M, 0,2 M e 0,5 M, soluções de SDS $0,1 \%$ e $1 \%$, soluções de Triton $X-1000,1 \%, 0,5 \%$ e $1 \%$,e soluções de $\beta$-ME 0,001 M, 0,01 M, 0,02 M e 0,2 M. As soluções de SDS, Triton X-100 e $\beta$-ME foram preparadas em tampão fosfato de sódio 0,05 M pH 7. A suspensão foi então centrifugada (11.951 $\mathrm{g} / 10 \mathrm{~min}$ a $4^{\circ} \mathrm{C}$ ) e o sobrenadante analisado em relação ao teor protéico pelo método de micro-Kjeldahl, perfil eletroforético e teor e perfil das isoflavonas. As análises foram realizadas em triplicata.

\subsection{Análise dos resultados}

Os resultados foram analisados através da comparação das médias e desvios-padrões utilizando-se o programa Statistica versão 5.0 da StatSoft (Tulsa, E.U.A.). A comparação das médias foi realizada por análise de variância (ANOVA) e pelo teste LSD $(P<0,05)$. 


\section{RESULTADOS E DISCUSSÃO}

\subsection{Caracterização da farinha desengordurada de soja (FDS).}

A farinha desengordurada de soja foi caracterizada em relação aos teores de umidade, proteínas e isoflavonas, que são apresentados na Tabela 2. Os teores de umidade e proteínas corresponderam aos valores normalmente encontrados para esse produto. O teor de isoflavonas está dentro da faixa (156,5 a 203,2 mg/100 g) relatado por Genovese e Lajolo (2001a).

Tabela 2. Teores de umidade, proteínas e isoflavonas da farinha desengordurada de soja.

\begin{tabular}{c|c}
\hline & Média $\pm \mathrm{DP}$ \\
\hline Umidade $(\mathrm{g} / 100 \mathrm{~g})$ & $5,4 \pm 0,2$ \\
Proteínas $(\mathrm{g} / 100 \mathrm{~g})$ & $51,5 \pm 0,2$ \\
Isoflavonas totais* $(\mathrm{mg} / 100 \mathrm{~g})$ & $193 \pm 3$ \\
\hline * O teor de isoflavonas totais foi expresso como agliconas.
\end{tabular}

A Tabela 3 mostra o perfil da distribuição das isoflavonas observado na FDS (\% de malonilglicosídeos, \% de acetilglicosídeos, $\%$ de $\beta$-glicosídeos e \% de agliconas), e a porcentagem total das três isoflavonas presentes (daidzeína, genisteína e gliciteína). 
Tabela 3. Perfil de isoflavonas extraídas a partir da farinha desengordurada de soja, em $\mathrm{MeOH} 80 \%$.

\begin{tabular}{c|c}
\hline & \multicolumn{1}{|c}{$\%$} \\
\hline$\beta$-glicosídeos & $43,4 \pm 0,4$ \\
Malonilglicosídeos & $46,8 \pm 0,6$ \\
Acetilglicosídeos & $4,1 \pm 0,3$ \\
Agliconas & $5,7 \pm 0,4$ \\
Daidzeína total & $37,3 \pm 0,2$ \\
Gliciteína total & $7,8 \pm 0,1$ \\
Genisteína total & $54,9 \pm 0,2$ \\
\hline
\end{tabular}

Resultados na forma de média \pm desvio-padrão $(n=3)$.

Os malonilglicosídeos e os $\beta$-glicosídeos foram os conjugados encontrados em maior proporção. Os resultados estão de acordo com Barnes et al. (1994), que encontraram na soja e na FDS uma quantidade maior de malonilglicosídeos e $\beta$-glicosídeos e quantidades bem menores de agliconas e acetilglicosídeos.

Kudou et al. (1991) observaram uma grande quantidade de malonilglicosídeos no grão de soja, e posteriormente Barnes et al. (1994) e Coward et al. (1998) relataram que a porcentagem das isoflavonas conjugadas da soja não muda em relação à FDS.

A Figura 4 mostra o cromatograma obtido através de CLAE referente à separação das isoflavonas da FDS. 


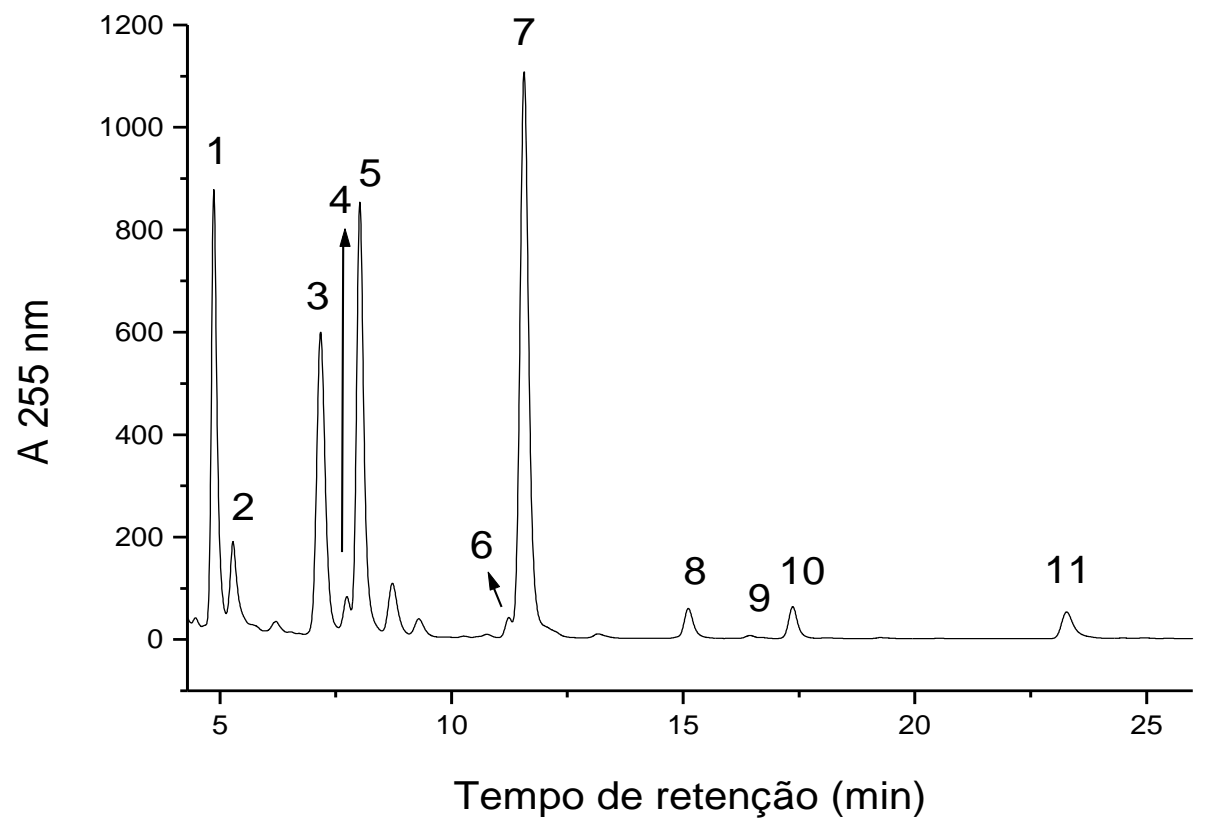

Figura 4. Cromatograma obtido por CLAE da farinha desengordurada de soja. Solvente A: ácido acético 0,1\% em água; solvente $B$ : ácido acético 0,1\% em acetonitrila. A fase móvel consistiu em gradiente linear de acetonitrila em fluxo de $1 \mathrm{~mL} / \mathrm{min}$. 1 . daidzina, 2 . glicitina, 3 . malonildaidzina, 4. malonilglicitina, 5. genistina, 6 . acetildaidzina, 7. malonilgenistina, 8. daidzeína, 9. gliciteína, 10. acetilgenistina, 11. genisteína.

Através do cromatograma foram detectados os seguintes compostos na FDS: daidzina, glicitina, malonildaidzina, malonilglicitina, genistina, acetildaidzina, malonilgenistina, daidzeína, gliciteína, acetilgenistina e genisteína. No trabalho de Genovese \& Lajolo (2001a) não foram detectadas as formas malonilglicitina e gliciteína na farinha desengordurada, e Simonne et al. (2000) não detectaram as formas gliciteína, acetildaizina e daidzeína na variedade de soja Hutcheson. A diferença nos 
resultados se deve, provavelmente, às baixas concentrações dessas formas.

Em seguida à caracterização da FDS foram analisadas as melhores condições de extração de isoflavonas e de proteínas visando à obtenção do isolado protéico de soja (IPS) com teor aumentado de isoflavonas.

4.2. Efeito da razão farinha:água sobre a eficiência de extração das proteínas a partir da farinha desengordurada de soja.

Inicialmente, foi determinada a melhor razão farinha:água $(\mathrm{m} / \mathrm{v})$ para a extração das proteínas a partir da FDS (Figura 5).

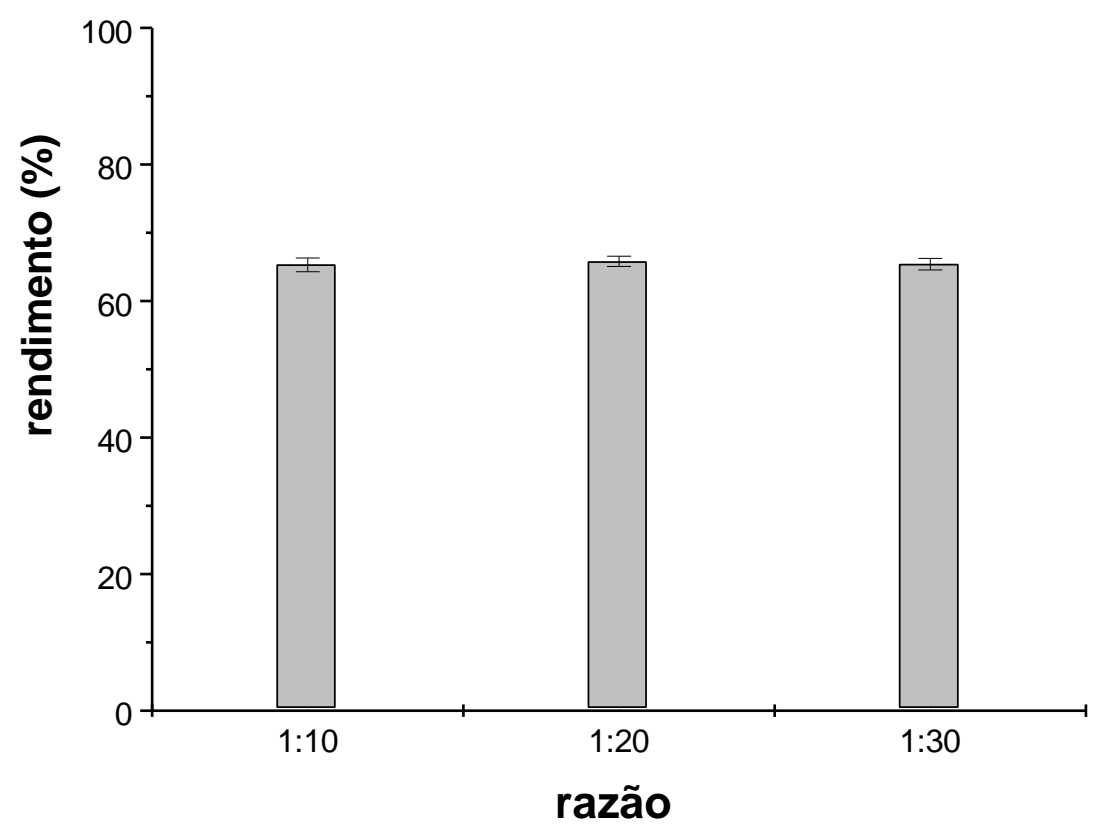

Figura 5. Rendimento da extração das proteínas da farinha desengordurada de soja em água na razão 1:10, 1:20 e $1: 30(\mathrm{~m} / \mathrm{v})$. 
Não houve diferença significativa nas três razões analisadas $(1: 10,1: 20,1: 30)$, com uma média de $65 \%$ das proteínas da FDS solubilizadas em água. A partir destes resultados, selecionou-se a razão 1:20 para as extrações posteriores.

\subsection{Efeito do tempo e da temperatura sobre a eficiência de extração das isoflavonas e das proteínas em água.}

Foram testados os tempos de extração de 1 e 3 horas e observou-se que, independente da temperatura utilizada $(4,25$ ou $50{ }^{\circ} \mathrm{C}$ ), o aumento do tempo não resultou em maior rendimento protéico (Figura 6). Já o aumento da temperatura proporcionou um aumento na eficiência de extração das proteínas, de $64 \%$ a $4{ }^{\circ} \mathrm{C}$ para $88 \%$ a $50{ }^{\circ} \mathrm{C}$.

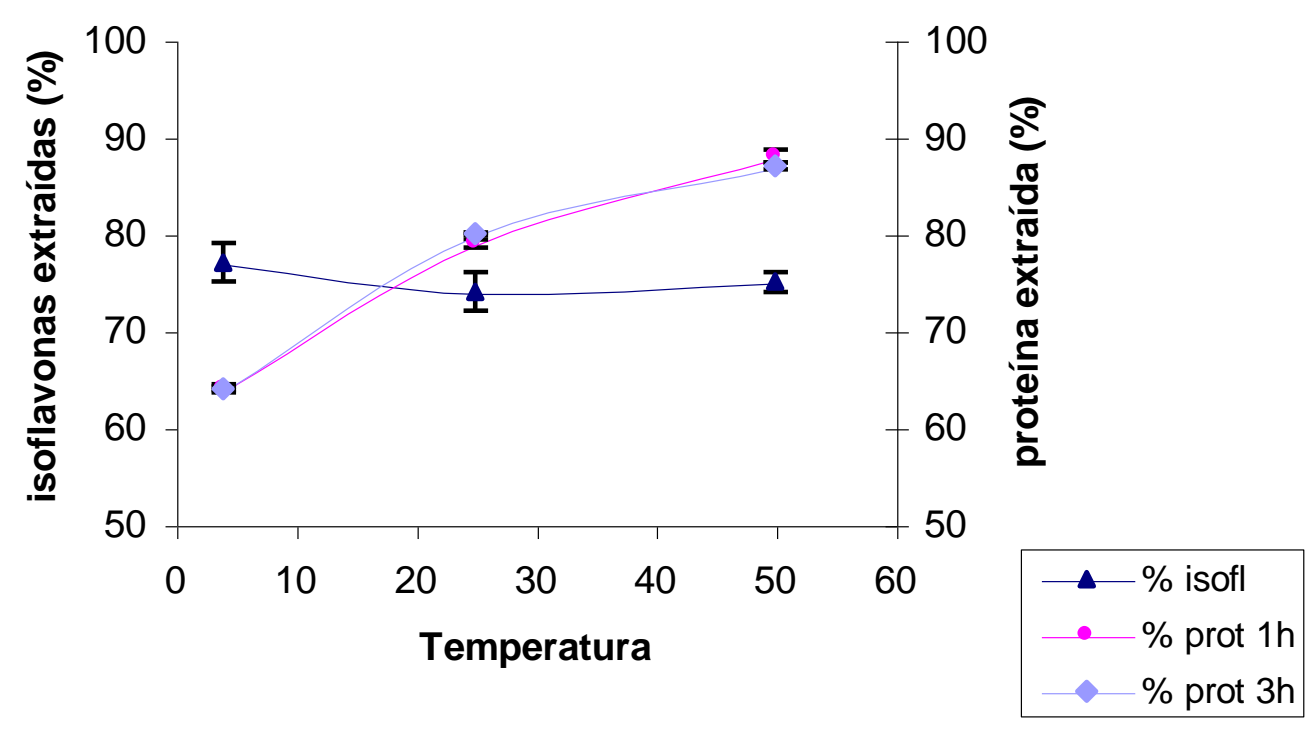

Figura 6. Efeito do tempo e da temperatura na extração de proteínas e isoflavonas a partir da farinha desengordurada de soja. 
A seguir, usando-se o tempo de 1 hora de extração, determinou-se o efeito da temperatura sobre a extração das isoflavonas em meio aquoso. Ao contrário do observado para as proteínas, não houve diferença significativa entre as três temperaturas, tendo como média um rendimento de cerca de $76 \%$ do total de isoflavonas contidas na FDS extraídas em meio aquoso.

Visto que a temperatura de extração não interfere no rendimento de isoflavonas, definiram-se como parâmetros de extração o tempo de 1 hora e a temperatura de $4{ }^{\circ} \mathrm{C}$, já que a temperatura ambiente pode variar significativamente e a temperatura de $50{ }^{\circ} \mathrm{C}$ leva à alteração no perfil de isoflavonas, como posteriormente verificado.

\subsection{Efeito da força iônica sobre a eficiência de extração das isoflavonas e das proteínas.}

Utilizaram-se soluções de $\mathrm{NaCl}$ nas concentrações de 0,01 M, $0,1 \mathrm{M}, 0,2 \mathrm{M}, 0,5 \mathrm{M}$ e $1,0 \mathrm{M}$, e a extração foi realizada a $4{ }^{\circ} \mathrm{C}$, em pH 7 por 1 hora. Na Figura 7 observa-se que forças iônicas entre 0,1 M e 0,2 M causam uma diminuição na extração tanto de proteínas como de isoflavonas, e quando se aumenta ou diminui a força iônica além dessa faixa, aumenta-se a porcentagem de extração de proteínas e de isoflavonas, atingindo-se um valor máximo em cerca de 0,5 $\mathrm{M}$.

A maioria das proteínas segue o comportamento do chamado efeito "salting-in", onde para uma determinada temperatura e $\mathrm{pH}$ tem-se o aumento da solubilidade protéica com o aumento da concentração de sal, resultante do efeito do sal sobre as interações eletrostáticas, neutralizando os grupos com cargas na superfície das proteínas (Fennema, 1996). 
Foi detectado por Iwabuchi \& Yamauchi (1984) e Hermansson (1978) que concentrações salinas baixas (ao redor de 0,01 $\mathrm{M}$ de $\mathrm{NaCl}$ ) causam aumento das interações hidrofóbicas, diminuindo a solubilidade protéica. O aumento da força iônica até 2,0 provoca aumento da solubilidade.

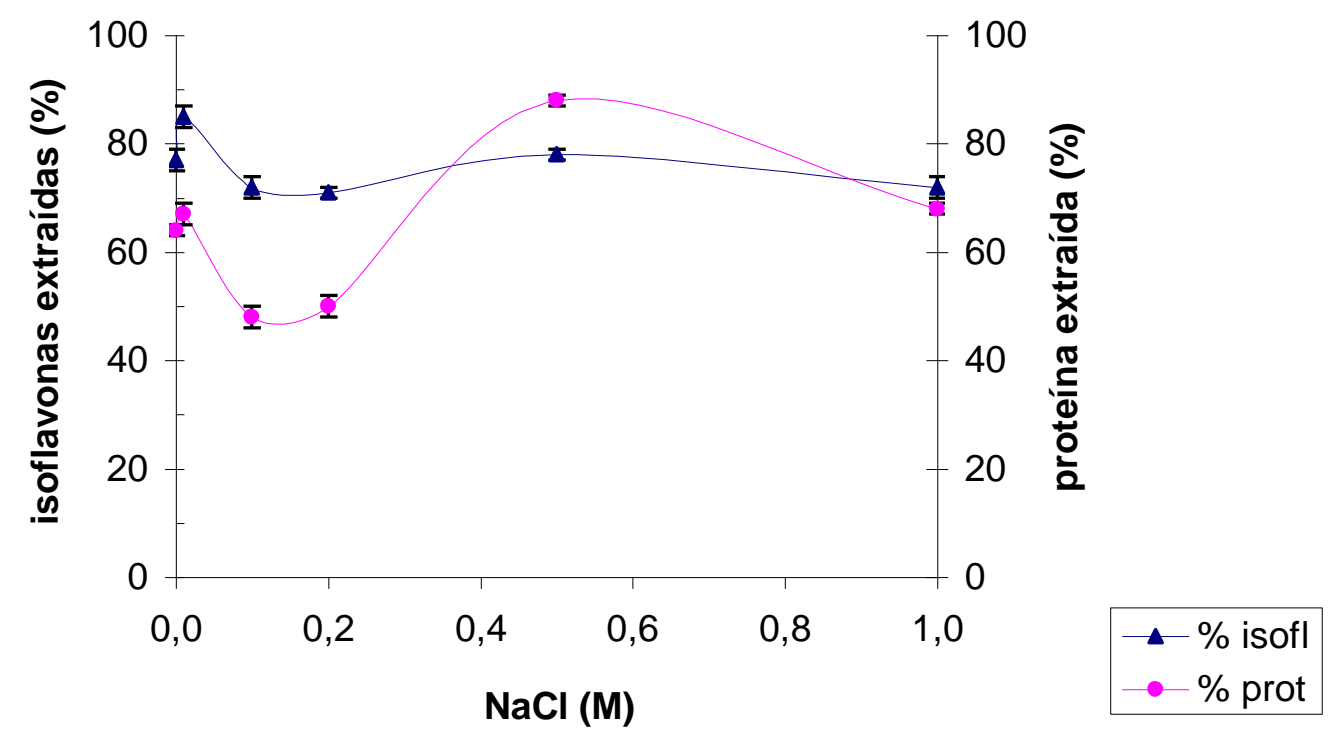

Figura 7. Efeito da força iônica sobre a extração de proteínas e isoflavonas a partir da farinha desengordurada de soja.

\subsection{Efeito do pH sobre a eficiência de extração das isoflavonas e das proteínas.}

A faixa de $\mathrm{pH}$ testada foi de 2 a 10, já que valores acima ou abaixo destes podem causar reações hidrolíticas. A Figura 8 mostra que na região próxima ao $\mathrm{pH}$ isoelétrico das proteínas ( $\mathrm{pI} \sim 4,5$ ) houve uma diminuição drástica da eficiência de extração das proteínas e a curva de isoflavonas acompanhou essa queda. A explicação para esse fato é que ao redor do $\mathrm{pH}$ isoelétrico a solubilidade é mínima, devido à falta de repulsão eletrostática, 
promovendo assim a agregação e insolubilização via interações hidrofóbicas.

Valores acima ou abaixo do pI resultaram em maior eficiência de extração tanto de proteínas como de isoflavonas. No entanto, embora valores de $\mathrm{pH}$ acima de 7 tenham causado um aumento significativo do rendimento de proteínas, este não foi acompanhado de forma proporcional pelas isoflavonas, cujo rendimento foi de $81 \%$ em pH 7 e $89 \%$ em pH 10.

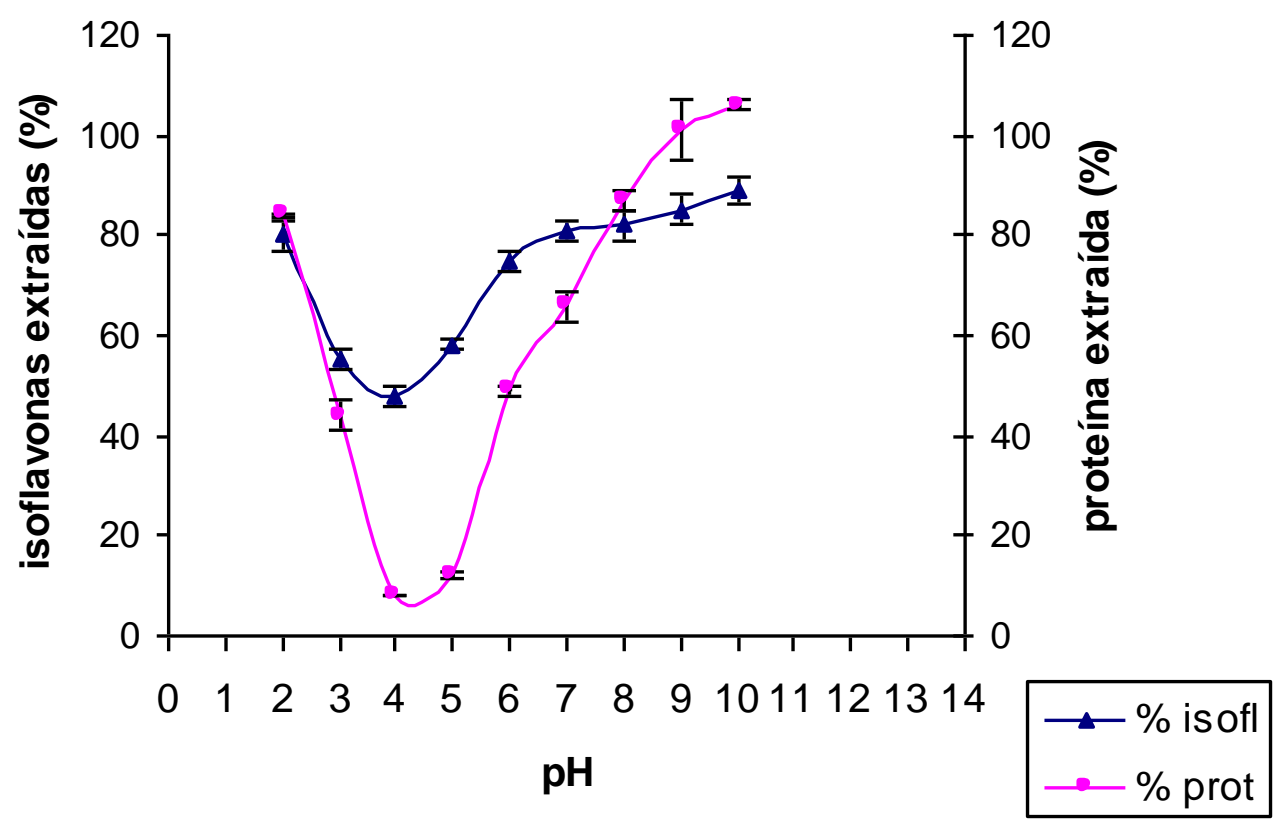

Figura 8. Efeito do pH sobre a extração de proteínas e isoflavonas a partir da farinha desengordurada de soja, sendo que os extratos básicos tiveram seus $\mathrm{pH}$ ajustados para 7 antes de passar pela coluna de poliamida.

Diante desses dados, pode-se concluir que as melhores condições para uma maior extração tanto de proteínas como de 
isoflavonas foram 0 tempo de 1 hora, razão farinha:água $(1: 20 \mathrm{~m} / \mathrm{v})$, temperatura de $4{ }^{\circ} \mathrm{C}$ e pH de extração acima de 7 .

\subsection{Efeito das condições de extração sobre o perfil de isoflavonas.}

As Tabelas 4 a 6 mostram a variação de distribuição das isoflavonas (\% de malonilglicosídeos, \% de acetilglicosídeos, \% de $\beta$-glicosídeos e \% de agliconas e a \% das três agliconas presentes, daidzeína, genisteína e gliciteína) extraídas a partir da FDS em diferentes condições.

$\mathrm{Na}$ extração realizada à temperatura ambiente houve um pequeno aumento de agliconas, com diminuição proporcional de $\beta$-glicosídeos, em relação à extração realizada a $4^{\circ} \mathrm{C}$. Já a $50{ }^{\circ} \mathrm{C}$, as isoflavonas na forma de agliconas corresponderam a $20 \%$ do total extraído, com uma grande queda dos $\beta$-glicosídeos (Tabela 4). Pode-se observar ainda, que o aumento da temperatura não alterou a porcentagem de acetilglicosídeos nem a de malonilglicosídeos.

Wang et al. (1998) encontraram para a FDS $99 \%$ das isoflavonas como glicosídeos. No presente trabalho, o valor encontrado foi $97 \%$ para os glicosídeos na temperatura de $4{ }^{\circ} \mathrm{C}$. Entretanto, os teores dos glicosídeos extraídos a $50{ }^{\circ} \mathrm{C}$ diminuem para $80 \%$, indicando portanto, que os glicosídeos presentes nos extratos a $4{ }^{\circ} \mathrm{C}$ e na temperatura ambiente foram hidrolisados nos extratos a $50{ }^{\circ} \mathrm{C}$ (Tabela 4).

Coward et al. (1998) e Kudou et al. (1991) reportaram que o perfil das isoflavonas depende da temperatura empregada durante o processamento dos produtos de soja. O calor causa a desesterificação dos conjugados malonilglicosídeos e acetilglicosídeos para os respectivos $\beta$-glicosídeos, porém isto foi 
relatado para temperaturas acima da temperatura utilizada neste trabalho $\left(50{ }^{\circ} \mathrm{C}\right)$. Coward et al. (1998) e Barnes et al. (1994) reportaram que durante a extração metanólica a $80{ }^{\circ} \mathrm{C}$ ocorria a conversão completa de malonilglicosídeos e acetilglicosídeos para $\beta$-glicosídeos.

O calor seco causa uma perda do dióxido de carbono (descarboxilação) dos malonilglicosídeos, levando à formação de quantidade substancial de acetilglicosídeos, como ocorre na tostagem de farinha ou na extrusão utilizada no processo de texturização (Coward et al., 1993; Mahungu et al., 1999). O calor úmido provoca a desesterificação dos malonilglicosídeos e acetilglicosídeos para os $\beta$-glicosídeos, utilizado no processamento de tofu e leite de soja (Grün et al., 2001; Coward et al., 1993). O calor úmido em temperaturas abaixo de $50{ }^{\circ} \mathrm{C}$, também pode causar hidrólise dos $\beta$-glicosídeos com aumento das agliconas, pela ação das $\beta$-glicosidases endógenas, observado após o molho da soja, na primeira etapa de produção do leite de soja (Matsuura \& Obata, 1993; Matsuura et al., 1989).

Os resultados aqui obtidos indicam a ação das $\beta$-glicosidases endógenas, já que a FDS foi extraída em água e a temperatura empregada está na faixa de atividade da enzima (10 a $50{ }^{\circ} \mathrm{C}$ ), conforme posteriormente verificado (item 4.10). No entanto, Mahungu et al. (1999) obtiveram um resultado inverso em condições onde a água do meio era limitante (processo de extrusão) e a temperatura empregada foi a de inativação da $\beta$-glicosidase, o que favoreceu, neste caso, a descarboxilação sobre a hidrólise. 
Tabela 4. Perfil de isoflavonas extraídas a partir da farinha desengordurada de soja em diferentes temperaturas.

\begin{tabular}{|c|c|c|c|}
\hline & \multicolumn{3}{|c|}{ \% de extração } \\
\hline & $4^{\circ} \mathrm{C}$ & temp. amb. & $50^{\circ} \mathrm{C}$ \\
\hline$\beta$-glicosídeos & $38,5 \pm 0,9^{\mathrm{a}}$ & $34,5 \pm 0,5^{b}$ & $19,2 \pm 0,4^{\mathrm{c}}$ \\
\hline M glicosídeos & $57 \pm 1^{\mathrm{d}}$ & $57,3 \pm 0,7^{\mathrm{d}}$ & $59,0 \pm 0,4^{\mathrm{d}}$ \\
\hline Ac glicosídeos & $1,5 \pm 0,1^{\mathrm{e}}$ & $1,6 \pm 0,1^{\mathrm{e}}$ & $1,9 \pm 0,3^{\mathrm{e}}$ \\
\hline Agliconas & $3,3 \pm 0,1^{\mathrm{f}}$ & $6,5 \pm 0,2^{\mathrm{g}}$ & $19,9 \pm 0,6^{\mathrm{h}}$ \\
\hline Daidzeína total & $39 \pm 2^{a}$ & $38 \pm 1^{\mathrm{a}}$ & $34,4 \pm 0,5^{b}$ \\
\hline Gliciteína total & $9 \pm 2^{c}$ & $9 \pm 1^{c}$ & $8,9 \pm 0,7^{\mathrm{c}}$ \\
\hline Genisteína total & $52 \pm 3^{\mathrm{d}}$ & $53 \pm 2^{\mathrm{d}}$ & $57 \pm 1^{\mathrm{e}}$ \\
\hline $\begin{array}{l}\text { Resultados na forn } \\
\text { com letras difere } \\
\text { utilizadas as abr } \\
\text { respectivamente. }\end{array}$ & $\begin{array}{l}\text { édia } \pm \text { des } \\
\text { M signific } \\
M \quad A\end{array}$ & $\begin{array}{l}\text { o }(n=3) \text {. } \\
\text { te diferer } \\
\text { os radic }\end{array}$ & $\begin{array}{l}\text { a mesma I } \\
(0,05) \text {. Fo } \\
\text { onil e ac }\end{array}$ \\
\hline
\end{tabular}

A Tabela 5 mostra que a força iônica não influenciou o perfil das isoflavonas extraídas em meio aquoso nas concentrações de $\mathrm{NaCl} 0,01 \mathrm{M}, 0,1 \mathrm{M}, 0,2 \mathrm{M}, 0,5 \mathrm{M}$ e 1,0 M. 
Tabela 5. Perfil de isoflavonas extraídas a partir da farinha desengordurada de soja em diferentes forças iônicas.

\begin{tabular}{|c|c|c|c|c|c|}
\hline & \multicolumn{5}{|c|}{ \% de extração } \\
\hline & NaCl 0,01 M & $\mathrm{NaCl} 0,1 \mathrm{M}$ & $\mathrm{NaCl} 0,2 \mathrm{M}$ & $\mathrm{NaCl} 0,5 \mathrm{M}$ & $\mathrm{NaCl} 1,0 \mathrm{M}$ \\
\hline$\beta$-glicosídeos & $45 \pm 2^{a}$ & $40 \pm 3^{\mathrm{a}}$ & $46 \pm 1^{\mathrm{a}}$ & $44 \pm 3^{\mathrm{a}}$ & $45 \pm 1^{\mathrm{a}}$ \\
\hline M glicosídeos & $49 \pm 2^{b}$ & $54 \pm 1^{c}$ & $50 \pm 1^{b}$ & $50 \pm 2^{b}$ & $49 \pm 1^{b}$ \\
\hline Ac glicosídeos & $0,6 \pm 0,2^{\mathrm{c}}$ & $0,4 \pm 0,2^{\mathrm{c}}$ & $0,5 \pm 0,1^{\mathrm{c}}$ & $0,6 \pm 0,2^{\mathrm{c}}$ & $0,7 \pm 0,1^{\mathrm{c}}$ \\
\hline Agliconas & $4,5 \pm 0,7^{\mathrm{d}}$ & $5,2 \pm 0,4^{\mathrm{d}}$ & $3,7 \pm 0,3^{\mathrm{d}}$ & $5 \pm 1^{d}$ & $5,4 \pm 0,4^{\mathrm{d}}$ \\
\hline Daidzeína total & $44 \pm 3^{\mathrm{a}}$ & $47 \pm 2^{\mathrm{a}}$ & $48 \pm 1^{\mathrm{a}}$ & $46 \pm 2^{\mathrm{a}}$ & $46 \pm 4^{\mathrm{a}}$ \\
\hline Gliciteína total & $8 \pm 1^{b}$ & $8 \pm 1^{b}$ & $8,0 \pm 0,4^{b}$ & $7,7 \pm 0,5^{\mathrm{b}}$ & $8 \pm 1^{b}$ \\
\hline Genisteína total & $47 \pm 2^{c}$ & $44 \pm 2^{c}$ & $44 \pm 1^{c}$ & $46 \pm 2^{c}$ & $46 \pm 4^{c}$ \\
\hline
\end{tabular}

$\mathrm{Na}$ Tabela 6, pode-se notar que nos $\mathrm{pH}$ básicos ( $\mathrm{pH} 8$ a 10), e abaixo de $\mathrm{pH} 4$ têm-se 0 favorecimento da reação de desesterificação. As formas acetilglicosídeos e agliconas tiveram uma variação mínima. A isoflavona que aparece em maior proporção é a genisteína e a porcentagem de gliciteína foi maior entre os $\mathrm{pH} 3$ a 5. 
Tabela 6. Perfil de isoflavonas extraídas a partir da farinha desengordurada de soja em diferentes pH.

\begin{tabular}{|c|c|c|c|c|c|c|c|c|c|}
\hline & \multicolumn{9}{|c|}{ \% de extração } \\
\hline & pH 2 & pH 3 & pH 4 & pH 5 & pH 6 & pH 7 & pH 8 & pH 9 & pH 10 \\
\hline$\beta$-glicosídeos & $44 \pm 1^{\mathrm{a}}$ & $48 \pm 1^{\mathrm{b}}$ & $49 \pm 2^{b, d}$ & $44 \pm 1^{\mathrm{a}}$ & $46 \pm 1^{\mathrm{a}, \mathrm{b}}$ & $45 \pm 2^{\mathrm{a}, \mathrm{b}}$ & $50 \pm 1^{\mathrm{d}}$ & $51 \pm 1^{\mathrm{d}}$ & $53 \pm 1^{d}$ \\
\hline M glicosídeos & $46 \pm 2^{\mathrm{e}}$ & $44 \pm 1^{\mathrm{e}}$ & $43 \pm 1^{\mathrm{e}}$ & $50,2 \pm 0,3^{\mathrm{f}}$ & $49 \pm 1^{\mathrm{f}}$ & $50 \pm 1^{\mathrm{f}}$ & $43 \pm 2^{\mathrm{e}, \mathrm{g}}$ & $42 \pm 2^{e, g}$ & $39 \pm 1^{g}$ \\
\hline Ac glicosídeos & $1,3 \pm 0,1^{\mathrm{h}}$ & $1,3 \pm 0,1^{\mathrm{h}}$ & $1,1 \pm 0,2^{\mathrm{h}}$ & $0,9 \pm 0,1^{\mathrm{h}}$ & $0,5 \pm 0,1^{\mathrm{i}}$ & $0,3 \pm 0,1^{\mathrm{i}}$ & $0,5 \pm 0,1^{\mathrm{i}}$ & $0,5 \pm 0,2^{\mathrm{i}}$ & $0,5 \pm 0,2^{\mathrm{i}}$ \\
\hline Agliconas & $6,3 \pm 0,4^{\mathrm{j}}$ & $6,6 \pm 0,3^{j}$ & $6,3 \pm 0,4^{\mathrm{j}}$ & $4,8 \pm 0,3^{1}$ & $5,4 \pm 0,5^{1}$ & $5 \pm 1^{\mathrm{j}, 1}$ & $7 \pm 1^{\mathrm{j}, \mathrm{m}}$ & $8 \pm 1^{\mathrm{j}, \mathrm{m}}$ & $7 \pm 1^{\mathrm{j}, \mathrm{m}}$ \\
\hline Daidzeína total & $39 \pm 2^{\mathrm{a}}$ & $38 \pm 1^{\mathrm{a}}$ & $42 \pm 2^{\mathrm{a}}$ & $40 \pm 2^{\mathrm{a}}$ & $40 \pm 2^{\mathrm{a}}$ & $38 \pm 3^{\mathrm{a}}$ & $38 \pm 2^{\mathrm{a}}$ & $37 \pm 4^{\mathrm{a}}$ & $36 \pm 3^{a}$ \\
\hline Gliciteína total & $8 \pm 1^{b}$ & $12 \pm 1^{\mathrm{c}}$ & $12 \pm 1^{\mathrm{c}}$ & $12 \pm 1^{\mathrm{c}}$ & $9 \pm 1^{b}$ & $7 \pm 2^{b}$ & $6 \pm 1^{b}$ & $6 \pm 1^{b}$ & $7 \pm 1^{b}$ \\
\hline Genisteína total & $53 \pm 3^{\mathrm{d}}$ & $47 \pm 2^{\mathrm{e}}$ & $46 \pm 2^{\mathrm{e}}$ & $48 \pm 1^{\mathrm{e}}$ & $52 \pm 2^{d}$ & $55 \pm 2^{d}$ & $57 \pm 3^{\mathrm{d}}$ & $57 \pm 2^{d}$ & $57 \pm 3^{d}$ \\
\hline
\end{tabular}

Resultados na forma de média \pm desvio-padrão $(n=3)$. n.d. não detectados. Médias na mesma linha com letras diferentes são significativamente diferentes $(p<0,05)$. Foram utilizadas as abreviações $M$ e Ac para os radicais malonil e acetil, respectivamente. 


\subsection{Etapa de precipitação das proteínas da soja.}

A segunda etapa no preparo dos isolados protéicos consiste da precipitação isoelétrica das proteínas extraídas em meio aquoso a partir da FDS. Os IPS comerciais são normalmente preparados através da extração da FDS em meio alcalino, utilizando pH entre 8 e 10, e da precipitação protéica em pH 4,5.

Com a finalidade de se obter a melhor relação entre isoflavonas e proteínas no IPS preparado a partir da FDS, foram testados os pH de precipitação 4, 4,5 e 5 .

A Tabela 7 mostra 0 rendimento da precipitação das isoflavonas e proteínas nos $\mathrm{pH} 4,4,5$ e 5 . A FDS contém $192,5 \mathrm{mg}$ de isoflavonas $/ 100 \mathrm{~g} \mathrm{e} 51,5 \%$ de proteína. O extrato aquoso obtido em pH $7(1: 20 \mathrm{~m} / \mathrm{v})$ apresentou um rendimento de $157,7 \mathrm{mg}$ de isoflavonas e $34,9 \mathrm{~g}$ de proteína por $100 \mathrm{~g}$ de FDS. 0 precipitado obtido em $\mathrm{pH} 4$ apresentou uma porcentagem maior de isoflavonas em relação ao $\mathrm{pH} 5$, porém não foi significativamente diferente do rendimento obtido em pH 4,5. No entanto, em pH 4,5 o rendimento protéico foi significativamente maior.

Tabela 7. Recuperação de isoflavonas e proteínas nos precipitados isoelétricos em $\mathrm{pH}$ 4, 4,5 e 5 a partir do extrato aquoso $(\mathrm{pH} 7)$ da farinha desengordurada de soja.

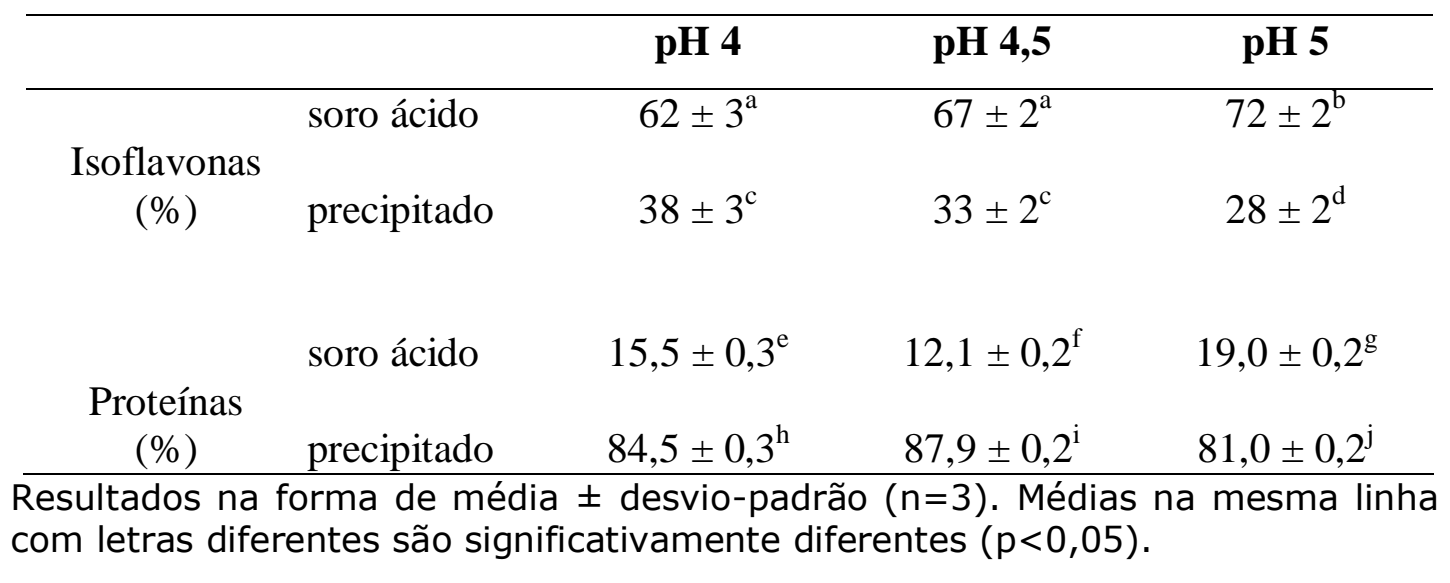


A Tabela 8 apresenta a razão isoflavonas/ proteínas e mostra que o precipitado obtido em $\mathrm{pH} 4$ foi o mais rico em isoflavonas, como resultado de uma quantidade menor de proteínas precipitadas em relação ao $\mathrm{pH} 4,5$. Para efeito de comparação, a FDS apresenta uma razão de 374,8 mg de isoflavonas por $100 \mathrm{~g}$ de proteína, e o extrato aquoso $(\mathrm{pH} 7)$ de $451,9 \mathrm{mg}$ de isoflavonas por $100 \mathrm{~g}$ de proteína.

Estes resultados mostram que há uma perda significativa de isoflavonas na etapa de precipitação.

Tabela 8. Razão das isoflavonas e proteínas precipitadas no $\mathrm{pH}$, 4,5 e 5 a partir da solução aquosa da farinha desengordurada de soja.

\begin{tabular}{cccc}
\hline & pH 4 & pH 4,5 & pH 5 \\
\hline $\begin{array}{c}\text { soro ácido } \\
(\mathrm{mg} \text { isofl/100 g prot) }\end{array}$ & $1821^{\mathrm{a}}$ & $2518^{\mathrm{b}}$ & $1715^{\mathrm{c}}$ \\
$\begin{array}{c}\text { precipitado } \\
(\mathrm{mg} \text { isofl/100 g prot) }\end{array}$ & $200^{\mathrm{d}}$ & $170^{\mathrm{e}}$ & $130^{\mathrm{f}}$ \\
\hline Médias com letras diferentes são significativamente diferentes $(\mathrm{p}<0,05)$.
\end{tabular}

Assim, através desses dados, conclui-se que o $\mathrm{pH} 4,5$ foi o melhor $\mathrm{pH}$ para a precipitação das proteínas associadas às isoflavonas. 


\subsection{Obtenção do isolado protéico de soja com teor aumentado de isoflavonas.}

A partir dos resultados obtidos, sete diferentes IPS foram preparados sendo que, para cada um, algum parâmetro da etapa de processamento foi alterado, conforme segue:

Isolado I) $50 \mathrm{~g}$ farinha/1000 $\mathrm{mL} \mathrm{H}_{2} \mathrm{O}$ destilada/ $\mathrm{pH} 7$ a $26{ }^{\circ} \mathrm{C}-$ primeira centrifugação a $16.274 \mathrm{~g} / 20 \mathrm{~min}$ a $25{ }^{\circ} \mathrm{C}$ - precipitação $\mathrm{pH} 4,5$ - centrifugação do soro ácido e da água de lavagem a $16.274 \mathrm{~g} / 20 \mathrm{~min}$ a $25^{\circ} \mathrm{C}$.

Isolado II) $10 \mathrm{~g}$ farinha/200 mL $\mathrm{H}_{2} \mathrm{O}$ destilada/ $\mathrm{pH} 7$ a $24{ }^{\circ} \mathrm{C}-$ precipitação $\mathrm{pH} 4$ - centrifugação do soro ácido e da água de lavagem a $16.274 \mathrm{~g} / 20 \mathrm{~min}$ a $25^{\circ} \mathrm{C}$.

Isolado III) $10 \mathrm{~g}$ farinha/200 mL H $2 \mathrm{O}$ destilada/ $\mathrm{pH} 7$ a $22{ }^{\circ} \mathrm{C}-$ precipitação $\mathrm{pH} 4,5$ - centrifugação do soro ácido e da água de lavagem a $16.274 \mathrm{~g} / 20 \mathrm{~min}$ a $25{ }^{\circ} \mathrm{C}$.

Isolado IV) $10 \mathrm{~g}$ farinha/200 mL $\mathrm{H}_{2} \mathrm{O}$ destilada/ $\mathrm{pH} 7$ a $26{ }^{\circ} \mathrm{C}-$ precipitação $\mathrm{pH} 4,5$ - centrifugação do soro ácido e da água de lavagem a $162 \mathrm{~g} / 2 \mathrm{~min}$ a $25^{\circ} \mathrm{C}$.

Isolado V) $10 \mathrm{~g}$ farinha/200 mL $\mathrm{H}_{2} \mathrm{O}$ destilada/ $\mathrm{pH} 7$ a $24{ }^{\circ} \mathrm{C}-$ precipitação $\mathrm{pH} 4,5$ - centrifugação do soro ácido e da água de lavagem a $162 \mathrm{~g} / 1 \mathrm{~min}$ a $25^{\circ} \mathrm{C}$.

Isolado VI) $10 \mathrm{~g}$ farinha/200 mL $\mathrm{H}_{2} \mathrm{O}$ destilada/ $\mathrm{pH} 9$ a $24{ }^{\circ} \mathrm{C}-$ precipitação $\mathrm{pH} 4,5$ - centrifugação do soro ácido e da água de lavagem a $162 \mathrm{~g} / 2 \mathrm{~min}$ a $25^{\circ} \mathrm{C}$.

Isolado VII) $10 \mathrm{~g}$ farinha/200 mL $\mathrm{H}_{2} \mathrm{O}$ destilada/ $\mathrm{pH} 9$ a $55{ }^{\circ} \mathrm{C}-$ precipitação pH 4,5 - centrifugação do soro ácido e da água de lavagem a $162 \mathrm{~g} / 2 \mathrm{~min}$ a $25^{\circ} \mathrm{C}$.

Os IPS liofilizados foram caracterizados em relação aos teores de umidade, proteínas, e isoflavonas (Tabela 9). Observou- 
se que os produtos obtidos correspondem à definição de IPS, por apresentarem mais de $90 \%$ de proteína $(\mathrm{N} \times 6,25)$.

Os isolados I, II e III foram obtidos em condições mais rigorosas de centrifugação. Como os isolados obtidos industrialmente, antes de serem submetidos à secagem, apresentam consistência mais pastosa ( $\sim 18 \%$ de sólidos) do que estes ( $\sim 50 \%$ de sólidos), para os isolados IV, V, VI e VII foram utilizadas condições bem mais brandas de centrifugação. $O$ objetivo foi verificar se a presença maior de soro ácido nos precipitados resultaria em conteúdo maior de isoflavonas. Assim, a Tabela 9 mostra que a utilização de centrifugação mais branda resultou em aumento de 52 a $80 \%$ no conteúdo de isoflavonas nos isolados IV, V, VI e VII.

Tabela 9. Teores de umidade, proteínas e isoflavonas dos isolados protéicos de soja liofilizados.

\begin{tabular}{|c|c|c|c|c|c|c|c|}
\hline & $\begin{array}{c}\text { Isolado } \\
\text { I }\end{array}$ & $\begin{array}{c}\text { Isolado } \\
\text { II }\end{array}$ & $\begin{array}{c}\text { Isolado } \\
\text { III }\end{array}$ & $\begin{array}{c}\text { Isolado } \\
\text { IV }\end{array}$ & $\begin{array}{c}\text { Isolado } \\
\text { V }\end{array}$ & $\begin{array}{c}\text { Isolado } \\
\text { VI }\end{array}$ & $\begin{array}{c}\text { Isolado } \\
\text { VII }\end{array}$ \\
\hline $\begin{array}{l}\text { Umidade } \\
(\mathrm{g} / 100 \mathrm{~g})\end{array}$ & $1,8 \pm 0,2^{\mathrm{a}}$ & $2,0 \pm 0,7^{\mathrm{a}}$ & $2,0 \pm 0,2^{\mathrm{a}}$ & $2,5 \pm 0,4^{\mathrm{a}}$ & $1,9 \pm 0,1^{\mathrm{a}}$ & $2,1 \pm 0,2^{\mathrm{a}}$ & $2,0 \pm 0,4^{\mathrm{a}}$ \\
\hline $\begin{array}{l}\text { Proteínas } \\
(\mathrm{g} / 100 \mathrm{~g})\end{array}$ & $93,5 \pm 0,5^{\mathrm{b}}$ & $91,2 \pm 0,4^{\mathrm{c}}$ & $93 \pm 2^{b, c}$ & $92,5 \pm 0,3^{b}$ & $92,1 \pm 1^{\mathrm{b}}$ & $90 \pm 2^{b, c}$ & $90,5 \pm 0,5^{c}$ \\
\hline $\begin{array}{c}\text { Isoflavonas* } \\
(\mathrm{mg} / 100 \mathrm{~g})\end{array}$ & $50 \pm 4^{\mathrm{d}}$ & $50 \pm 1^{\mathrm{d}}$ & $48 \pm 2^{\mathrm{d}}$ & $80 \pm 3^{\mathrm{e}}$ & $78 \pm 2^{\mathrm{e}}$ & $76 \pm 4^{\mathrm{e}}$ & $90 \pm 1^{\mathrm{f}}$ \\
\hline
\end{tabular}

Resultados na forma de média \pm desvio-padrão $(n=3)$. Médias na mesma linha com letras diferentes são significativamente diferentes $(p<0,05) . * 0$ teor de isoflavonas totais foi expresso como agliconas.

O rendimento do processo para a obtenção do IPS a partir da FDS variou de 27 a $35 \%(\mathrm{~m} / \mathrm{m})$. Esse rendimento foi maior que o de $17,8 \%$ obtido por Wang \& Murphy (1996) e compatível com os 
$28,9 \%$ obtidos por Wang et al. (1998). A diferença no rendimento é provavelmente decorrente de diferentes condições de extração utilizadas, como pH, temperatura, condições de precipitação e centrifugação.

$\mathrm{O}$ isolado I mostrou-se pobre em isoflavonas, com apenas $10 \%$ do total extraído em $\mathrm{pH} 7$, ficando a maior parte no soro ácido. O resultado se repetiu nos isolados II e III (9 \%), e verificou-se que $\mathrm{o} \mathrm{pH}$ de precipitação não influenciou o rendimento de isoflavonas (Tabela 10).

Tabela 10. Rendimento das etapas de obtenção dos isolados I, II e III (extração em pH 7 à temp. amb., variando-se o pH de precipitação), a partir de $100 \mathrm{~g}$ de farinha desengordurada de soja.

\begin{tabular}{lcc}
\hline & isoflavonas (\%) & proteínas (\%) \\
\hline Extrato pH 7 & 100 & 100 \\
Soro ácido I (pH 4,5) & $70 \pm 2$ & $13,5 \pm 0,1$ \\
Isolado liofilizado I (pH 4,5) & $10 \pm 1$ & $74,6 \pm 0,2$ \\
$\mathrm{H}_{2} \mathrm{O}$ lavagem I (pH 4,5) & $6,1 \pm 0,2$ & $0,4 \pm 0,1$ \\
& & \\
Soro ácido II (pH 4) & $67 \pm 2$ & $13,9 \pm 0,1$ \\
Isolado liofilizado II & $9,0 \pm 0,2$ & $67,7 \pm 0,2$ \\
H & \\
& $5,7 \pm 0,5$ & $0,3 \pm 0,1$ \\
Soro ácido III (pH 4,5) & $74 \pm 2$ & $12,8 \pm 0,2$ \\
Isolado liofilizado III & $8,7 \pm 0,3$ & $67 \pm 1$ \\
$\mathrm{H}_{2} \mathrm{O}$ lavagem acidificada III & $5,1 \pm 0,3$ & $0,3 \pm 0,2$ \\
\hline Resultados na forma de média \pm desvio-padrão ( $\mathrm{n}=3)$.
\end{tabular}


Nos isolados IV, V e VI obteve-se uma quantidade maior de isoflavonas (média de $17 \%$ do extrato total), ajustando-se o tempo e a velocidade de centrifugação (Tabela 11 e 12). Porém a centrifugação não alterou a quantidade de isoflavonas perdida no soro ácido. $\mathrm{O}$ pH de extração do isolado VI foi modificado para pH 9, resultando em maior porcentagem de extração de proteínas e isoflavonas, mas isso não se refletiu em uma maior quantidade de isoflavonas no isolado.

Tabela 11. Rendimento das etapas de obtenção dos isolados IV e $\checkmark$ (extração em pH 7 à temp. amb., variando-se as condições de centrifugação), a partir de $100 \mathrm{~g}$ de farinha desengordurada de soja.

\begin{tabular}{lcc}
\hline & isoflavonas (\%) & proteínas (\%) \\
\hline Extrato pH 7 & 100 & 100 \\
Soro ácido IV & $72 \pm 1$ & $12,0 \pm 0,3$ \\
Isolado liofilizado IV & $15,6 \pm 0,4$ & $65,4 \pm 0,2$ \\
$\mathrm{H}_{2} \mathrm{O}$ lavagem acidificada IV & $7,9 \pm 0,3$ & $1,3 \pm 0,1$ \\
& & \\
Soro ácido V & $75 \pm 3$ & $10,7 \pm 0,1$ \\
Isolado liofilizado V & $19 \pm 1$ & $66,6 \pm 0,6$ \\
$\mathrm{H}_{2} \mathrm{O}$ lavagem acidificada $\mathrm{V}$ & $9,6 \pm 0,3$ & $1,3 \pm 0,1$ \\
\hline
\end{tabular}

Resultados na forma de média \pm desvio-padrão $(n=3)$. 
Tabela 12. Rendimento das etapas de obtenção do isolado VI (extração em pH 9 à temp. amb.), a partir de $100 \mathrm{~g}$ de farinha desengordurada de soja.

\begin{tabular}{lcc}
\hline & isoflavonas (\%) & proteínas (\%) \\
\hline Extrato pH 9 & 100 & 100 \\
Soro ácido VI & $78 \pm 2$ & $9,9 \pm 0,6$ \\
Isolado liofilizado VI & $17 \pm 1$ & $67 \pm 1$ \\
$\mathrm{H}_{2} \mathrm{O}$ lavagem VI & $4,1 \pm 0,1$ & $2,2 \pm 0,1$ \\
\hline \multicolumn{2}{l}{ Resultados na forma de média \pm desvio-padrão $(\mathrm{n}=3)}$.
\end{tabular}

No isolado VII, onde a extração foi realizada em pH 9 a $55{ }^{\circ} \mathrm{C}$, obteve-se um isolado com uma grande quantidade de isoflavonas, $23 \%$ do extrato total, e em relação aos primeiros isolados teve-se um aumento de $129 \%$ do conteúdo de isoflavonas e uma redução de $30 \%$ da sua perda no soro ácido (Tabela 13). Quanto às proteínas extraídas, houve um aumento significativo em relação à extração realizada em $\mathrm{pH} 9$ à temperatura ambiente, confirmando os dados da Figura 6.

Tabela 13. Rendimento das etapas de obtenção do isolado VII (extração em pH 9 a $55^{\circ} \mathrm{C}$ ), a partir de $100 \mathrm{~g}$ de farinha desengordurada de soja.

\begin{tabular}{lcc}
\hline & isoflavonas (\%) & proteínas (\%) \\
\hline Extrato pH 9 & 100 & 100 \\
Soro ácido VII & $37 \pm 4$ & $8 \pm 1$ \\
Isolado liofilizado VII & $23 \pm 1$ & $65 \pm 3$ \\
$\mathrm{H}_{2} \mathrm{O}$ lavagem VII & $3,2 \pm 0,3$ & $2,0 \pm 0,2$ \\
\hline
\end{tabular}

Resultados na forma de média \pm desvio-padrão $(n=3)$.

Em todos os processos de obtenção de IPS observou-se uma perda de proteínas, em torno de 10 a $13 \%$, no soro ácido, e de 
0,5 a $1 \%$ na água de lavagem do precipitado. Observou-se uma maior porcentagem de proteínas solúveis em pH 9 em relação ao $\mathrm{pH}$ 7, porém não houve uma maior precipitação protéica, representando uma média de $66 \%$ em relação ao extrato aquoso alcalino.

$\mathrm{Na}$ etapa de lavagem do precipitado houve uma perda de 3 a $8 \%$ das isoflavonas, bem mais baixa que os $22 \%$ relatados por Wang et al. (1998). As isoflavonas são solúveis em água e assim na etapa de lavagem do precipitado isoelétrico elas são perdidas, causando uma grande diminuição do teor final do isolado. A diferença no resultado nessa etapa do processo foi a utilização da água de lavagem acidificada ( $\mathrm{pH} 4,5)$, pois em $\mathrm{pH} 4,5$ temos uma diminuição da solubilidade das isoflavonas, como posteriormente observado (Figura 13).

O teor de isoflavonas encontrado nos primeiros isolados (48 a $80 \mathrm{mg} / 100 \mathrm{~g}$ ) foi inferior ao obtido no isolado VII (90 mg/100 g). Tanto Wang et al. (1998) como Wang \& Murphy (1996) encontraram teores maiores de isoflavonas em relação aos IPS obtidos neste trabalho, de 135 e $161 \mathrm{mg} / 100 \mathrm{~g}$ em base seca, respectivamente. No entanto, o rendimento da obtenção dos isolados foi apenas $17,8 \%$ para o isolado contendo $161 \mathrm{mg}$ isoflavonas/100 g e 28,9 \% para o isolado contendo $135 \mathrm{mg}$ isoflavonas $/ 100 \mathrm{~g}$.

Assim, conclui-se que uma centrifugação mais branda para a separação do precipitado isoelétrico (162 $\mathrm{g} / 2 \mathrm{~min}$ a $25^{\circ} \mathrm{C}$ ), $\mathrm{pH} 9$ de extração, $\mathrm{pH}$ 4,5 de precipitação isoelétrica e a utilização de água acidificada na lavagem do precipitado foram as melhores condições de obtenção do IPS com teor aumentado de isoflavonas.

As Figuras a seguir apresentam o perfil das isoflavonas presentes nas diversas etapas de obtenção do IPS a partir da FDS. 


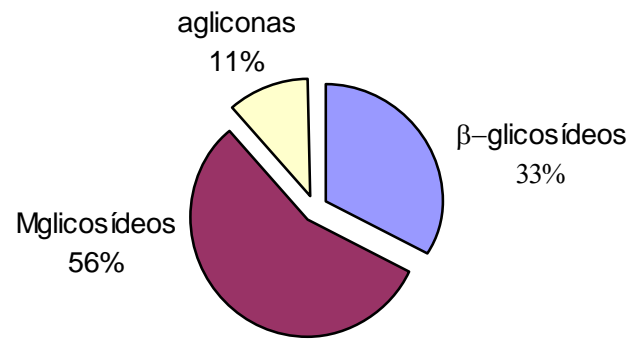

Extrato $\mathrm{pH} 7$ à temp. amb.

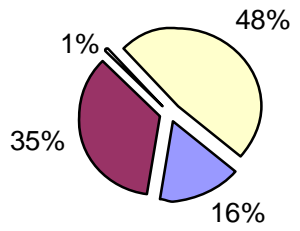

isolado I

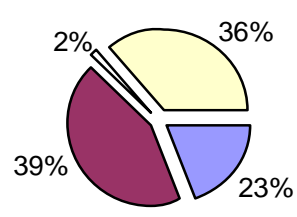

isolado II

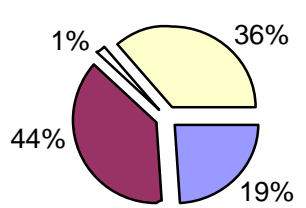

isolado III

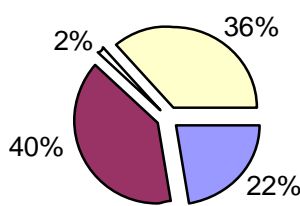

isolado IV

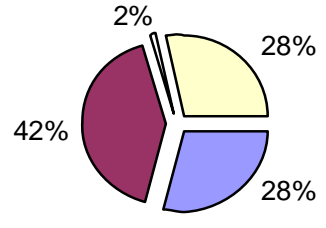

isolado $\mathrm{V}$

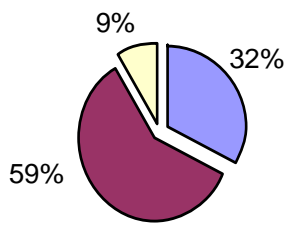

soro ácido I

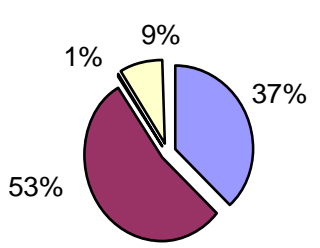

soro ácido II

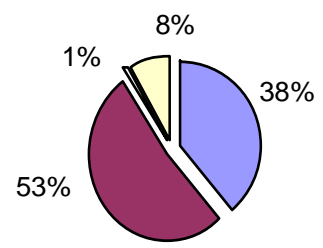

soro ácido III

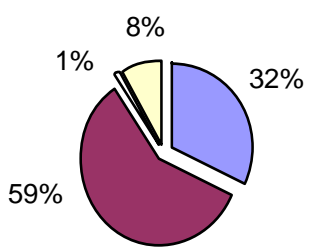

soro ácido IV

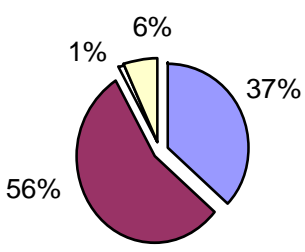

soro ácido V

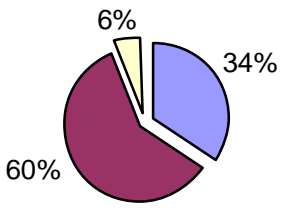

$\mathrm{H}_{2} \mathrm{O}$ lavagem I

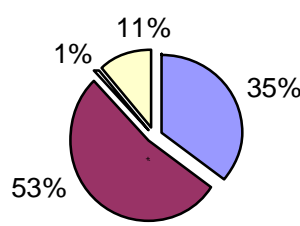

$\mathrm{H}_{2} \mathrm{O}$ lavagem II

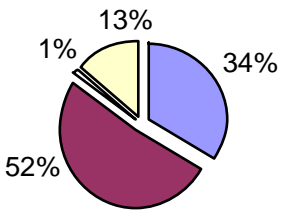

$\mathrm{H}_{2} \mathrm{O}$ lavagem III

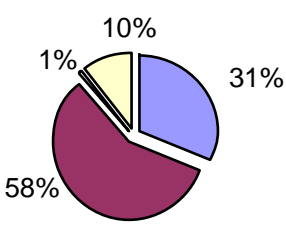

$\mathrm{H}_{2} \mathrm{O}$ lavagem IV

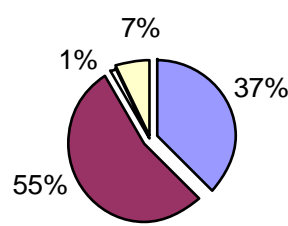

$\mathrm{H}_{2} \mathrm{O}$ lavagem $\mathrm{V}$

$\square$ b-glicosídeos $\square$ Mglicosídeos $\square$ Acglicosídeos $\square$ agliconas

Figura 9. Perfil da distribuição de isoflavonas nas etapas de obtenção dos isolados I, II, III, IV e V. Foram utilizadas as abreviações M e Ac para os radicais malonil e acetil, respectivamente. 


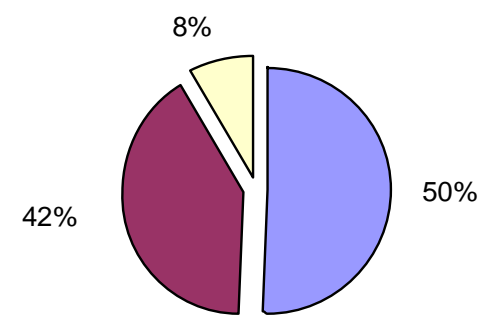

Extrato $\mathrm{pH} 9$ à temp. amb.

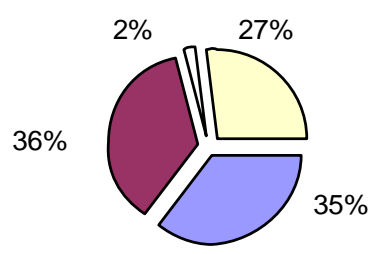

isolado VI

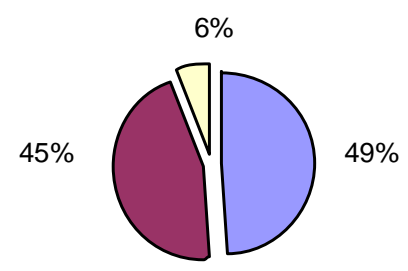

soro ácido VI

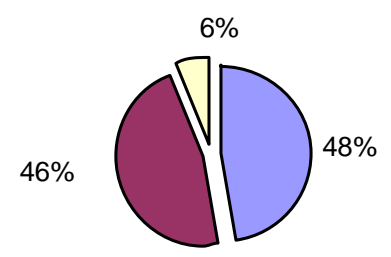

$\mathrm{H}_{2} \mathrm{O}$ lavagem $\mathrm{VI}$

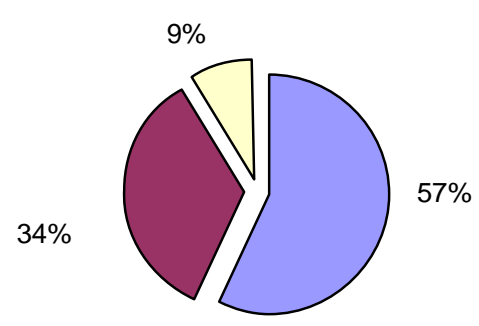

Extrato $\mathrm{pH} 9$ a $55^{\circ} \mathrm{C}$

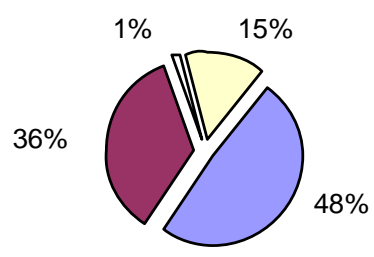

isolado VII

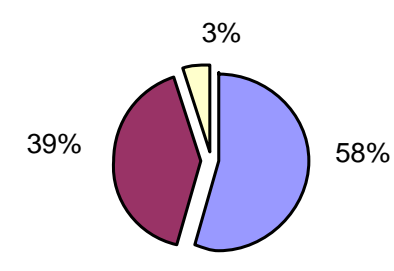

soro ácido VII

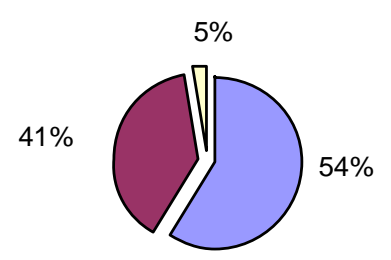

$\mathrm{H}_{2} \mathrm{O}$ lavagem VII

$\square$ b-glicosídeos $\square$ Mglicosídeos $\square$ Acglicosídeos $\square$ agliconas

Figura 10. Perfil da distribuição de isoflavonas nas etapas de obtenção dos isolados VI e VII. Foram utilizadas as abreviações M e Ac para os radicais malonil e acetil, respectivamente. 
$\mathrm{O}$ extrato aquoso obtido em $\mathrm{pH} 7$ (Figura 9) apresentou a maior porcentagem de malonilglicosídeos, e os extratos aquosos obtidos em pH 9 (Figura 10) em $\beta$-glicosídeos, pois em pH alcalino há o favorecimento da reação de desesterificação (Morrison \& Boyd, 1981).

Os isolados I a VI apresentaram grande quantidade de agliconas (27 a $48 \%$ ), porém o isolado VII apresentou-se com baixo teor de agliconas, de apenas $15 \%$. Os IPS I a IV foram obtidos à temperatura ambiente e $\mathrm{pH} 7$, onde se tem ação das $\beta$-glicosidases (Matsuura \& Obata, 1993), que hidrolisam os $\beta$-glicosídeos transformando-os em agliconas, porém em pH 9 a $55{ }^{\circ} \mathrm{C}$, condições usadas na obtenção do isolado VII, as $\beta$-glicosidases tem sua atividade muito reduzida.

Ao se comparar o perfil de isoflavonas da FDS (Tabela 2) com os isolados I a VII (Figuras 9 e 10) pode-se notar que os isolados apresentaram um conteúdo relativamente alto de agliconas, ratificando o trabalho de Wang et al (1998), que encontraram $2 \%$ e $28 \%$ de agliconas para farinha e isolado, respectivamente.

O soro ácido e a água de lavagem acidificada, ambos com $\mathrm{pH} 4,5$, apresentaram o perfil de isoflavonas muito semelhante entre $\mathrm{si}$, com teores altos de malonilglicosídeos e $\beta$-glicosídeos. No entanto, o soro ácido e a água de lavagem acidificada dos isolados extraídos em pH 9 apresentaram uma maior porcentagem de $\beta$-glicosídeos, enquanto as dos isolados extraídos em $\mathrm{pH}$ neutro apresentaram os malonilglicosídeos como principais conjugados (Figuras 9 e 10). Este resultado pode ser explicado pelo fato de que $\mathrm{o}$ pH básico usado na extração favoreceu a reação de desesterificação, aumentando assim os $\beta$-glicosídeos.

Os acetilglicosídeos não aumentaram no processo de obtenção dos IPS, correspondendo a 1 a $2 \%$ das isoflavonas, o que também foi reportado por Wang \& Murphy (1996), pois os IPS 
obtidos foram liofilizados e a produção desses conjugados parece estar relacionada ao calor seco. Na produção dos IPS comerciais o "spray-drying" é utilizado no processo de secagem do isolado, e os conjugados acetilglicosídeos são observados em maiores proporções (Wang \& Murphy, 1994a).

Wang et al. (1998) no processamento do IPS obtiveram um perfil de isoflavonas semelhante entre o soro ácido e a água de lavagem, com alto conteúdo de malonilglicosídeos (75 e $78 \%$, respectivamente). No entanto, a porcentagem de $\beta$-glicosídeos apresentou-se muito reduzida (15\%), diferente do encontrado em nosso trabalho. Isso se deve ao fato de que os autores partiram de uma FDS com elevado conteúdo de malonilglicosídeos e provavelmente as condições brandas utilizadas no processamento do IPS não levaram à desesterificação.

As Figuras 11 e 12 apresentam o perfil da distribuição das formas totais das isoflavonas (daidzeína, genisteína e gliciteína) nas etapas de obtenção dos IPS I a VII. 


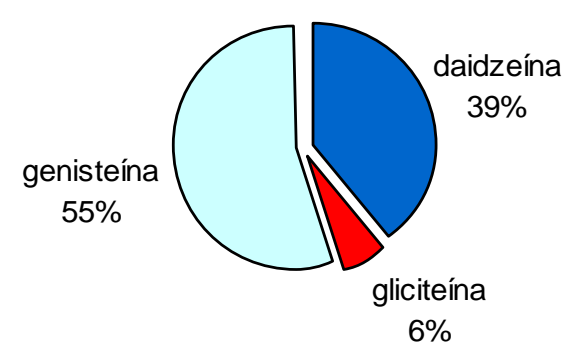

Extrato $\mathrm{pH} 7$ à temp. amb.

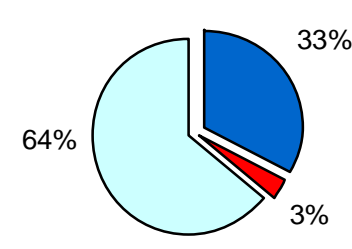

isolado I

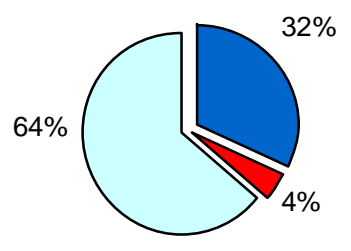

isolado II

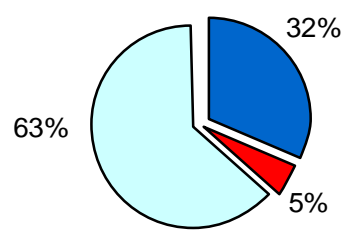

isolado III

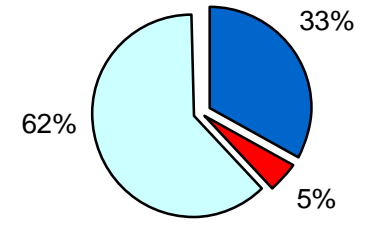

isolado IV

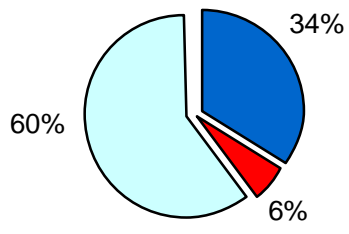

isolado $\mathrm{V}$

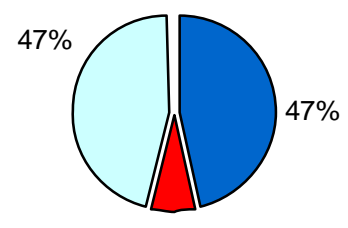

$6 \%$

soro ácido I

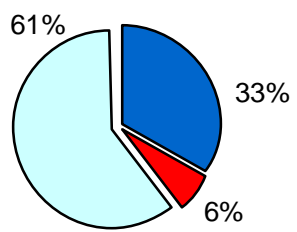

$\mathrm{H}_{2} \mathrm{O}$ lavagem I

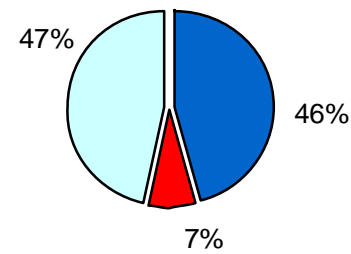

soro ácido II

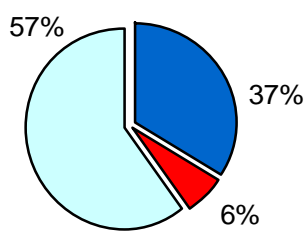

$\mathrm{H}_{2} \mathrm{O}$ lavagem II

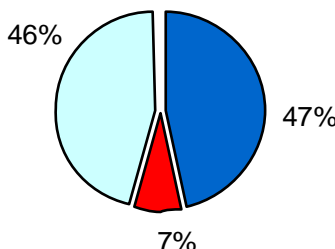

soro ácido III

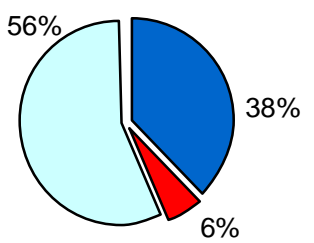

$\mathrm{H}_{2} \mathrm{O}$ lavagem III

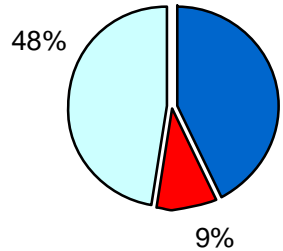

soro ácido IV

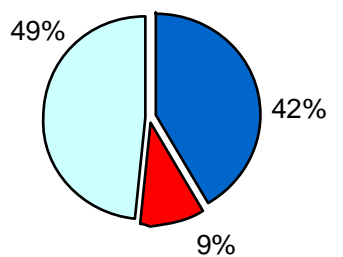

$\mathrm{H}_{2} \mathrm{O}$ lavagem IV

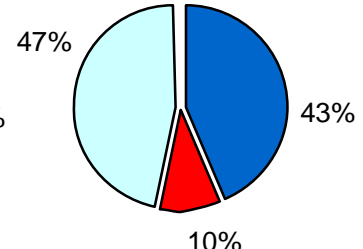

soro ácido V

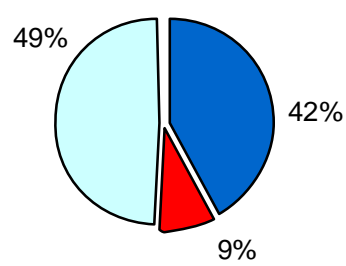

$\mathrm{H}_{2} \mathrm{O}$ lavagem $\mathrm{V}$

$\square$ daidzeína $\square$ gliciteína $\square$ genisteína

Figura 11. Perfil da distribuição das formas totais de isoflavonas (daidzeína, gliciteína e genisteína) nas etapas de obtenção dos isolados I, II, III, IV e V. 


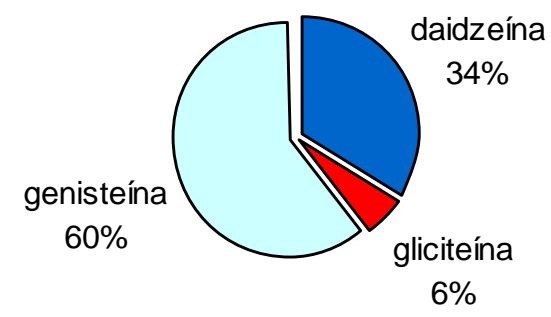

Extrato $\mathrm{pH} 9$ à temp. amb.

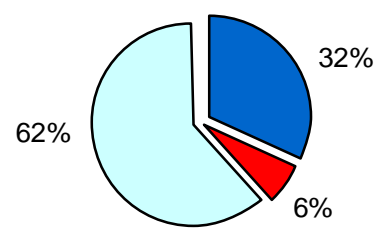

isolado VI

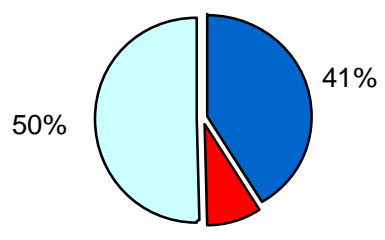

soro ácido VI

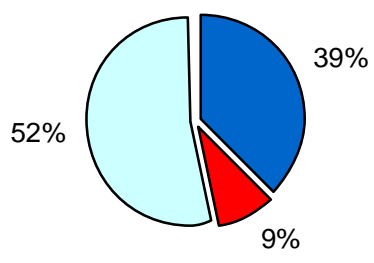

$\mathrm{H}_{2} \mathrm{O}$ lavagem $\mathrm{VI}$

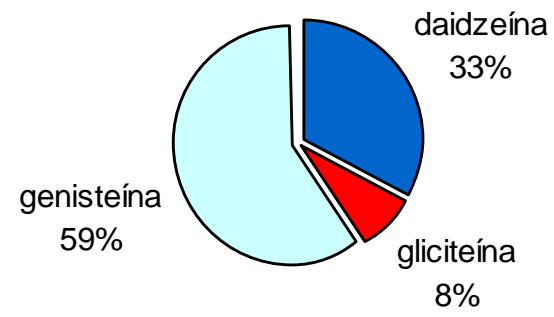

Extrato $\mathrm{pH} 9$ a $55^{\circ} \mathrm{C}$

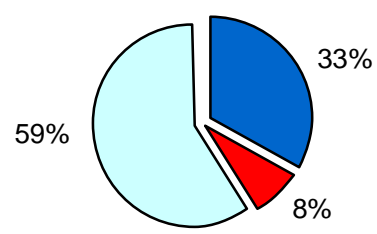

isolado VII

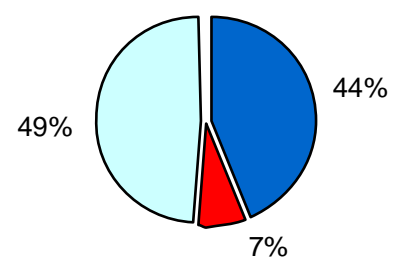

soro ácido VII

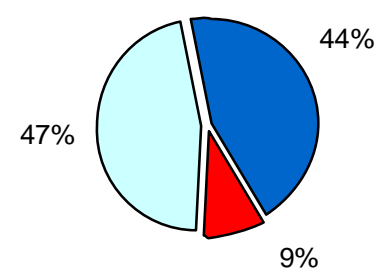

$\mathrm{H}_{2} \mathrm{O}$ lavagem VII

$\square$ daidzeína $\square$ gliciteína $\square$ genisteína

Figura 12. Perfil da distribuição das formas totais de isoflavonas (daidzeína, gliciteína e genisteína) nas etapas de obtenção dos isolados VI e VII. 
Os isolados apresentaram as 3 principais isoflavonas em proporção similar às encontradas na farinha, com maior proporção de genisteína, entre 59 e 64 \% (Figuras 11 e 12).

Os soros ácidos I, II, III e VI apresentaram uma proporção diferente das três isoflavonas em relação à água de lavagem, com maior proporção de genisteína na água de lavagem, como observado por Wang et al. (1998). Além disso, observou-se uma proporção igual de genisteína e daidzeína nos soros ácidos I, II e III. Já os soros ácidos V, VI e VII apresentaram uma proporção das três isoflavonas igual em relação à água de lavagem.

O soro ácido, por outro lado, apresentou quantidade significativamente maior de daidzeína que o isolado e a farinha, indicando que esta seria preferencialmente perdida na obtenção do isolado, também observado por Wang et al. (1998). Uma explicação seria a natureza mais hidrofílica da daidzeína comparada com a genisteína (Coward et al., 1993).

\subsection{Solubilidade das isoflavonas.}

Soluções aquosas das isoflavonas extraídas a partir da FDS tiveram o pH ajustado para valores entre 2 e 10. Após repouso e filtração, a fração solúvel foi analisada e os resultados mostrados na Figura 13. 


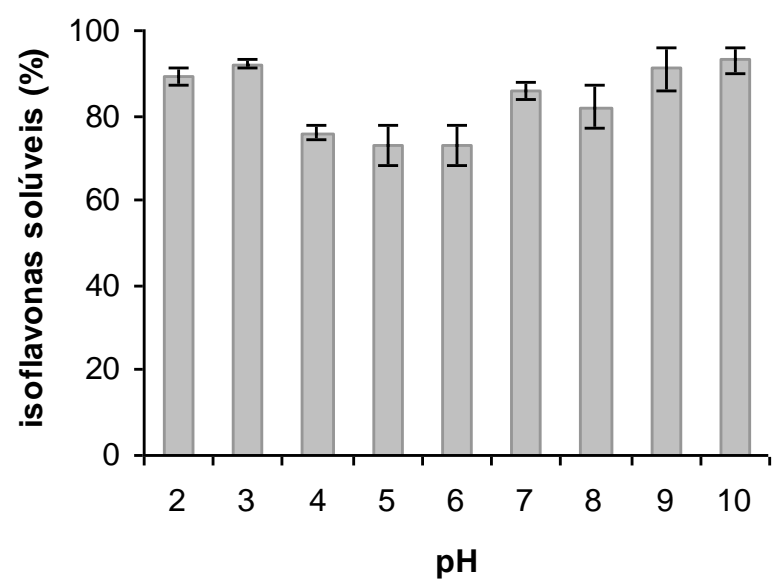

Figura 13. Solubilidade das isoflavonas a partir da farinha desengordurada de soja em diferentes $\mathrm{pH}$.

O controle (100\% solúvel) corresponde à solução metanólica. Os resultados mostraram que as isoflavonas da FDS apresentaram alta solubilidade em solução aquosa em toda a faixa de $\mathrm{pH}$ analisada, exceto em valores entre 4 e 6 . Essa faixa de $\mathrm{pH}$ corresponde também à faixa de menor solubilidade das proteínas da soja.

Em relação ao perfil das isoflavonas (Tabela 14), pode-se notar que com o aumento do $\mathrm{pH}$ a partir de 7, as formas malonilglicosídicas diminuíram com o aumento proporcional dos $\beta$-glicosídeos. As três principais isoflavonas mantiveram sua proporção nos diferentes $\mathrm{pH}$. 
Tabela 14. Perfil da solubilidade das isoflavonas a partir da farinha desengordurada de soja em diferentes $\mathrm{pH}$.

\begin{tabular}{cccccccccc} 
& \multicolumn{7}{c}{ \% de extração } \\
\cline { 2 - 9 } & $\mathbf{p H ~ 2}$ & $\mathbf{p H ~ 3}$ & $\mathbf{p H ~ 4}$ & $\mathbf{p H ~ 5}$ & $\mathbf{p H ~ 6}$ & $\mathbf{p H ~ 7}$ & $\mathbf{p H ~ 8}$ & $\mathbf{p H ~ 9}$ & $\mathbf{p H ~ 1 0}$ \\
\hline$\beta$-glicosídeos & $38 \pm 2^{\mathrm{a}}$ & $40 \pm 1^{\mathrm{a}}$ & $40 \pm 2^{\mathrm{a}}$ & $41 \pm 2^{\mathrm{a}}$ & $41 \pm 2^{\mathrm{a}}$ & $43 \pm 2^{\mathrm{a}, \mathrm{b}}$ & $45 \pm 2^{\mathrm{b}}$ & $51 \pm 1^{\mathrm{c}}$ & $57 \pm 2^{\mathrm{d}}$ \\
Mglicosídeos & $51,8 \pm 0,4^{\mathrm{e}}$ & $50,8 \pm 0,6^{\mathrm{e}}$ & $50,6 \pm 0,5^{\mathrm{e}}$ & $49,2 \pm 0,8^{\mathrm{e}}$ & $50,3 \pm 0,8^{\mathrm{e}}$ & $49 \pm 1^{\mathrm{e}}$ & $47 \pm 1^{\mathrm{f}}$ & $42,3 \pm 0,7^{\mathrm{g}}$ & $36 \pm 2^{\mathrm{h}}$ \\
Acglicosídeos & $1,3 \pm 0,1^{\mathrm{i}}$ & $1,4 \pm 0,1^{\mathrm{i}}$ & $1,5 \pm 0,1^{\mathrm{i}}$ & $1,5 \pm 0,1^{\mathrm{i}}$ & $1,4 \pm 0,1^{\mathrm{i}}$ & $1,2 \pm 0,2^{\mathrm{i}}$ & $1,3 \pm 0,1^{\mathrm{i}}$ & $0,3 \pm 0,1^{\mathrm{j}}$ & $\mathrm{n} \cdot \mathrm{d}$. \\
Agliconas & $8,8 \pm 0,5^{1}$ & $7,9 \pm 0,4^{1}$ & $8,2 \pm 0,1^{1}$ & $7,9 \pm 0,6^{1}$ & $7,8 \pm 0,5^{1}$ & $6,8 \pm 0,1^{\mathrm{m}}$ & $6,9 \pm 0,2^{\mathrm{m}}$ & $6,4 \pm 0,3^{\mathrm{m}}$ & $6,8 \pm 0,5^{\mathrm{m}}$ \\
& & & & & & & & & \\
Daidzeína total & $38 \pm 1^{\mathrm{a}}$ & $38,6 \pm 0,4^{\mathrm{a}}$ & $39 \pm 2^{\mathrm{a}}$ & $40 \pm 3^{\mathrm{a}}$ & $38 \pm 4^{\mathrm{a}}$ & $39 \pm 1^{\mathrm{a}}$ & $40 \pm 5^{\mathrm{a}}$ & $41 \pm 5^{\mathrm{a}}$ & $39 \pm 3^{\mathrm{a}}$ \\
Gliciteína total & $6,3 \pm 0,3^{\mathrm{b}}$ & $5,6 \pm 0,6^{\mathrm{b}}$ & $5,8 \pm 0,3^{\mathrm{b}}$ & $6 \pm 1^{\mathrm{b}}$ & $6 \pm 1^{\mathrm{b}}$ & $6,1 \pm 0,3^{\mathrm{b}}$ & $6,4 \pm 0,8^{\mathrm{b}}$ & $6,4 \pm 0,9^{\mathrm{b}}$ & $6,1 \pm 0,5^{\mathrm{b}}$ \\
Genisteína total & $55 \pm 2^{\mathrm{c}}$ & $55,7 \pm 0,6^{\mathrm{c}}$ & $56 \pm 2^{\mathrm{c}}$ & $54 \pm 4^{\mathrm{c}}$ & $55 \pm 4^{\mathrm{c}}$ & $55 \pm 2^{\mathrm{c}}$ & $54 \pm 4^{\mathrm{c}}$ & $53 \pm 3^{\mathrm{c}}$ & $55 \pm 3^{\mathrm{c}}$
\end{tabular}

Resultados na forma de média \pm desvio-padrão $(n=3)$. n.d. não detectados. Médias na mesma linha com letras diferentes são significativamente diferentes $(p<0,05)$. Foram utilizadas as abreviações $M$ e Ac para os radicais malonil e acetil, respectivamente. 
Estes resultados ajudam a explicar por quê os IPS apresentam conteúdo elevado de isoflavonas. Como a maioria das isoflavonas se encontra na forma glicosilada, isto resulta em uma elevada solubilidade em água, e estas são co-extraídas com as proteínas.

Durante a precipitação isoelétrica das proteínas, as isoflavonas poderiam ser simplesmente carreadas. No entanto, a etapa de lavagem ácida resultaria em sua eliminação quase completa se não houvesse essas outras interações (por exemplo hidrofóbicas) que as mantivessem ligadas às proteínas. A menor solubilidade das isoflavonas em $\mathrm{pH}$ ácido também colaboraria em sua retenção no precipitado.

\subsection{Ação das $\beta$-glicosidases endógenas.}

A partir dos experimentos de otimização da temperatura de extração de proteínas e isoflavonas da FDS foi observado que à temperatura de $50{ }^{\circ} \mathrm{C}$ havia diminuição dos $\beta$-glicosídeos e um aumento das agliconas em relação às demais temperaturas testadas (Tabela 4). Este fato indicou que poderia estar ocorrendo ação das $\beta$-glicosidases endógenas, visto que elas possuem atividade ótima em temperaturas elevadas $\left(45{ }^{\circ} \mathrm{C}\right)$ e atuam na faixa de $\mathrm{pH}$ entre 3 e 7 ( $\mathrm{pH}$ ótimo 5) (Matsuura et al, 1995). Três isoformas da $\beta$-glicosidase ( $A, B$ e $C$ ) foram purificadas a partir dos cotilédones de soja (Matsuura \& Obata, 1993; Matsuura et al., 1995).

Para verificar se as $\beta$-glicosidases estariam agindo durante a extração aquosa da FDS, adicionou-se o substrato sintético específico $p$-nitrofenol- $\beta$-D-glucopiranosídeo ( $p$-NPG), e monitorou- 
se o produto liberado, $p$-nitrofenol, na temperatura ótima da enzima $\left(45^{\circ} \mathrm{C}\right)$ e na temperatura de inativação $\left(60^{\circ} \mathrm{C}\right)$.

Os resultados (Figura 14) mostraram que as $\beta$-glicosidases atuaram sobre o substrato a $45{ }^{\circ} \mathrm{C}$, com aumento de formação de $p$-nitrofenol com o tempo de extração. A $60{ }^{\circ} \mathrm{C}$ não houve formação do produto ( $p$-nitrofenol), confirmando a inativação da enzima nessa temperatura.

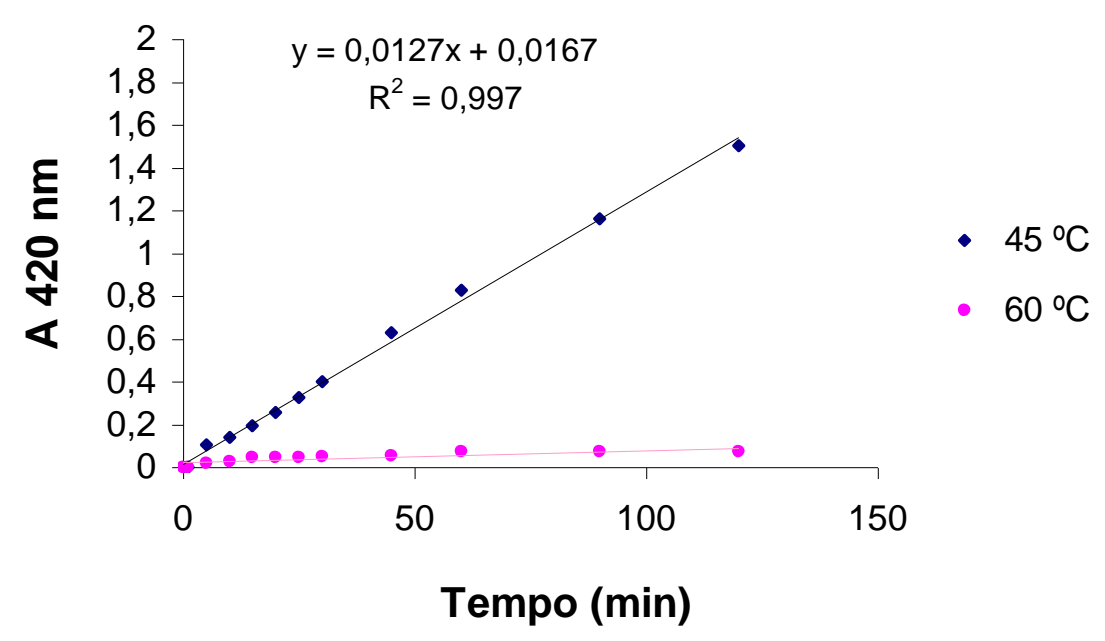

Figura 14. Formação de $p$-nitrofenol a partir da farinha desengordurada de soja extraída em tampão fosfatocitrato $\mathrm{pH} 5$, contendo $0,5 \mathrm{mM} p-\mathrm{NPG}$, a $45^{\circ} \mathrm{C}$ e a $60^{\circ} \mathrm{C}$.

Matsuura \& Obata (1993) analisaram a atividade das $\beta$-glicosidases $B$ e $C$ adicionando $p$-NPG em tampão fosfato-citrato 0,1 M. A $\beta$-glicosidase $B$ apresentou um pH ótimo a 5,5 e a $\beta$-glicosidase $\mathrm{C}$ a $\mathrm{pH} 5$, porém ambas apresentaram atividade na faixa de $\mathrm{pH}$ entre $4,3-7,0$. A temperatura ótima foi $45^{\circ} \mathrm{C}$ e a de inativação de $60{ }^{\circ} \mathrm{C}$ para as $\beta$-glicosidases $\mathrm{B}$ e $\mathrm{C}$, atuando na faixa de $10{ }^{\circ} \mathrm{C}$ a $55{ }^{\circ} \mathrm{C}$. Matsuura et al. (1995) purificaram a 
$\beta$-glicosidase $\mathrm{C}$ e encontraram um pH ótimo ao redor de 4,5 e temperatura ótima de $45^{\circ} \mathrm{C}$. A atividade da enzima foi observada na faixa de $\mathrm{pH} 3,5-7,0$ e de temperatura entre 10 a $50{ }^{\circ} \mathrm{C}$, sendo que $5 \mathrm{~min}$ a $60^{\circ} \mathrm{C}$ foram suficientes para inativar completamente a enzima.

A Tabela 15 mostra o perfil das isoflavonas nos extratos aquosos obtidos a $45^{\circ} \mathrm{C}$ e a $60^{\circ} \mathrm{C}$, na presença e na ausência do $p$-NPG. Observou-se que durante a extração a $45{ }^{\circ} \mathrm{C}$ as $\beta$-glicosidases atuaram hidrolisando os $\beta$-glicosídeos, que sofreram redução de cerca de 50 para $20 \%$ das formas totais, enquanto as agliconas aumentaram de cerca de $9 \%$ para $29 \%$ do total, em relação à temperatura de inativação $\left(60^{\circ} \mathrm{C}\right)$. Os malonilglicosídeos tiveram uma diminuição na temperatura de $60{ }^{\circ} \mathrm{C}$, quando comparados com $45{ }^{\circ} \mathrm{C}$, provavelmente devido à instabilidade desses conjugados em temperaturas elevadas (Kudou et al.,1991; Coward et al., 1993; Barnes et al., 1994).

Quanto aos acetilglicosídeos, não houve uma variação significativa entre as temperaturas testadas e nem nas formas totais das isoflavonas (daidzeína, genisteína e gliciteína) a $45^{\circ} \mathrm{C}$ e a $60{ }^{\circ} \mathrm{C}$, na presença como na ausência do substrato $p$-NPG, sendo a genisteína a isoflavona em maior concentração. 
Tabela 15. Perfil das isoflavonas extraídas a partir da farinha desengordurada de soja em tampão fosfato-citrato $0,1 \mathrm{M}$ $\mathrm{pH} 5$ a $45^{\circ} \mathrm{C}$ e a $60{ }^{\circ} \mathrm{C}$, na presença ou ausência do substrato $p$-NPG, por 3 horas.

\begin{tabular}{ccccc}
\cline { 2 - 4 } & \multicolumn{4}{c}{$\%$ de extração } \\
\cline { 2 - 5 } & $\mathbf{4 5}^{\mathbf{o}} \mathbf{C}$ & $\mathbf{4 5}^{\mathbf{}} \mathbf{C} / \boldsymbol{p}$-NPG & $\mathbf{6 0}^{\mathbf{~}} \mathbf{C}$ & $\mathbf{6 0}^{\mathbf{o}} \mathbf{C} / \boldsymbol{p}$-NPG \\
\hline$\beta$-glicosídeos & $22,2 \pm 0,6^{\mathrm{a}}$ & $20 \pm 1^{\mathrm{a}}$ & $47 \pm 1^{\mathrm{b}}$ & $54,4 \pm 0,8^{\mathrm{c}}$ \\
Mg licosídeos & $48,4 \pm 0,7^{\mathrm{d}}$ & $49 \pm 3^{\mathrm{d}}$ & $40,8 \pm 0,6^{\mathrm{e}}$ & $38 \pm 2^{\mathrm{e}}$ \\
Ac glicosídeos & $1,1 \pm 0,2^{\mathrm{f}}$ & $1,0 \pm 0,1^{\mathrm{f}}$ & $1,0 \pm 0,1^{\mathrm{f}}$ & $1,0 \pm 0,1^{\mathrm{f}}$ \\
Agliconas & $28 \pm 1^{\mathrm{g}}$ & $30 \pm 1^{\mathrm{g}}$ & $11 \pm 1^{\mathrm{h}}$ & $7,0 \pm 0,2^{\mathrm{i}}$ \\
& & & \\
Daidzeína total & $36 \pm 1^{\mathrm{a}}$ & $40 \pm 1^{\mathrm{b}}$ & $37 \pm 1^{\mathrm{a}}$ & $40 \pm 1^{\mathrm{b}}$ \\
Gliciteína total & $5,5 \pm 0,4^{\mathrm{c}}$ & $5,0 \pm 0,1^{\mathrm{c}}$ & $5,9 \pm 0,8^{\mathrm{c}}$ & $6,5 \pm 0,6^{\mathrm{c}}$ \\
Genisteína total & $58 \pm 3^{\mathrm{d}}$ & $55 \pm 1^{\mathrm{d}}$ & $58 \pm 3^{\mathrm{d}}$ & $54 \pm 1^{\mathrm{d}}$ \\
\hline
\end{tabular}

Resultados na forma de média \pm desvio-padrão $(n=3)$. Médias na mesma linha com letras diferentes são significativamente diferentes $(p<0,05)$. Foram utilizadas as abreviações $M$ e Ac para o radical malonil e acetil, respectivamente.

A seguir, verificou-se a ação das $\beta$-glicosidases durante a extração aquosa a pH 7, na presença e na ausência de imidazol. A porcentagem de inibição da atividade das $\beta$-glicosidases de 3 diferentes plantas (Manihot glaziovii, Passiflora foetida, Prunus polystachya) pelo imidazol $5 \mathrm{mM}$ variou de 33 a $80 \%$ enquanto a da glucono-1,5-lactona, nessa mesma concentração, foi de 42 a $68 \%$ (Yeoh \& Wee, 1994). Nos extratos aquosos da FDS obtidos a $45^{\circ} \mathrm{C}$ na presença do inibidor imidazol em concentração de $10 \mathrm{mM}$, encontrou-se um perfil dos conjugados com maior porcentagem de $\beta$-glicosídeos em relação ao extrato aquoso obtido a $45^{\circ} \mathrm{C}$ sem inibidor (Tabela 16). As agliconas tiveram uma redução de $37 \%$ na presença do inibidor, que provavelmente não foi maior por não se tratar de um inibidor específico das $\beta$-glicosidases da soja. 
Matsuura et al. (1989) controlaram a hidrólise dos $\beta$-glicosídeos pelas $\beta$-glicosidases endógenas durante o molho da soja no processamento do leite de soja, adicionando na água glucono-1,5-lactona $0,5 \%(\mathrm{p} / \mathrm{p})$, um inibidor competitivo específico das $\beta$-glicosidases da soja. A produção de daidzeína e genisteína foi inibida pela adição de glucono-1,5-lactona em cerca de $38 \%$ e $55 \%$, respectivamente, após 8 horas de molho.

A porcentagem de malonilglicosídeos dos extratos a $45{ }^{\circ} \mathrm{C}$ (atuação das $\beta$-glicosidases) (Tabela 15) não diminuiu em relação ao extrato na presença do inibidor (Tabela 16) e também entre as temperaturas de $4^{\circ} \mathrm{C}, 25^{\circ} \mathrm{C}$ e $50{ }^{\circ} \mathrm{C}$ (Tabela 4), indicando que as $\beta$-glicosidases não atuariam na molécula de açúcar ligada a um radical. As formas totais das isoflavonas, daidzeína, genisteína e gliciteína, não variaram.

Tabela 16. Perfil das isoflavonas extraídas a partir da farinha desengordura de soja em tampão fosfato-citrato $0,05 \mathrm{M}$ $\mathrm{pH} 7$ na presença e ausência de imidazol $10 \mathrm{mM}$ a $45^{\circ} \mathrm{C}$, por $1 \mathrm{~h}$.

\section{\% de extração}

\begin{tabular}{ccc}
\cline { 2 - 3 } & tampão sem inibidor & tampão na presença do inibidor \\
\hline$\beta$-glicosídeos & $25,9 \pm 0,4^{\mathrm{a}}$ & $36,8 \pm 0,2^{\mathrm{b}}$ \\
Malonilglicosídeos & $55,5 \pm 0,5^{\mathrm{c}}$ & $50,2 \pm 0,8^{\mathrm{d}}$ \\
Acetilglicosídeos & n.d. & n.d. \\
Agliconas & $19 \pm 1^{\mathrm{e}}$ & $13,0 \pm 0,2^{\mathrm{f}}$ \\
& & \\
Daidzeína total & $38 \pm 1^{\mathrm{a}}$ & $35 \pm 2^{\mathrm{a}}$ \\
Gliciteína total & $7 \pm 1^{\mathrm{b}}$ & $8 \pm 1^{\mathrm{b}}$ \\
Genisteina total & $55 \pm 3^{\mathrm{c}}$ & $57 \pm 2^{\mathrm{c}}$
\end{tabular}

Resultados na forma de média \pm desvio-padrão $(n=3)$. n.d. não detectados. Médias na mesma linha com letras diferentes são significativamente diferentes $(p<0,05)$. 
Os extratos aquosos da FDS obtidos nas condições de preparo dos IPS também foram analisados quanto à atuação das $\beta$-glicosidases. Para efeito de comparação, analisaram-se os extratos obtidos em água $\mathrm{pH} 7$ a $45^{\circ} \mathrm{C}$, em tampão fosfato-citrato $\mathrm{pH} 5$ a $45^{\circ} \mathrm{C}$, água pH 7 a $24^{\circ} \mathrm{C}$ e água pH 9 a $55^{\circ} \mathrm{C}$ (Tabela 17).

Tabela 17. Perfil das isoflavonas extraídas a partir da farinha desengordurada de soja em tampão fosfato-citrato $0,1 \mathrm{M}$ $\mathrm{pH} 5$ a $45^{\circ} \mathrm{C}$, em solução aquosa $\mathrm{pH} 7$ a $45^{\circ} \mathrm{C}$, em solução aquosa pH 7 à temperatura ambiente, e em solução aquosa pH 9 a $55^{\circ} \mathrm{C}$, por $24 \mathrm{~h}$.

\% de extração

\begin{tabular}{|c|c|c|c|c|}
\hline & tampão pH 5/45 ${ }^{\circ} \mathrm{C}$ & água pH 7/45 ${ }^{\circ} \mathrm{C}$ & pH $7 / 24^{\circ} \mathrm{C}$ & $\mathrm{pH} \mathrm{9/55^{ \circ } \mathrm { C }}$ \\
\hline$\beta$-glicosídeos & $4,7 \pm 0,9^{\mathrm{a}}$ & $20 \pm 1^{\mathrm{b}}$ & $4,3 \pm 0,5^{\mathrm{a}}$ & $76,1 \pm 0,3^{\mathrm{c}}$ \\
\hline M glicosídeos & $70 \pm 2^{\mathrm{d}}$ & $49 \pm 3^{\mathrm{e}}$ & $61 \pm 2^{\mathrm{f}}$ & $16,4 \pm 0,5^{\mathrm{g}}$ \\
\hline Ac glicosídeos & $1,1 \pm 0,2^{\mathrm{h}}$ & $1,0 \pm 0,1^{\mathrm{h}}$ & n.d. & n.d. \\
\hline Agliconas & $25 \pm 1^{\mathrm{i}}$ & $30 \pm 1^{\mathrm{j}}$ & $35 \pm 1^{1}$ & $7,5 \pm 0,3^{\mathrm{m}}$ \\
\hline Daidzeína total & $46 \pm 1^{\mathrm{a}}$ & $40 \pm 4^{\mathrm{a}}$ & $42 \pm 3^{\mathrm{a}}$ & $45 \pm 1^{\mathrm{a}}$ \\
\hline Gliciteína total & $10 \pm 1^{b}$ & $5 \pm 1^{\mathrm{c}}$ & $9 \pm 1^{b}$ & $8 \pm 1^{b}$ \\
\hline Genisteína total & $44 \pm 1^{\mathrm{d}}$ & $55 \pm 1^{\mathrm{e}}$ & $49 \pm 2^{\mathrm{f}}$ & $47 \pm 1^{\mathrm{f}}$ \\
\hline
\end{tabular}

Resultados na forma de média \pm desvio-padrão $(n=3)$. n.d. não detectados. Médias na mesma linha com letras diferentes são significativamente diferentes $(p<0,05)$. Foram utilizadas as abreviações $M$ e Ac para os radicais malonil e acetil, respectivamente.

Nos extratos aquosos obtidos em pH 7 a $24^{\circ} \mathrm{C}$, em tampão $\mathrm{pH} 5$ a $45^{\circ} \mathrm{C}$ e em água $\mathrm{pH} 7$ a $45{ }^{\circ} \mathrm{C}$ foi observado conteúdo elevado de agliconas e redução de $\beta$-glicosídeos, em relação aos extratos obtidos à temperatura de inativação $\left(60^{\circ} \mathrm{C}\right)$ (Tabela 15$)$ e do extrato obtido na presença do inibidor (Tabela 16). Já em pH 9 
a $55{ }^{\circ} \mathrm{C}$ não houve atuação das $\beta$-glicosidases, evidenciado pelo alto conteúdo de $\beta$-glicosídeos (76 \%) e redução das agliconas. $O$ conteúdo extremamente elevado de $\beta$-glicosídeos foi provavelmente devido à diminuição dos malonilglicosídeos, pois em pH básico há o favorecimento da reação de desesterificação (Morrison \& Boyd, 1981), além do efeito da alta temperatura (Kudou et al.,1991; Coward et al., 1993; Barnes et al., 1994) (Tabela 17). O mesmo pode ser dito ao comparar-se os extratos aquosos ( $\mathrm{pH} 7$ ) obtidos a $24^{\circ} \mathrm{C}$ e a $45^{\circ} \mathrm{C}$, onde o aumento da temperatura de extração foi acompanhado por diminuição dos malonilglicosídeos. No entanto, no extrato obtido em $\mathrm{pH} 5$ observou-se alta proporção de malonilglicosídeos, indicando uma maior termoestabilidade desses compostos em pH ácido.

Os extratos da FDS em tampão pH 5 a $45^{\circ} \mathrm{C}$ e água $\mathrm{pH} 7$ a $45{ }^{\circ} \mathrm{C}$ não tiveram variação dos conjugados acetilglicosídeos e estes não foram detectados nos extratos a pH 7 a $24{ }^{\circ} \mathrm{C}$ e em pH 9 a $55{ }^{\circ} \mathrm{C}$. Contudo, em relação às formas totais das isoflavonas, daidzeína, genisteína e gliciteína, os extratos da FDS obtidos em tampão $\mathrm{pH} 5$ a $45{ }^{\circ} \mathrm{C}$ e em pH 9 a $55^{\circ} \mathrm{C}$ apresentaram uma porcentagem equivalente de genisteína e de daidzeína, enquanto os extratos em água $\mathrm{pH} 7$ a $45{ }^{\circ} \mathrm{C}$ e a $24{ }^{\circ} \mathrm{C}$ apresentaram genisteína em maior concentração (Tabela 17).

Pandjaitan et al. (2000) estudaram a hidrólise da isoflavona glicosídica genistina para sua correspondente aglicona genisteína e observaram que ocorria hidrólise completa de forma estequiométrica. Porém, esses resultados foram obtidos com as isoflavonas purificadas $e$ as $\beta$-glicosidases purificadas foram adicionadas e incubadas na temperatura e pH ótimos $\left(50{ }^{\circ} \mathrm{C}\right.$ e $\mathrm{pH} 5$, respectivamente). No entanto, os pesquisadores também notaram que embora a FDS contenha $\beta$-glicosidases endógenas, a conversão da genistina para genisteína foi menor na preparação do 
concentrado protéico de soja sem adição da enzima exógena. Esses resultados confirmam os aqui obtidos, onde mesmo após 24 horas de extração as $\beta$-glicosidases endógenas não converteram todas as isoflavonas glicosídicas não esterificadas em agliconas (Tabela 17).

\subsection{Estudo da interação entre isoflavonas e proteínas.}

Para estudar possíveis interações entre proteínas e isoflavonas, utilizou-se um isolado protéico de soja comercial, cujos teores de umidade, proteínas, e isoflavonas são apresentados na Tabela 18.

Tabela 18. Teores de umidade, proteínas e isoflavonas do isolado protéico de soja comercial.

\begin{tabular}{c|c}
\hline & Média $\pm \mathrm{DP}$ \\
\hline Umidade $(\mathrm{g} / 100 \mathrm{~g})$ & $3,5 \pm 0,1$ \\
Proteínas $(\mathrm{g} / 100 \mathrm{~g})$ & $94 \pm 4$ \\
Isoflavonas totais* $(\mathrm{mg} / 100 \mathrm{~g})$ & $136 \pm 4$ \\
\hline
\end{tabular}

* O teor de isoflavonas totais foi expresso como agliconas.

A Tabela 19 apresenta o perfil da distribuição das isoflavonas (\% de $\beta$-glicosídeos, \% de malonilglicosídeos, \% de acetilglicosídeos, e \% de agliconas), e a porcentagem total das três isoflavonas presentes (daidzeína, genisteína e gliciteína) observados no IPS comercial, extraídas com MeOH $80 \%$. 
Tabela 19. Perfil das isoflavonas extraídas a partir do isolado protéico de soja comercial em $\mathrm{MeOH}$ 80\%.

\begin{tabular}{cc}
\hline & $(\boldsymbol{\%})$ \\
\hline$\beta$-glicosídeos & $17,8 \pm 0,2$ \\
Malonilglicosídeos & $40,2 \pm 0,2$ \\
Acetilglicosídeos & $3,4 \pm 0,2$ \\
Agliconas & $38,6 \pm 0,4$ \\
& \\
Daidzeína total & $26 \pm 1$ \\
Gliciteína total & $5,8 \pm 0,8$ \\
Genisteína total & $68 \pm 3$ \\
\hline Resultados na forma de média \pm desvio-padrão $(\mathrm{n}=3)$
\end{tabular}

O IPS comercial analisado apresentou um alto conteúdo de agliconas e de malonilglicosídeos (Tabela 19), assim como os IPS I a IV obtidos no laboratório (Figura 9). Das três isoflavonas presentes, a mais abundante foi a genisteína, assim como em todos os IPS obtidos no laboratório (Figuras 11 e 12).

Os resultados estão de acordo com Genovese \& Lajolo (2001a) que encontraram no IPS, extraído por 2 horas em $\mathrm{MeOH} 80 \%$, quantidades maiores de agliconas e malonilglicosídeos e menores de acetilglicosídeos e $\beta$-glicosídeos, e uma semelhança muito grande com os resultados aqui obtidos em relação à porcentagem das três isoflavonas presentes.

Wang \& Murphy (1994a) encontraram um perfil de isoflavonas muito diversificado em três IPS obtidos de fontes comerciais diferentes. O IPS-A tinha um alto conteúdo de agliconas (41 \%) e porcentagem igual de malonilglicosídeos e $\beta$-glicosídeos (ao redor de $27 \%$ ), os IPS-B e C apresentaram baixo conteúdo de agliconas $(7 \%)$ e de malonilglicosídeos (ao redor de 15\%), porém 
alto conteúdo de $\beta$-glicosídeos (44\% e $58 \%$, respectivamente para IPS-B e C) e de acetilglicosídeos (34 \% e $20 \%$, respectivamente para IPS-B e C). $\mathrm{O}$ alto conteúdo de acetilglicosídeos pode ser devido à utilização da farinha tostada de soja como matéria-prima na obtenção do IPS ou alta temperatura na secagem do IPS ("spray-drying"), segundo os próprios autores.

O cromatograma obtido por CLAE do IPS comercial mostrou que os maiores picos correspondem exatamente às agliconas e aos malonilglicosídeos, sendo que os três picos finais correspondem às três agliconas (daidzeína, gliciteína e genisteína), e os picos 3 e 5 a malonilglicitina e malonilgenistina, respectivamente (Figura 15).

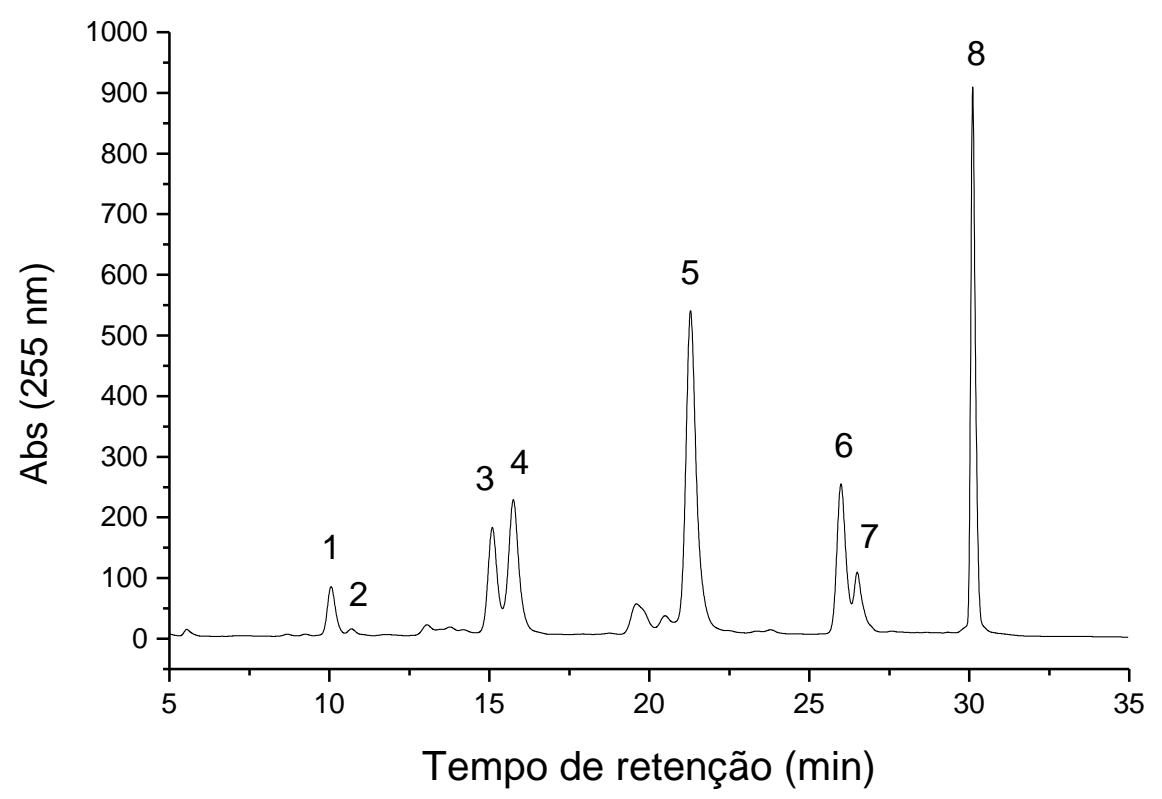

Figura 15. Cromatograma obtido por CLAE do isolado protéico de soja comercial. Solvente $A$ : ácido acético $0,1 \%$ em água; solvente $\mathrm{B}$ : ácido acético $0,1 \%$ em acetonitrila. A fase móvel consistiu em gradiente linear de acetronitrila em fluxo de $1 \mathrm{~mL} / \mathrm{min}$. 1 . daidzina, 2 . glicitina, 3 . malonildaidzina, 4. genistina, 5. malonilgenistina, 6 . daidzeína, 7. gliciteína, 8. genisteína. 
A Tabela 20 mostra a capacidade de diferentes meios extratores de solubilizar isoflavonas e proteínas a partir do IPS comercial. Através desta análise objetivou-se verificar eventuais interações entre isoflavonas e proteínas.

Os resultados mostraram maior solubilidade protéica em soluções aquosas a pH 8 a 10; solução de SDS $1 \%$; e em solução de $\beta$-ME 0,2 M (73 a $85 \%$ ). As isoflavonas, por outro lado, apresentaram maior solubilização em solução aquosa a pH 2 e 10 e soluções de Triton X-100 0,5 e 1 \% (89 a 121 \%). Na região de pH próximo ao ponto isoelétrico, observou-se redução significativa da solubilidade das isoflavonas, conforme anteriormente verificado (Figura 13). 
Tabela 20. Solubilização de isoflavonas e proteínas a partir de isolado protéico de soja em água, em diferentes $\mathrm{pH}$, concentrações de $\mathrm{NaCl}, \beta-\mathrm{ME}$, SDS e Triton X-100.

\begin{tabular}{cccccc}
\hline & $\begin{array}{c}\text { Isoflavonas } \\
\text { solúveis } \\
(\%)\end{array}$ & $\begin{array}{c}\text { Proteínas } \\
\text { solúveis } \\
(\%)\end{array}$ & $\begin{array}{c}\text { Razão } \\
\text { isoflavona total/genisteína total/ } \\
\text { aglicona }\end{array}$ & $\begin{array}{c}\text { Razoflavonas/ } \\
\text { daidzeína total } \\
\text { (mg isofl/ 100g prot) }\end{array}$ \\
\hline $\mathrm{H}_{2} 0$ & 70 & 57,6 & 2,6 & 2,7 & 174 \\
pH 2 & 91 & 63,0 & 3,0 & 2,2 & 209 \\
pH 3 & 45 & 32,0 & 2,0 & 2,1 & 205 \\
pH 4 & 29 & 1,3 & 5,7 & 1,7 & 3173 \\
pH 4,5 & 34 & 1,5 & 6,8 & 1,4 & 3350 \\
pH 5 & 46 & 3,0 & 7,9 & 2,0 & 2251 \\
pH 6 & 68 & 36,0 & 4,3 & 2,3 & 270 \\
pH 7 & 77 & 55,4 & 3,2 & 3,1 & 200 \\
pH 8 & 69 & 73,0 & 2,4 & 2,5 & 137 \\
pH 9 & 72 & 75,0 & 2,0 & 2,6 & 138 \\
pH 10 & 121 & 73,8 & 2,8 & 2,5 & 237 \\
NaCl 0,05 M & 71 & 29,8 & 4,8 & 2,1 & 344 \\
NaCl 0,2 M & 51 & 16,7 & 3,9 & 2,0 & 439 \\
NaCl 0,5 M & 51 & 16,1 & 4,2 & 1,9 & 455 \\
SDS 0,1\% & 34 & 34,5 & 0,9 & 2,2 & 142 \\
SDS 1\% & 57 & 85,5 & 1,1 & 2,1 & 97 \\
Triton 0,1\% & 62 & 34,0 & 2,5 & 3,1 & 267 \\
Triton 0,5\% & 89 & 33,2 & 3,1 & 3,0 & 386 \\
Triton 1\% & 105 & 35,0 & 3,5 & 3,0 & 433 \\
$\beta$-ME 0,001M & 60 & 60,9 & 3,0 & 2,6 & 143 \\
$\beta$-ME 0,01M & 59 & 57,0 & 2,1 & 2,8 & 145 \\
$\beta$-ME 0,02M & 65 & 39,5 & 2,2 & 3,1 & 237 \\
$\beta$-ME 0,2 M & 67 & 74,0 & 2,1 & 2,6 & 131 \\
& & & & & \\
\hline IPS & $136 \mathrm{mg} /$ & $94,3 \mathrm{~g} /$ & 3,6 & 2,4 & \\
\hline
\end{tabular}

Em soluções de $\mathrm{NaCl}$ 0,2 M e 0,5 M as proteínas apresentaram valores de solubilidade extremamente baixos, e apenas cerca de $50 \%$ das isoflavonas foram solubilizadas. Em solução de menor força iônica ( $\mathrm{NaCl}$ 0,05 M) observou-se aumento de solubilização de proteínas, acompanhado de aumento de solubilização de isoflavonas, estas atingindo valores similares aos 
obtidos em água. Nas regiões de pH extremos, 2 e 10, a maior solubilidade protéica também foi acompanhada pela maior solubilidade de isoflavonas.

Em relação aos detergentes, pode-se observar que o detergente aniônico dodecil sulfato de sódio (SDS) apresentou efeito diverso do obtido com o detergente não-iônico Triton. O SDS $0,1 \%$ solubilizou cerca de $35 \%$ das proteínas e das isoflavonas presentes, aproximadamente a metade dos valores obtidos em água. O aumento da concentração de SDS resultou em aumento da solubilização de ambas, proteínas e isoflavonas, embora apenas as proteínas tenham atingido valores maiores que $85 \%$ do total. 0 Triton, por sua vez, solubilizou cerca de $34 \%$ das proteínas nas três concentrações analisadas $(0,1 \%, 0,5 \%$ e $1 \%)$, já as isoflavonas tiveram sua solubilização aumentada de $64 \%$ a $105 \%$ conforme aumentou-se a concentração do Triton.

Os detergentes são utilizados para desfazer as interações hidrofóbicas entre proteínas-proteínas ou proteínas-lipídeos. Dessa forma, o papel do SDS é modificar a estrutura terciária, causando a desnaturação protéica (Hjelmeland \& Chrambach, 1981). O Triton não induz alteração conformacional nas proteínas, é ineficiente em quebrar as interações proteínas-proteínas e conserva a estrutura quaternária na maior parte das proteínas, mesmo na presença de concentrações elevadas do detergente (Rocha, 1999).

A razão entre o teor de isoflavonas e o de proteínas solúveis apresentada na Tabela 20 mostra que os três maiores valores, 3350,3173 , e $2251 \mathrm{mg}$ isoflavonas/100 g proteínas, são devidos à baixa \% de proteínas solúveis nos $\mathrm{pH} 4,4,5$ e 5, respectivamente. O menor valor correspondeu à solução de SDS $1 \%(96,8 \mathrm{mg}$ isoflavonas $/ 100 \mathrm{~g}$ proteínas), que solubilizou uma grande quantidade de proteínas e apenas cerca de $57 \%$ das isoflavonas totais. 
Na Tabela 20 são apresentadas também as proporções entre as formas totais de genisteína e daidzeína extraídas pelas diferentes soluções. Pode-se observar que estas variaram entre 1,4 e 3,1, demonstrando solubilidade diferencial entre estas. Em geral, a genisteína correspondeu a cerca do dobro da daidzeína total extraída, exceto no pH isoelétrico, onde a proporção cai para 1,4 , e nas soluções de Triton $(\sim 3,0), \beta$-Mercaptoetanol $(2,6$ a 3,1) e soluções aquosas com pH maior ou igual a $7(2,5$ a 3,1$)$. Como observado através de CLAE em fase reversa, todos os derivados de genisteína (malonil, acetil e $\beta$-glicosídeos), e a própria genisteína, apresentam caráter mais apolar que os derivados de daidzeína e gliciteína. Dessa forma, poderia haver uma maior interação entre os derivados de genisteína e as proteínas, o que explicaria o fato de que soluções que provocam maior solubilização de proteínas também resultam em maior solubilização destas.

A maior razão isoflavonas totais/agliconas ocorreu nas soluções a pH 4, 4,5, 5, e 6, nas soluções de $\mathrm{NaCl} 0,2 \mathrm{M}$ e 0,5 M, e na solução de Triton X-100 $1 \%$. Os menores valores foram nas soluções de SDS 0,1 e $1 \%$, onde se obteve uma grande porcentagem de agliconas e baixa porcentagem de malonilglicosídeos.

Os resultados da eficiência de extração de isoflavonas e de proteínas nos diferentes $\mathrm{pH}$ analisados, tanto para a FDS como para o IPS comercial, foram resumidos nas Figuras 16 e 17, respectivamente.

De modo geral, o perfil de extração de isoflavonas de acordo com o pH foi similar para a FDS e o IPS. Na extração aquosa em $\mathrm{pH} 2$ e 10 obtiveram-se os maiores rendimentos de isoflavonas a partir do IPS comercial, já nos demais pH de extração ( $\mathrm{pH} 3$ a 9) os valores foram todos abaixo dos obtidos para a FDS (Figura 16). 


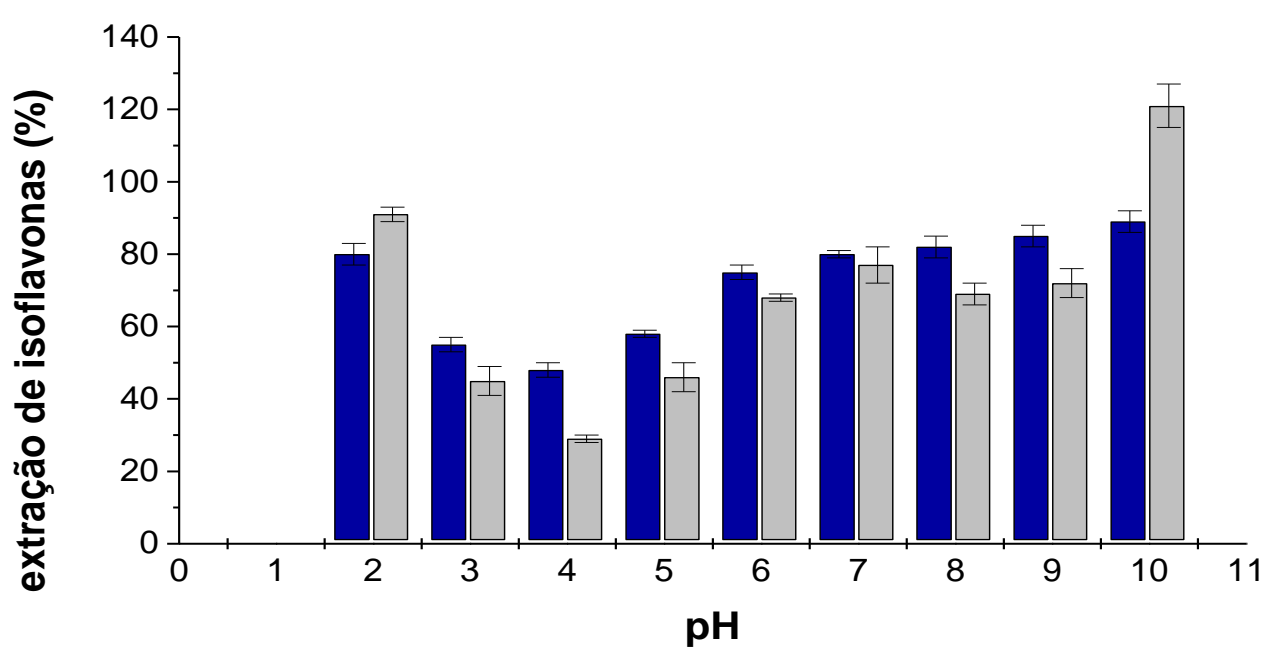

$\%$ de isoflavonas na farinha $\%$ de isoflavonas no isolado

Figura 16. Extração de isoflavonas (\%) por soluções aquosas em diferentes $\mathrm{pH}$ a partir da farinha desengordurada de soja e do isolado protéico de soja comercial.

A Figura 17 mostra o rendimento de extração das proteínas determinado pelo método de micro-Kjeldahl. Assim como observado para as isoflavonas, os perfis obtidos para a FDS e o IPS foram similares entre si. No entanto, observou-se uma maior solubilização das proteínas a partir da farinha em relação ao isolado. Isto pode estar associado ao processo de "spray-drying" ao qual os isolados comerciais são submetidos. 


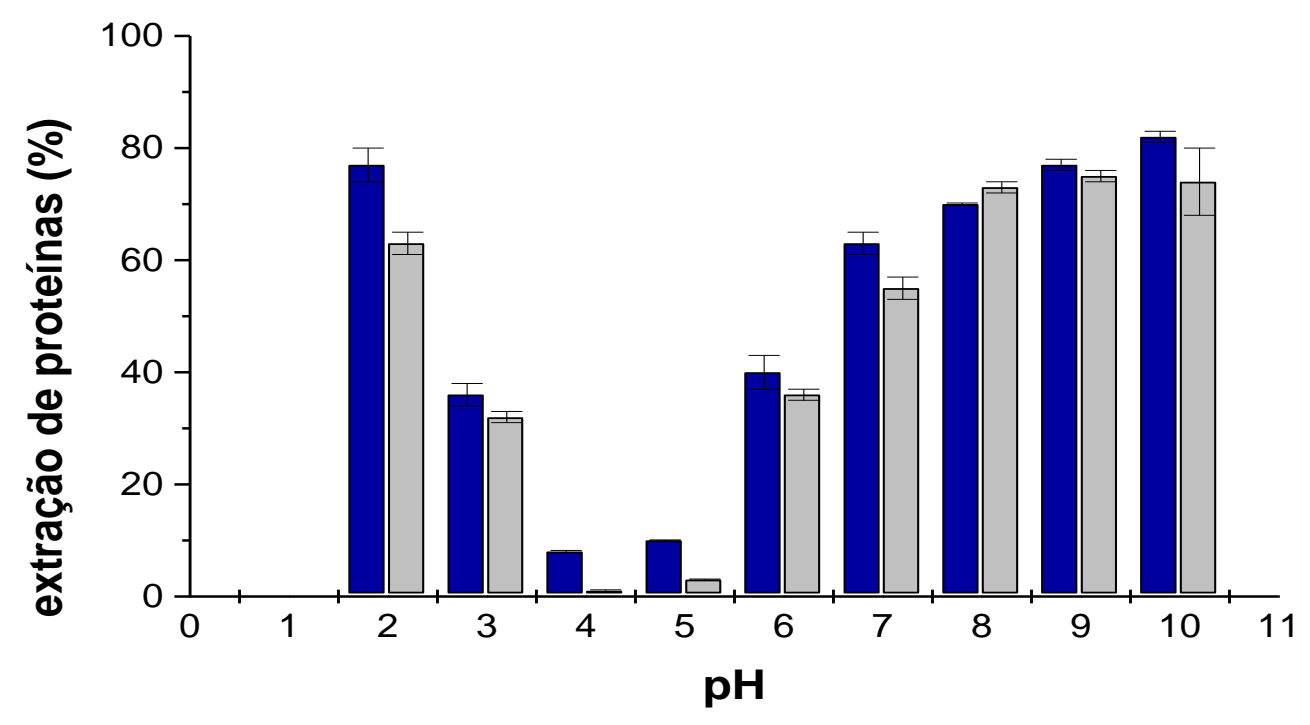

$\%$ de proteínas na farinha $\%$ de proteínas no isolado

Figura 17. Extração de proteínas (\%) por soluções aquosas em diferentes $\mathrm{pH}$ a partir da farinha desengordurada e do isolado protéico de soja comercial (micro-Kjeldahl).

A Figura 18 apresenta os resultados obtidos através de dois diferentes métodos para a determinação de proteínas solúveis, método de Lowry et al. (1951) e micro-Kjeldahl (item 3.4). Embora a variação de solubilidade em função do $\mathrm{pH}$ seja similar medido pelos dois métodos, o de Lowry et al. (1951) apresentou valores significativamente superiores. No método de Lowry et al. (1951) os compostos fenólicos também reagem com o reagente de FolinCiocalteau, levando a uma superestimação do conteúdo protéico (Harris \& Angal, 1989). 


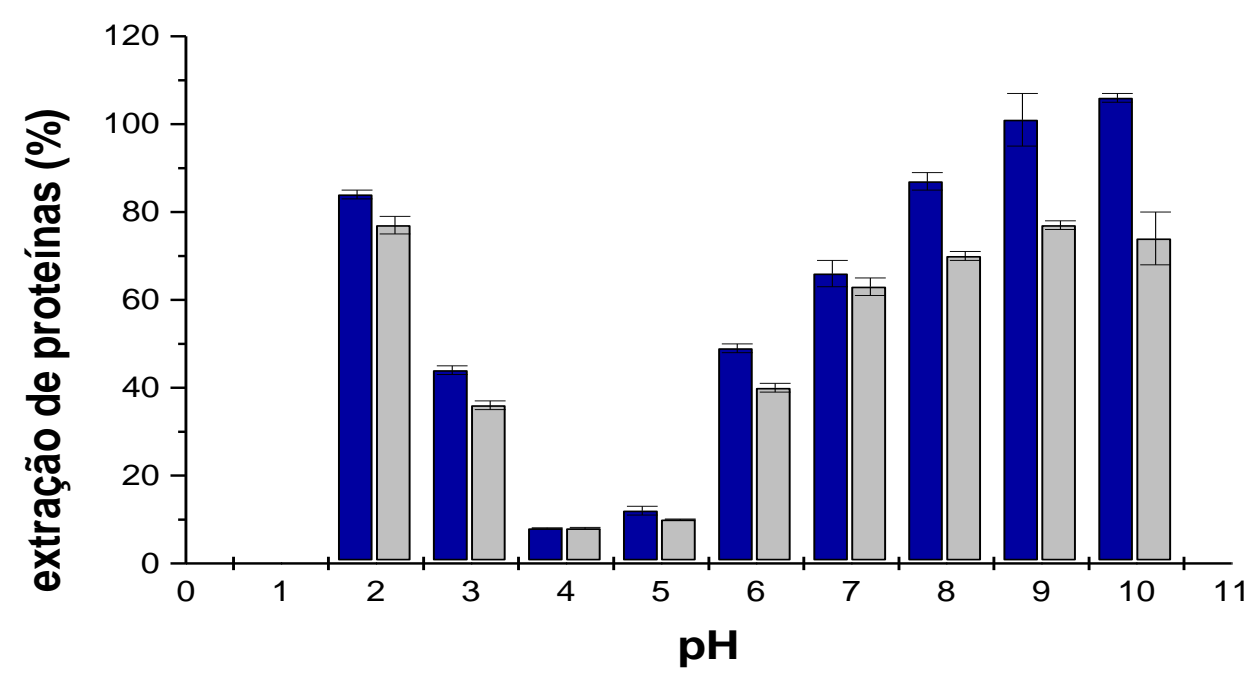

Figura 18. Rendimento protéico a partir da farinha desengordurada de soja determinado através dos métodos de Lowry e de micro-Kjeldahl.

A Tabela 21 mostra o perfil das isoflavonas do IPS comercial solubilizadas em soluções aquosas nos pH 2 a 10, a Tabela 22 em água e em soluções salinas ( $\mathrm{NaCl} 0,05 \mathrm{M} ; 0,2 \mathrm{M}$ e 0,5 M), e a Tabela 23 em soluções de SDS 0,1\% e 1\%, Triton X-100 0,1\%, $0,5 \%$ e $1 \%$, e $\beta$-mercaptoetanol 0,001 M, 0,01 M, 0,02 M, e $0,2 \mathrm{M}$. 
Tabela 20. Perfil das isoflavonas extraídas a partir de isolado protéico de soja comercial em soluções aquosas com pH 2 a 10.

\begin{tabular}{|c|c|c|c|c|c|c|c|c|c|c|}
\hline & \multicolumn{10}{|c|}{ \% de extração } \\
\hline & pH 2 & pH 3 & pH 4 & pH 4,5 & pH 5 & pH 6 & pH 7 & pH 8 & pH 9 & pH 10 \\
\hline$\beta$-glicosídeos & $22 \pm 1^{\mathrm{a}}$ & $33 \pm 2^{b, d}$ & $43 \pm 2^{c}$ & $40 \pm 2^{c}$ & $36 \pm 1^{d}$ & $32 \pm 2^{b}$ & $27 \pm 3^{b}$ & $31 \pm 2^{b}$ & $30 \pm 2^{b}$ & $32 \pm 2^{b}$ \\
\hline Mglicosídeos & $43 \pm 1^{\mathrm{e}}$ & $34 \pm 1^{\mathrm{f}}$ & $38 \pm 1^{g}$ & $44 \pm 1^{\mathrm{e}}$ & $51 \pm 1^{\mathrm{h}}$ & $46 \pm 4^{\mathrm{e}, \mathrm{h}}$ & $40 \pm 2^{\mathrm{e}}$ & $30 \pm 3^{\mathrm{f}}$ & $19 \pm 4^{\mathrm{i}}$ & $21 \pm 1^{\mathrm{i}}$ \\
\hline Acglicosídeos & $1,5 \pm 0,1^{\mathrm{j}}$ & $1,6 \pm 0,4^{\mathrm{j}}$ & $0,9 \pm 0,3^{\mathrm{j}}$ & $0,7 \pm 0,3^{\mathrm{j}}$ & $0,8 \pm 0,5^{\mathrm{j}}$ & $0,7 \pm 0,5^{\mathrm{j}}$ & $2 \pm 1^{j}$ & $0,6 \pm 0,6^{\mathrm{j}}$ & $0,8 \pm 0,3^{j}$ & $1,4 \pm 0,2^{\mathrm{j}}$ \\
\hline Agliconas & $34 \pm 1^{1}$ & $31 \pm 2^{1}$ & $18 \pm 1^{\mathrm{m}}$ & $15 \pm 1^{\mathrm{n}}$ & $13 \pm 1^{\mathrm{n}}$ & $22 \pm 1^{\circ}$ & $31 \pm 2^{1}$ & $39 \pm 1^{p}$ & $50 \pm 4^{\mathrm{q}}$ & $45 \pm 2^{q}$ \\
\hline Daidzeína total & $28 \pm 2^{\mathrm{a}}$ & $30 \pm 2^{\mathrm{a}}$ & $38 \pm 1^{b}$ & $33 \pm 3^{\mathrm{a}}$ & $30 \pm 2^{\mathrm{a}}$ & $29 \pm 1^{\mathrm{a}}$ & $23 \pm 2^{c}$ & $26 \pm 3^{\mathrm{a}}$ & $25 \pm 3^{\mathrm{a}, \mathrm{c}}$ & $27 \pm 3^{\mathrm{a}}$ \\
\hline Gliciteína total & $9 \pm 1^{d}$ & $9 \pm 1^{d}$ & $8 \pm 1^{\mathrm{d}, \mathrm{e}}$ & $10 \pm 1^{\mathrm{d}}$ & $10 \pm 1^{\mathrm{d}}$ & $7 \pm 1^{\mathrm{e}}$ & $5 \pm 2^{\mathrm{e}}$ & $8 \pm 1^{\mathrm{d}, \mathrm{e}}$ & $10 \pm 1^{\mathrm{d}}$ & $4 \pm 3^{e}$ \\
\hline Genisteína total & $62 \pm 3^{\mathrm{f}}$ & $62 \pm 3^{\mathrm{f}}$ & $54 \pm 1^{g}$ & $56 \pm 1^{g}$ & $60 \pm 3^{\mathrm{f}}$ & $65 \pm 2^{\mathrm{f}}$ & $72 \pm 2^{\mathrm{h}}$ & $66 \pm 4^{\mathrm{f}, \mathrm{h}}$ & $66 \pm 5^{\mathrm{f}, \mathrm{h}}$ & $68 \pm 3^{\mathrm{f}, \mathrm{h}}$ \\
\hline
\end{tabular}

Resultados na forma de média \pm desvio-padrão $(n=3)$. Médias na mesma linha com letras diferentes são significativamente diferentes $(p<0,05)$. Foram utilizadas as abreviações $M$ e Ac para os radicais malonil e acetil, respectivamente. 
O perfil das isoflavonas do IPS comercial solubilizadas em soluções aquosas com pH entre 2 e 10 mostrou-se muito variado (Tabela 21). Nos extratos aquosos pH 4 e 4,5 observou-se uma diminuição das agliconas com aumento proporcional dos $\beta$-glicosídeos, e nos pH 5 e 6 têm-se também uma diminuição das agliconas, mas com aumento proporcional dos malonilglicosídeos. Pode-se concluir que as agliconas são pouco solúveis entre os $\mathrm{pH} 4$ a 6 , em relação à quantidade solúvel em água e em extrato metanólico (36 e $38 \%$, respectivamente). Esses resultados indicam que a solubilização das agliconas está mais associada à solubilização protéica.

Os malonilglicosídeos tiveram uma diminuição nos extratos alcalinos $(\mathrm{pH}>7)$, com aumento proporcional das agliconas. $\mathrm{O}$ extrato aquoso $\mathrm{pH} 3$ diferiu de qualquer outro valor de $\mathrm{pH}$, pois apresentou uma proporção média de $33 \%$ entre os $\beta$-glicosídeos, malonilglicosídeos e agliconas.

Quanto aos acetilglicosídeos, não houve uma variação significativa entre os $\mathrm{pH}$ analisados. As formas totais das isoflavonas apresentaram uma pequena variação, com uma diminuição de genisteína e aumento de daidzeína nos pH 4 e 4,5. No entanto, a genisteína foi a isoflavona que se apresentou em maior proporção em todos os pH.

$\mathrm{Na}$ Tabela 22 observa-se o perfil das isoflavonas do IPS comercial solubilizadas em água e em soluções de $\mathrm{NaCl}$ a 0,05 M, $0,2 \mathrm{M}$ e $0,5 \mathrm{M}$. 
Tabela 22. Perfil das isoflavonas extraídas a partir de isolado protéico de soja comercial em água e solução de $\mathrm{NaCl}$ a $0,05 \mathrm{M}, 0,2 \mathrm{M}$ e $0,5 \mathrm{M}$.

\begin{tabular}{ccccc}
\cline { 2 - 4 } & \multicolumn{4}{c}{ \% de extração } \\
\cline { 2 - 4 } & $\mathbf{H}_{\mathbf{2}} \mathbf{O}$ & $\mathbf{0 , 0 5 M}$ & $\mathbf{0 , 2 M}$ & $\mathbf{0 , 5} \mathbf{M}$ \\
\hline$\beta$-glicosídeos & $29 \pm 2^{\mathrm{a}}$ & $29 \pm 1^{\mathrm{a}}$ & $29 \pm 2^{\mathrm{a}}$ & $32 \pm 2^{\mathrm{a}}$ \\
Malonilglicosídeos & $34 \pm 4^{\mathrm{b}}$ & $50 \pm 2^{\mathrm{c}}$ & $53 \pm 1^{\mathrm{c}}$ & $51 \pm 2^{\mathrm{c}}$ \\
Acetilglicosídeos & $1,2 \pm 0,3^{\mathrm{d}}$ & $0,8 \pm 0,3^{\mathrm{d}}$ & $0,7 \pm 0,5^{\mathrm{d}}$ & $0,8 \pm 0,5^{\mathrm{d}}$ \\
Agliconas & $36 \pm 3^{\mathrm{e}}$ & $20 \pm 1^{\mathrm{f}}$ & $18 \pm 2^{\mathrm{f}}$ & $16 \pm 3^{\mathrm{f}}$ \\
& & & \\
Daidzeína total & $26 \pm 1^{\mathrm{a}}$ & $31 \pm 1^{\mathrm{b}}$ & $31 \pm 1^{\mathrm{b}}$ & $32 \pm 1^{\mathrm{b}}$ \\
Gliciteína total & $5 \pm 1^{\mathrm{c}}$ & $5 \pm 1^{\mathrm{c}}$ & $6 \pm 1^{\mathrm{c}}$ & $6 \pm 1^{\mathrm{c}}$ \\
Genisteína total & $69 \pm 1^{\mathrm{d}}$ & $64 \pm 1^{\mathrm{e}}$ & $63 \pm 3^{\mathrm{e}}$ & $62 \pm 2^{\mathrm{e}}$ \\
\hline
\end{tabular}

Resultados na forma de média \pm desvio-padrão $(n=3)$. Médias na mesma linha com letras diferentes são significativamente diferentes $(p<0,05)$.

Pode-se observar que a proporção de $\beta$-glicosídeos ( $29 \%$ do total) solubilizados em solução salina não se diferenciou em relação ao extrato aquoso. No entanto, os malonilglicosídeos apresentaram-se em proporção ( $51 \%$ ) muito maior em soluções salinas do que em água, enquanto as agliconas tiveram uma redução significativa. Quanto aos acetilglicosídeos, não houve uma variação significativa em relação ao extrato aquoso.

Esses resultados mostram que os malonilglicosídeos estariam associados às proteínas através de interações eletrostáticas com os aminoácidos básicos.

A genisteína e seus derivados em água apareceram numa concentração levemente maior do que em soluções salinas.

Os perfis das isoflavonas do IPS comercial solubilizadas na presença do agente redutor $\beta$-mercaptoetanol 0,001 M, 0,01 M, 
0,02 $\mathrm{M}$ e 0,2 M, do detergente aniônico SDS 0,1\% e $1 \%$, e do detergente não-iônico Triton $X-100$ 0,1 \%, 0,5 \% e $1 \%$ foram comparados entre si (Tabela 23 ) e em relação à solução aquosa (Tabela 22).

A porcentagem de $\beta$-glicosídeos (aproximadamente $30 \%$ ) presente nas soluções de $\beta$-ME e dos detergentes aniônicos e nãoiônicos foi similar à do extrato aquoso, exceto para o SDS 0,1\%, com aumento de cerca de $33 \%$. Os malonilglicosídeos tiveram uma drástica redução no extrato de SDS 0,1 e $1 \%$, não sendo detectados na solução de SDS $1 \%$. O aumento das concentrações de Triton $(0,1 \%, 0,5 \%$, e $1 \%)$ resultou em aumento da solubilidade das agliconas e das isoflavonas totais. O aumento da concentração das soluções de $\beta$-ME resultou em diminuição dos malonilglicosídeos, em $13 \%$, em relação ao extrato aquoso.

As soluções de SDS solubilizaram um teor alto de agliconas em relação ao extrato aquoso, e quanto maior a concentração do SDS, maior a porcentagem de agliconas. A maior solubilização de agliconas foi acompanhada por uma maior solubilização de proteínas, o que indicaria a ocorrência de interações hidrofóbicas entre estas, conforme anteriormente mencionado. A solução de $\beta$-ME 0,001 M foi a única que apresentou redução na porcentagem de agliconas em relação aos demais extratos analisados.

Os acetilglicosídeos não foram detectados nos extratos de SDS $0,1 \%$ e $1 \%$ e Triton $0,1 \%$ e $1 \%$. Nas soluções de Triton $0,5 \%$ e $\beta$-ME 0,001 M, 0,01 M, 0,02 M e 0,2 M os acetilglicosídeos não variaram entre si e em relação ao extrato aquoso.

A isoflavona genisteína apresentou-se em maior concentração em todos os extratos analisados. Porém, no extrato em SDS 0,1 e $1 \%$ observou-se uma leve diminuição da genisteína total, com aumento da gliciteína, em relação ao extrato em água. 
Tabela 23. Perfil das isoflavonas do isolado protéico de soja comercial em SDS $0,1 \%$ e $1 \%$, Triton X-100 0,1\%, 0,5 \% e $1 \%$, e $\beta$-ME 0,001 M, 0,01 M, 0,02 M e 0,2 M, no estudo da interação.

\begin{tabular}{cccccccccc} 
& \multicolumn{7}{c}{ \% de extração } \\
\cline { 2 - 9 } & SDS & SDS & Triton & Triton & Triton & $\boldsymbol{\beta}$-ME & $\boldsymbol{\beta}$-ME & $\boldsymbol{\beta}$-ME & $\boldsymbol{\beta}$-ME \\
& $\mathbf{0 , 1 \%}$ & $\mathbf{1 \%}$ & $\mathbf{0 , 1} \%$ & $\mathbf{0 , 5} \%$ & $\mathbf{1 \%}$ & $\mathbf{0 , 0 0 1} \mathbf{M}$ & $\mathbf{0 , 0 1} \mathbf{M}$ & $\mathbf{0 , 0 2} \mathbf{M}$ & $\mathbf{0 , 2} \mathbf{M}$ \\
\hline$\beta$-glicosídeos & $40 \pm 1^{\mathrm{a}}$ & $31 \pm 2^{\mathrm{b}}$ & $30 \pm 1^{\mathrm{b}}$ & $29 \pm 1^{\mathrm{b}, \mathrm{c}}$ & $26 \pm 2^{\mathrm{c}}$ & $32 \pm 2^{\mathrm{b}}$ & $33 \pm 2^{\mathrm{b}}$ & $34 \pm 2^{\mathrm{b}}$ & $31 \pm 1^{\mathrm{b}}$ \\
Mglicosídeos & $8 \pm 2^{\mathrm{d}}$ & n.d. & $36 \pm 1^{\mathrm{e}}$ & $30 \pm 2^{\mathrm{f}}$ & $33 \pm 1^{\mathrm{f}}$ & $39 \pm 1^{\mathrm{g}}$ & $28 \pm 4^{\mathrm{f}, \mathrm{h}}$ & $25 \pm 1^{\mathrm{h}}$ & $26 \pm 2^{\mathrm{f}, \mathrm{h}}$ \\
Acglicosídeos & n.d. & n.d. & n.d. & $1,8 \pm 0,4^{\mathrm{i}}$ & n.d. & $1,3 \pm 0,1^{\mathrm{i}}$ & $1,2 \pm 0,3^{\mathrm{i}}$ & $1,3 \pm 0,2^{\mathrm{i}}$ & $0,7 \pm 0,4^{\mathrm{i}}$ \\
Agliconas & $53 \pm 2^{\mathrm{j}}$ & $70 \pm 1^{\mathrm{k}}$ & $34 \pm 2^{1}$ & $40 \pm 1^{\mathrm{m}}$ & $41 \pm 1^{\mathrm{m}}$ & $27 \pm 2^{\mathrm{n}}$ & $38 \pm 3^{1, \mathrm{~m}}$ & $39 \pm 2^{\mathrm{m}}$ & $43 \pm 2^{\mathrm{m}}$ \\
& & & & & & & & & \\
Daidzeína total & $28 \pm 1^{\mathrm{a}}$ & $29 \pm 3^{\mathrm{a}}$ & $23 \pm 1^{\mathrm{b}}$ & $24 \pm 2^{\mathrm{b}}$ & $23 \pm 2^{\mathrm{b}}$ & $27 \pm 3^{\mathrm{a}, \mathrm{b}}$ & $25 \pm 1^{\mathrm{b}}$ & $23 \pm 2^{\mathrm{b}}$ & $26 \pm 3^{\mathrm{a}, \mathrm{b}}$ \\
Gliciteína total & $8 \pm 1^{\mathrm{c}}$ & $11 \pm 2^{\mathrm{d}, \mathrm{c}}$ & $6 \pm 1^{\mathrm{c}}$ & $5 \pm 2^{\mathrm{c}, \mathrm{e}}$ & $7 \pm 2^{\mathrm{c}}$ & $5 \pm 3^{\mathrm{c}, \mathrm{e}}$ & $5 \pm 3^{\mathrm{c}, \mathrm{e}}$ & $3 \pm 1^{\mathrm{e}}$ & $5 \pm 2^{\mathrm{c}, \mathrm{e}}$ \\
Genisteína total & $64 \pm 1^{\mathrm{f}}$ & $60 \pm 3^{\mathrm{f}}$ & $71 \pm 1^{\mathrm{g}}$ & $71 \pm 3^{\mathrm{g}}$ & $69 \pm 2^{\mathrm{g}}$ & $69 \pm 3^{\mathrm{g}}$ & $70 \pm 2^{\mathrm{g}}$ & $74 \pm 3^{\mathrm{g}}$ & $68 \pm 3^{\mathrm{f}, \mathrm{g}}$
\end{tabular}

Resultados na forma de média \pm desvio-padrão $(n=3)$. n.d. não detectados. Médias na mesma linha com letras diferentes são significativamente diferentes $(p<0,05)$. Foram utilizadas as abreviações $M$ e Ac para os radicais malonil e acetil, respectivamente. 
A Tabela 24 apresenta os teores de isoflavonas livres que estariam presentes no IPS comercial, calculados a partir das Tabelas 20 a 23. Considerou-se como isoflavonas livres aquelas solubilizadas em $\mathrm{pH} 4,5$, isoflavonas totais aquelas solubilizadas em solução de Triton X-100 $1 \%$ e as ligadas ou associadas foram calculadas a partir das isoflavonas solubilizadas nas soluções de $\mathrm{NaCl} 0,2 \mathrm{M}$ e SDS $1 \%$.

Tabela 24. Teor de isoflavonas livres e associadas presentes no isolado protéico de soja comercial.

\begin{tabular}{|c|c|c|c|c|}
\hline $\begin{array}{l}\text { solução } \\
\text { extratora }\end{array}$ & isoflavonas & $\begin{array}{c}\beta \text {-glicosídeos } \\
(\%)\end{array}$ & $\begin{array}{c}\text { malonilglicosídeos } \\
\qquad(\%)\end{array}$ & $\begin{array}{c}\text { agliconas } \\
(\%)\end{array}$ \\
\hline $\mathrm{pH} 4,5$ & livres & 14 & 15 & 5 \\
\hline \multirow[t]{3}{*}{ Triton $1 \%$} & livres & 14 & 15 & 5 \\
\hline & associadas & 12 & 18 & 36 \\
\hline & total & 26 & 33 & 41 \\
\hline \multirow[t]{3}{*}{$\mathrm{NaCl} 0,2 \mathrm{M}$} & livres & 14 & 15 & 5 \\
\hline & associadas & 1 & 12 & 4 \\
\hline & total & 15 & 27 & 9 \\
\hline \multirow[t]{3}{*}{ SDS $1 \%$} & livres & 14 & 0 & 5 \\
\hline & associadas & 3 & 0 & 35 \\
\hline & total & 17 & 0 & 40 \\
\hline
\end{tabular}

Foram consideradas como isoflavonas livres as isoflavonas solubilizadas a partir do IPS comercial em $\mathrm{pH} 4,5$. As isoflavonas totais corresponderam às solubilizadas em solução de Triton X-100 1 \%. 
Os resultados obtidos mostram que cerca de $35 \%$ das isoflavonas presentes nos IPS comerciais estão livres, já que não dependem da solubilização protéica para serem solubilizadas (Tabela 24). Os outros $65 \%$ corresponderiam as isoflavonas ligadas às proteínas e às isoflavonas insolúveis na região do $\mathrm{pH}$ isoelétrico. Considerando-se, a partir de nossos resultados anteriores, que $85 \%$ das isoflavonas solúveis em água permanecem solúveis em pH 4 e 5, $55 \%$ das isoflavonas estariam associadas às proteínas. Entre as isoflavonas associadas às proteínas, cerca de $55 \%$ seriam agliconas, através de interações hidrofóbicas, e cerca de $28 \%$ seriam os malonilglicosídeos, associados através de ligações eletrostáticas.

O detergente aniônico SDS é capaz de solubilizar todas as isoflavonas presentes na forma de agliconas, porém não solubiliza os malonilglicosídeos.

\subsection{Proteínas da soja: Frações 75 e $11 S$.}

Com o intuito de verificar quais frações protéicas estariam envolvidas na possível interação com as isoflavonas e também o de estudar o comportamento das proteínas em diferentes meios extratores realizou-se a análise dos extratos através de eletroforese em condições dissociantes (SDS-PAGE).

Os perfis eletroforéticos (SDS-PAGE $12 \%$ ) dos extratos aquosos obtidos a partir da FDS e das proteínas solubilizadas a partir do IPS comercial por diferentes soluções aquosas são apresentados nas Figuras 19, 20, 21, 23, 24 e 25. 


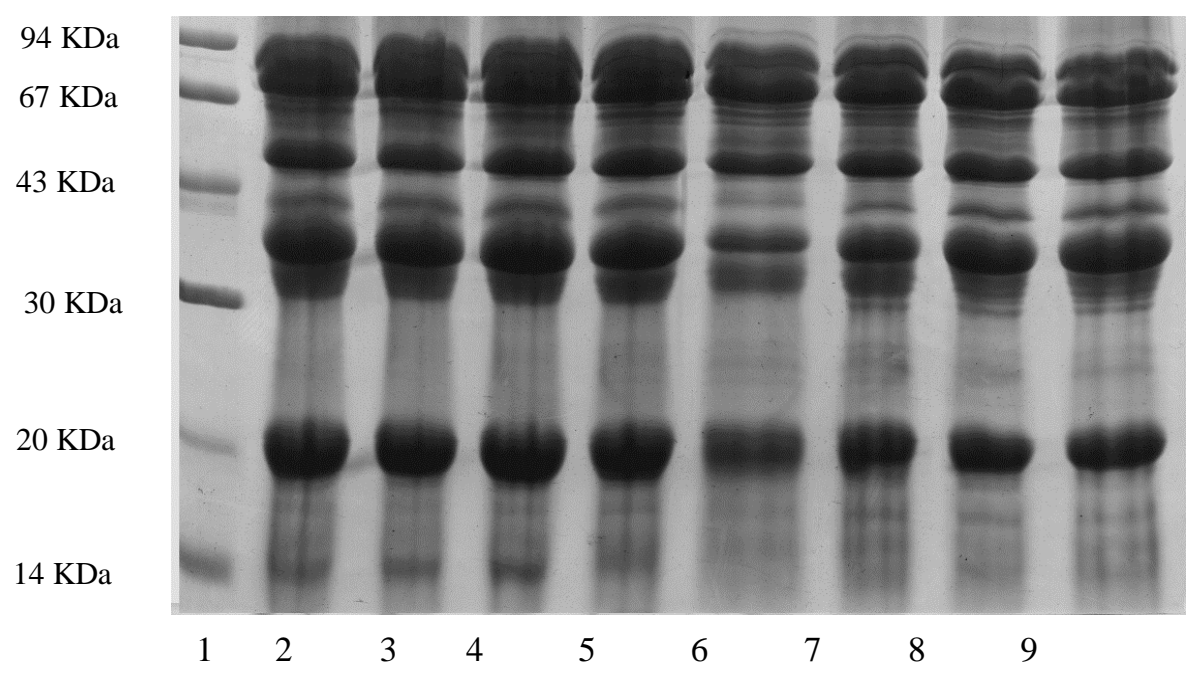

Figura 19. Perfil eletroforético dos extratos aquosos de farinha desengordurada de soja obtidos através de SDS-PAGE $12 \%$, nas seguintes condições: poço (1) padrão de peso molecular, (2) $4{ }^{\circ} \mathrm{C}$, (3) $25{ }^{\circ} \mathrm{C}$, (4) $50{ }^{\circ} \mathrm{C}$, (5) $0,01 \mathrm{M}$ de $\mathrm{NaCl}$, (6) $0,1 \mathrm{M}$ de NaCl, (7) $0,2 \mathrm{M}$ de $\mathrm{NaCl}$, (8) 0,5 M de $\mathrm{NaCl}$ e (9) $1,0 \mathrm{M}$ de NaCl.

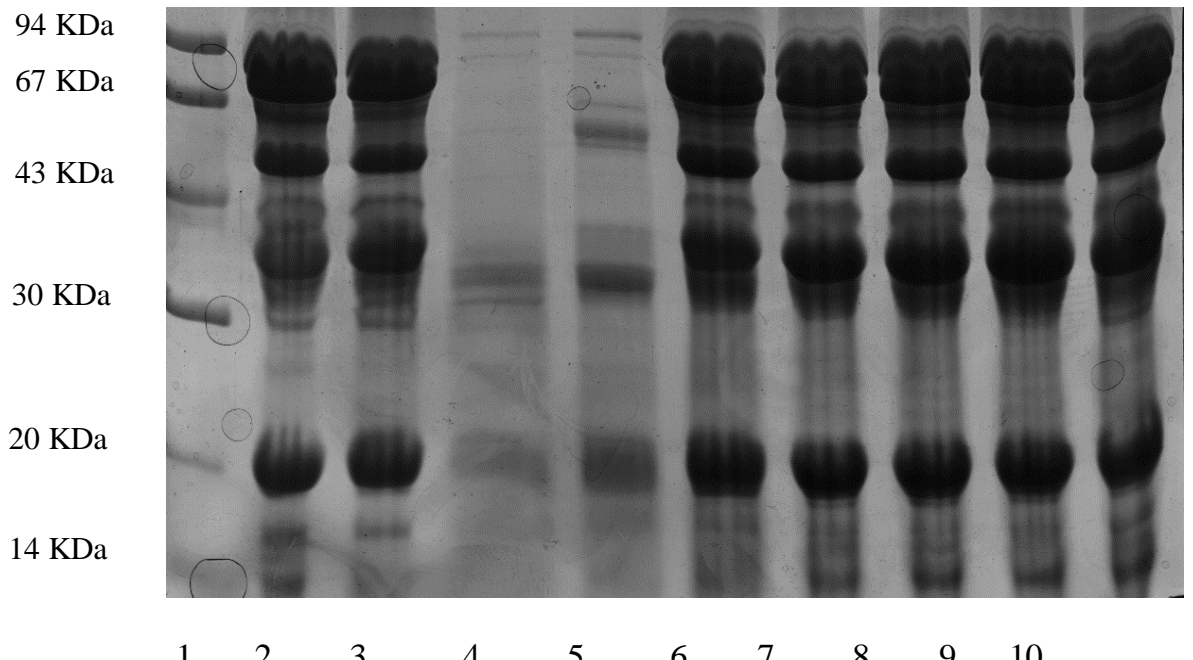

Figura 20. Perfil eletroforético dos extratos aquosos de farinha desengordurada de soja obtidos através de SDS-PAGE $12 \%$, nos seguintes $\mathrm{pH}$ : poço (1) padrão de peso molecular, (2) $\mathrm{pH}$ 2, (3) $\mathrm{pH} 3$, (4) $\mathrm{pH}$ 4, (5) $\mathrm{pH}$ 5, (6) $\mathrm{pH}$ 6, (7) $\mathrm{pH}$ 7, (8) $\mathrm{pH} 8,(9) \mathrm{pH} 9,(10) \mathrm{pH} 10$. 


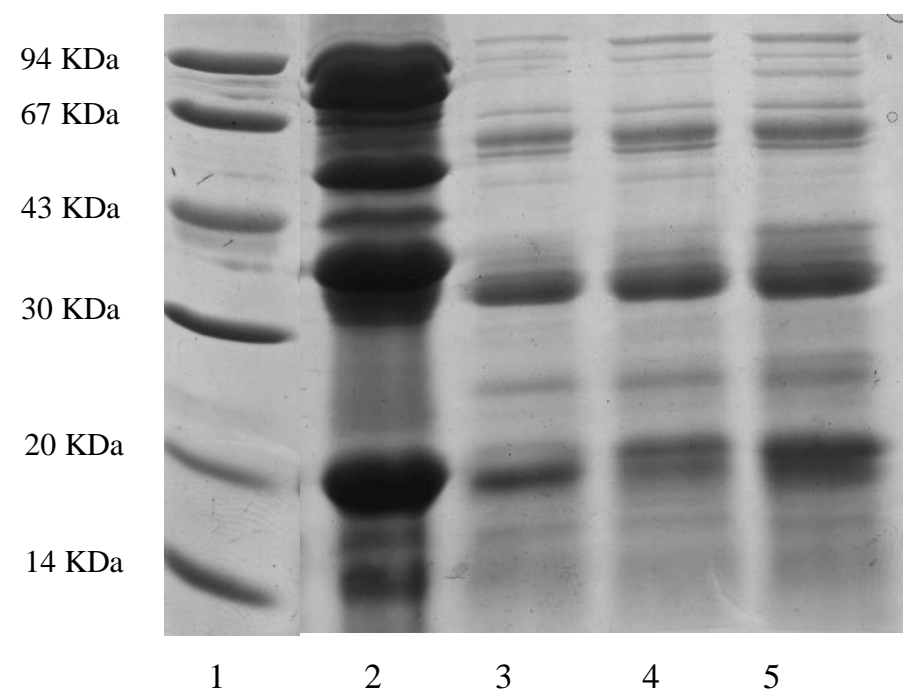

Figura 21. Perfil eletroforético dos extratos aquosos de farinha desengordurada de soja obtidos através de SDS-PAGE $12 \%$. Poço (1) padrão de peso molecular, poço (2) extrato aquoso em $\mathrm{pH} 7$, poço (3) soro ácido $\mathrm{pH} 4$, (4) soro ácido $\mathrm{pH} 4,5$, (5) soro ácido $\mathrm{pH} 5$.

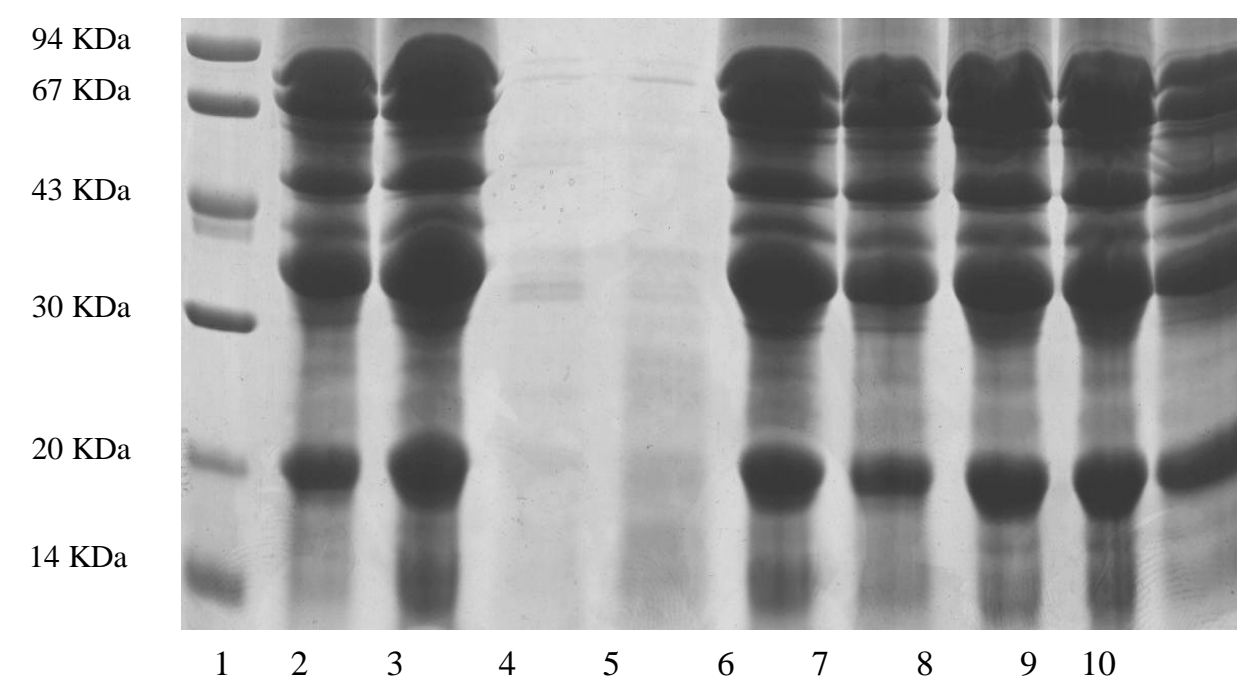

Figura 23. Perfil eletroforético (SDS-PAGE 12\%) das proteínas solubilizadas a partir do isolado protéico de soja em solução aquosa, nos diferentes $\mathrm{pH}$. Poço (1) padrão de peso molecular, (2) $\mathrm{pH} \mathrm{2,} \mathrm{(3)} \mathrm{pH} 3$, (4) $\mathrm{pH} 4$, (5) $\mathrm{pH} 5$, (6) $\mathrm{pH} 6$, (7) $\mathrm{pH}$, (8) $\mathrm{pH}$ 8, (9) $\mathrm{pH}$ 9, (10) $\mathrm{pH} 10$. 


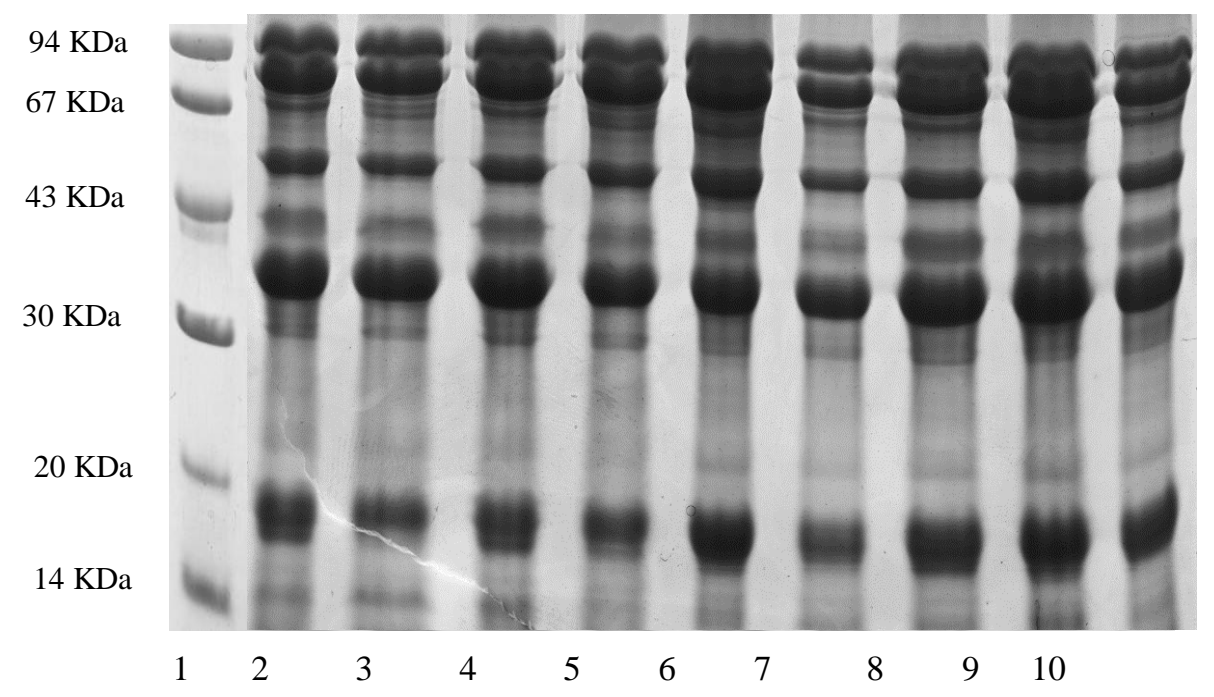

Figura 24. Perfil eletroforético (SDS-PAGE 12\%) das proteínas solubilizadas a partir do isolado protéico de soja, em diferentes soluções. Poço (1) padrão de peso molecular, (2) Triton 0,5\%, (3) Triton $0,1 \%$, (4) Triton $1 \%$, (5) $\beta$-ME 0,001 M, (6) $\beta$-ME 0,01 M, (7) $\beta$-ME 0,02 M, (8) $\beta$-ME 0,2 M, (9) SDS 0,1\%, (10) SDS $1 \%$.

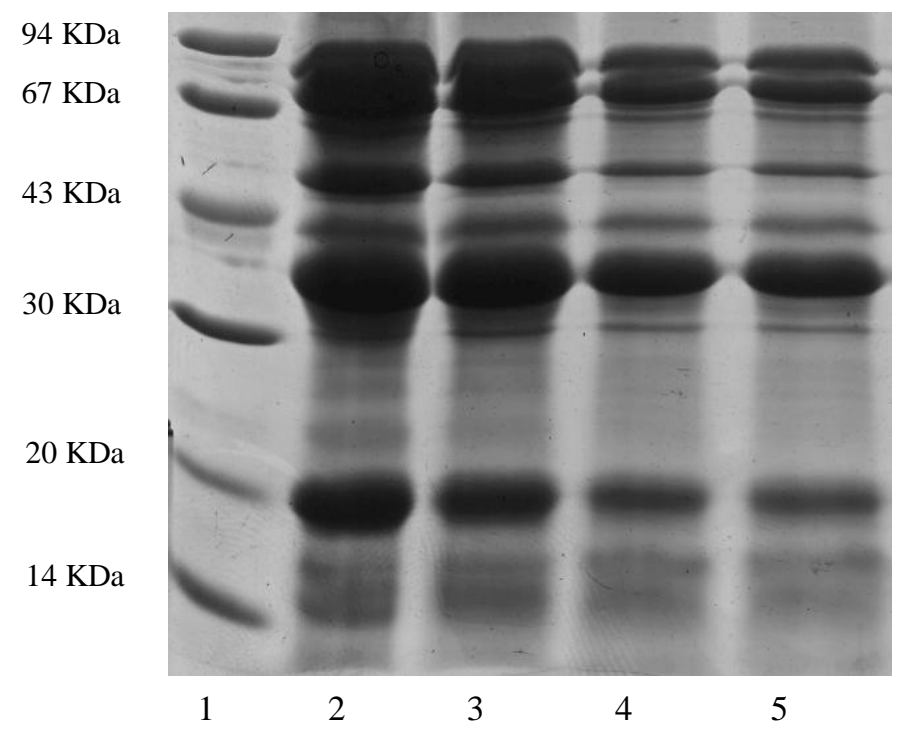

Figura 25. Perfil eletroforético (SDS-PAGE 12\%) das proteínas solubilizadas a partir do isolado protéico de soja, em diferentes soluções. Poço (1) padrão de peso molecular, (2) $\mathrm{H}_{2} \mathrm{O}$, (3) 0,5 M de NaCl, (4) 0,5 M de NaCl, (5) 0,5 M de $\mathrm{NaCl}$. 
As proteínas presentes no IPS comercial e no IPS obtido em laboratório, assim como nas várias etapas de processamento para obtenção do IPS (extratos aquosos, soros ácidos e água de lavagem), também foram analisadas e são apresentadas na Figura 22.

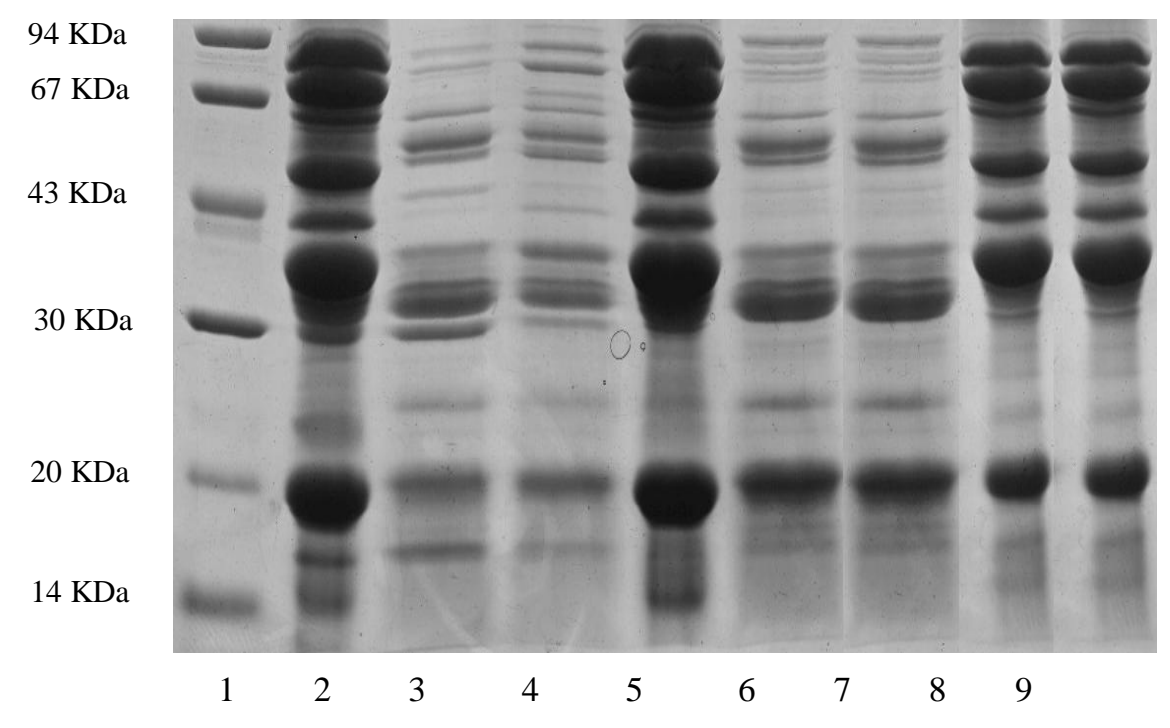

Figura 22. Perfil eletroforético (SDS-PAGE 12\%) das proteínas presentes nas diversas etapas de obtenção dos isolados protéicos de soja. Poço (1) padrão de peso molecular, (2) extrato de FDS em pH 9, (3) soro ácido $\mathrm{pH} \mathrm{4,5,} \mathrm{(4)}$ $\mathrm{H}_{2} \mathrm{O}$ de lavagem, (5) extrato de FDS em pH 7, (6) soro ácido $\mathrm{pH} \mathrm{4,5,} \mathrm{(7)} \mathrm{H}_{2} \mathrm{O}$ de lavagem, (8) IPS comercial e (9) IPS obtido no laboratório. 
Para que se pudesse fazer uma melhor comparação dos perfis eletroforéticos (Figuras 19 a 25), efetuaram-se as análises densitométricas das bandas de interesse as subunidades $\alpha, \alpha^{\prime}$, e $\beta$ (fração 7S), e as subunidades ácidas e básicas, dentre as subunidades ácidas foi realçada a banda A4, um polipeptídeo com PM ao redor de 45.000 Da (fração 11S).

As Tabelas 25 a 28 apresentam as porcentagens obtidas pela análise densitométrica das bandas $\alpha, \alpha^{\prime}, \beta$ da fração 75 e das subunidades ácidas, A4 e básicas da fração 11S.

Tabela 25. Análise densitométrica do perfil eletroforético das frações $7 \mathrm{~S}$ e $11 \mathrm{~S}$ extraídas a partir da farinha desengordurada de soja em solução aquosa a $4{ }^{\circ} \mathrm{C}, 25^{\circ} \mathrm{C}$, $50{ }^{\circ} \mathrm{C}$, em solução de $\mathrm{NaCl} 0,01 \mathrm{M}, 0,1 \mathrm{M}, 0,2 \mathrm{M}, 0,5 \mathrm{M}$, $1,0 \mathrm{M}$, e em solução aquosa a pH 7 .

\begin{tabular}{cccccc}
\hline \multicolumn{3}{c}{ 7S } & \multicolumn{3}{c}{$11 \mathrm{~S}$} \\
\hline$\alpha$ & $\alpha$ & $\beta$ & $\mathrm{A} 4$ & Ácidas & Básicas
\end{tabular}

$(\%)$

(\%)

$(\%)$

$(\%)$

(\%)

(\%)

sol. aq. $4^{\circ} \mathrm{C}$

15,2

18,3

17,9

10,6

18,9

16,9

10,5

19,2

19,0

sol. aq. $25^{\circ} \mathrm{C}$

15,6

18,6

17,4

11,0

18,5

19,3

sol. aq. $50^{\circ} \mathrm{C}$

16,0

19,1

18,0

9,3

18,3

18,9

$\mathrm{NaCl} 0,01 \mathrm{M}$

16,2

21,4

$\mathrm{NaCl} 0,2 \mathrm{M}$

16,1

19,2

20,0

6,9

15,7

19,2

$\mathrm{NaCl} 0,5 \mathrm{M}$

14,9

19,0

19,1

8,1

17,4

19,7

$\mathrm{NaCl} 1,0 \mathrm{M}$

14,6

18,2

18,4

9,7

18,0

20,1

17,6

10,5

19,2

20,0

19,9

sol. aq. pH 7

14,9

17,8

17,3

11,5

18,7

19,8

$\mathrm{Na}$ análise densitométrica das frações $7 \mathrm{~S}$ e $11 \mathrm{~S}$ das proteínas da FDS em solução aquosa a $4{ }^{\circ} \mathrm{C}, 25^{\circ} \mathrm{C}, 50^{\circ} \mathrm{C}$ observou-se que não houve variação na porcentagem das subunidades $\alpha^{\prime}, \alpha, \beta$ da fração 7S e A4, ácidas e básicas da fração 115 (Tabela 25). 
Petruccelli \& Añón (1995a) observaram que os tratamentos térmicos em temperaturas abaixo de $80{ }^{\circ} \mathrm{C}$ não resultaram em diferença significativa do perfil das frações protéicas, confirmando o resultado do nosso trabalho.

As soluções de $\mathrm{NaCl}$ apresentaram porcentagens diferentes das subunidades nas diferentes concentrações utilizadas. A subunidade $\alpha^{\prime}$ diminuiu com o aumento da concentração do sal $(>0,5 \mathrm{M})$, a subunidade $\alpha$ aumentou na solução de $\mathrm{NaCl}$ 0,1 $\mathrm{M}$ e a $\beta$ diminuiu na solução de $\mathrm{NaCl} 1,0 \mathrm{M}$. As subunidades básicas não apresentaram variação (Tabela 25). Em geral, observa-se que o aumento da força iônica da solução extratora leva a um aumento da fração $11 \mathrm{~S}$ e diminuição da $7 \mathrm{~S}$ extraídas.

Petruccelli \& Añón (1995b) relataram que o aumento da concentração de $\mathrm{NaCl}$ diminui a fração $7 \mathrm{~S}$ e consequentemente aumenta a fração 11 S.

Os soros ácidos ( $\mathrm{pH} 4,4,5$ e 5) não apresentaram as subunidades relativas às frações 7 e 11S. Já as proteínas extraídas em solução aquosa a pH 7 à temperatura ambiente apresentaram uma porcentagem similar das frações 7 e $11 \mathrm{~S}$ em relação às soluções aquosas extraídas nas diferentes temperaturas (Tabela 25).

A análise densitométrica das frações $7 \mathrm{~S}$ e $11 \mathrm{~S}$ das proteínas extraídas a partir da FDS em solução aquosa em pH 2 a 10 é apresentada na Tabela 26. 
Tabela 26. Análise densitométrica do perfil eletroforético das frações 75 e $11 S$ extraídas a partir da farinha desengordurada de soja em solução aquosa pH 2 a 10.

\begin{tabular}{ccccccc} 
& \multicolumn{3}{c}{$7 \mathrm{c}$} & & $11 \mathrm{~S}$ & \\
\cline { 2 - 7 } & $\begin{array}{c}\alpha \\
(\%)\end{array}$ & $\begin{array}{c}\alpha \\
(\%)\end{array}$ & $\begin{array}{c}\beta \\
(\%)\end{array}$ & $\begin{array}{c}\text { A4 } \\
(\%)\end{array}$ & $\begin{array}{c}\text { ácidas } \\
(\%)\end{array}$ & $\begin{array}{c}\text { básicas } \\
(\%)\end{array}$ \\
\hline & & & & & & \\
pH 2 & 16,4 & 23,3 & 18,9 & 8,6 & 14,8 & 18,1 \\
pH 3 & 15,1 & 21,2 & 19,1 & 8,6 & 18,5 & 17,6 \\
pH 6 & 13,8 & 20,4 & 19,3 & 8,6 & 18,5 & 19,4 \\
pH 7 & 14,3 & 18,5 & 18,2 & 9,2 & 19,8 & 20,0 \\
pH 8 & 14,8 & 19,0 & 17,8 & 9,4 & 19,8 & 19,2 \\
pH 9 & 15,5 & 19,3 & 17,3 & 10,3 & 19,0 & 18,6 \\
pH 10 & 15,2 & 19,2 & 16,4 & 12,6 & 19,0 & 17,6 \\
\hline
\end{tabular}

Os resultados mostraram um aumento gradual da fração 75 e diminuição da $11 \mathrm{~S}$ com a diminuição do $\mathrm{pH}$, em relação ao $\mathrm{pH} 7$ (Tabela 26). Já em pH básico ( $\mathrm{pH}$ até 10) não houve diferença nas frações 7 e $11 \mathrm{~S}$ em relação ao $\mathrm{pH} 7$.

A análise densitométrica das proteínas solubilizadas a partir do IPS em diferentes soluções mostrou que não há diferença significativa entre a composição das frações solubilizadas em $\mathrm{pH}$ ácido e básico, excetuando-se o pH 10, onde há aumento de $\alpha^{`} \mathrm{e}$ diminuição da subunidade A4 (Tabela 26). Já Petruccelli \& Añón (1995b) não observaram diferença significativa na composição das proteínas em soluções de IPS em pH 7, 8, e 9. Porém, em solução a pH 10 houve um aumento da subunidade ácida da fração 11 S. 
Tabela 27. Análise densitométrica do perfil eletroforético das frações 7S e $11 \mathrm{~S}$ solubilizadas a partir do isolado comercial nas seguintes soluções: água, solução aquosa em pH 2 a 10, Triton X-100 0,5\%, 0,1\%, $1 \%$, $\beta$-ME 0,001 M, 0,01 M, 0,02 M, 0,2 M, SDS 0,1\%, $1 \%$, $\mathrm{NaCl} 0,05 \mathrm{M}, 0,2 \mathrm{M}$ e 0,5 M.

\begin{tabular}{|c|c|c|c|c|c|c|}
\hline & \multicolumn{3}{|c|}{$7 S$} & \multicolumn{3}{|c|}{$11 \mathrm{~S}$} \\
\hline & $\begin{array}{c}\alpha \\
(\%)\end{array}$ & $\begin{array}{c}\alpha \\
(\%) \\
\end{array}$ & $\begin{array}{c}\beta \\
(\%) \\
\end{array}$ & $\begin{array}{l}\text { A4 } \\
(\%)\end{array}$ & $\begin{array}{c}\text { ácidas } \\
(\%)\end{array}$ & $\begin{array}{c}\text { básicas } \\
(\%)\end{array}$ \\
\hline $\mathrm{H}_{2} \mathrm{O}$ & 15,8 & 18,5 & 17,4 & 11,0 & 19,9 & 17,5 \\
\hline pH 2 & 15,9 & 18,3 & 17,1 & 13,5 & 18,2 & 17,0 \\
\hline $\mathrm{pH} 3$ & 15,9 & 17,9 & 16,9 & 14,2 & 18,1 & 17,1 \\
\hline $\mathrm{pH} 6$ & 15,6 & 17,5 & 17,3 & 14,2 & 18,2 & 17,3 \\
\hline pH 7 & 16,4 & 18,9 & 17,6 & 12,8 & 17,4 & 17,0 \\
\hline $\mathrm{pH} 8$ & 15,0 & 18,3 & 17,4 & 13,8 & 17,7 & 17,8 \\
\hline pH 9 & 14,9 & 18,1 & 17,1 & 13,5 & 18,2 & 18,2 \\
\hline $\mathrm{pH} 10$ & 17,6 & 17,9 & 17,0 & 11,8 & 18,5 & 17,2 \\
\hline Triton $0,5 \%$ & 16,8 & 21,4 & 16,9 & 9,3 & 20,2 & 15,4 \\
\hline Triton $0,1 \%$ & 16,1 & 20,4 & 16,2 & 10,6 & 20,3 & 16,4 \\
\hline Triton $1 \%$ & 16,1 & 18,6 & 17,1 & 11,7 & 20,6 & 15,9 \\
\hline$\beta$-ME $0,001 \mathrm{M}$ & 16,6 & 19,9 & 16,9 & 8,9 & 21,5 & 16,1 \\
\hline$\beta$-ME $0,01 \mathrm{M}$ & 15,4 & 18,7 & 16,8 & 11,9 & 18,9 & 18,3 \\
\hline$\beta$-ME $0,02 \mathrm{M}$ & 14,3 & 18,4 & 17,6 & 11,6 & 19,1 & 19,0 \\
\hline$\beta$-ME $0,2 \mathrm{M}$ & 16,1 & 19,5 & 16,6 & 10,5 & 19,8 & 17,4 \\
\hline SDS $0,1 \%$ & 16,1 & 20,5 & 17,1 & 9,9 & 20,8 & 15,6 \\
\hline SDS $1 \%$ & 16,3 & 18,5 & 17,4 & 10,7 & 18,4 & 18,7 \\
\hline $0,05 \mathrm{M} \mathrm{NaCl}$ & 15,8 & 19,0 & 16,4 & 11,2 & 19,9 & 17,6 \\
\hline $0,2 \mathrm{M} \mathrm{NaCl}$ & 16,9 & 20,2 & 12,4 & 10,6 & 23,5 & 16,4 \\
\hline $0,5 \mathrm{M} \mathrm{NaCl}$ & 16,6 & 21,3 & 12,1 & 10,3 & 24,5 & 15,2 \\
\hline
\end{tabular}


As proteínas solubilizadas a partir da FDS e do IPS comercial não diferiram em relação à composição das subunidades das frações 7 e 11S (Tabela 27).

Na solubilização de IPS comercial em Triton X-100 observouse uma diminuição da subunidade $\alpha$ e aumento da A4 com o aumento das concentrações do detergente (Tabela 27).

$\mathrm{Na}$ solução de IPS comercial em $\beta$-mercaptoetanol 0,001 M as subunidades ácidas aumentaram em relação às outras concentrações analisadas $(0,01,0,02$ e 0,2 M). A presença de agente redutor causa tanto desnaturação protéica como redução parcial das pontes dissulfeto das subunidades $A B$ da fração 11S, causando a liberação dos peptídeos ácidos e básicos (Wagner et al., 2000).

A solução de IPS comercial em detergente SDS a $1 \%$ apresentou diminuição da subunidade $\alpha$ e aumento das básicas, em relação ao SDS $0,1 \%$. Já na solução com $0,1 \%$ de SDS observouse aumento das subunidades ácidas (Tabela 27).

Nas soluções de IPS comercial em $\mathrm{NaCl} 0,2 \mathrm{M}$ e 0,5 M observou-se uma diminuição na subunidade $\beta$ e aumento das ácidas em relação à concentração de $0,05 \mathrm{M}$ (Tabela 27). Essa diminuição da subunidade $\beta$ pode ser devido à interação dessa subunidade com a subunidade básica da fração 11 (Utsumi et al., 1984).

A presença de cátion divalente pode induzir agregação por interação iônica, principalmente devido a fração $11 \mathrm{~S}$ possuir o sítio de ligação para cálcio e magnésio (Wagner et al., 2000).

A análise densitométrica das proteínas solubilizadas nas várias etapas do processo de obtenção do IPS, e ainda do IPS comercial e do IPS obtido em laboratório é apresentada na Tabela 28. 
Tabela 28. Análise densitométrica do perfil eletroforético das frações 7S e $11 \mathrm{~S}$ extraídas a partir da farinha desengordurada de soja nas etapas de obtenção do isolado (laboratório), e do isolado comercial.

\begin{tabular}{ccccccc} 
& \multicolumn{3}{c}{$7 \mathrm{c}$} & \multicolumn{3}{c}{$11 \mathrm{~S}$} \\
\cline { 2 - 7 } & $\begin{array}{c}\alpha \\
(\%)\end{array}$ & $\begin{array}{c}\alpha \\
(\%)\end{array}$ & $\begin{array}{c}\beta \\
(\%)\end{array}$ & $\begin{array}{c}\text { A4 } \\
(\%)\end{array}$ & $\begin{array}{c}\text { ácidas } \\
(\%)\end{array}$ & $\begin{array}{c}\text { básicas } \\
(\%)\end{array}$ \\
\hline extrato pH 7 & 14,9 & 17,1 & 17,0 & 13,0 & 18,6 & 19,4 \\
extrato pH 9 & 15,5 & 17,9 & 17,0 & 13,3 & 18,3 & 18,0 \\
& & & & & & \\
IPS laboratório & 14,5 & 18,3 & 16,6 & 12,1 & 20,8 & 17,8 \\
IPS comercial & 14,9 & 18,6 & 17,0 & 12,2 & 19,9 & 17,4 \\
\hline
\end{tabular}

Nas etapas de obtenção do IPS, as proteínas extraídas a partir da FDS nas soluções aquosas a pH 7 e 9 não apresentaram diferenças nas frações 7 e 11S. Enquanto que as bandas protéicas presentes nos soros ácidos e água de lavagem $(\mathrm{pH} 4,5)$ não apresentaram as subunidades relativas às frações 7 e $11 \mathrm{~S}$.

O IPS obtido no laboratório e o IPS comercial apresentaram a mesma proporção das frações 75 e 11S.

A análise densitométrica das proteínas solubilizadas a partir do IPS comercial, por diferentes soluções, mostrou diferenças quantitativas nos perfis eletroforéticos, porém esses dados foram insuficientes para indicar uma associação preferencial com as isoflavonas. 


\section{CONCLUSÕES}

Os resultados deste trabalho mostraram que a obtenção de isolados protéicos de soja com teor aumentado de isoflavonas depende da utilização de condições brandas de centrifugação para a separação do precipitado isoelétrico, assim como da utilização de água acidificada na sua lavagem.

A diferença entre o perfil de isoflavonas presentes na FDS e no IPS é decorrente da atuação de $\beta$-glicosidases endógenas no processo de obtenção dos isolados, resultando em porcentagem mais elevada de agliconas.

A presença de isoflavonas no IPS resultou de três fatores:

$\checkmark$ associação entre isoflavonas e proteínas através de interações hidrofóbicas; ligações eletrostáticas entre a carboxila ionizada dos malonilglicosídeos e os aminoácidos básicos das proteínas; pontes de hidrogênio, como exemplo entre as hidroxilas e carboxilas ( $\mathrm{N}-\mathrm{H}$ e C $=\mathrm{O}$ da ligação peptídica);

$\checkmark$ menor solubilidade das isoflavonas presentes na FDS no $\mathrm{pH}$ isoelétrico;

$\checkmark$ processo de carreamento (físico). 


\section{REFERÊNCIAS BIBLIOGRÁFICAS}

ADLERCREUTZ, H.; GORBACH, S.; GOLDIN, B. Dietary phytoestrogens and the menopause in Japan. Lancet, London, v.339, p.1233, 1992.

ADLERCREUTZ, H.; HONJO, H.; HIGASHI, A.; FOTSIS, T.; HAMALAINEN, E.; HASEGAWA, T.; OKADA, H. Urinary excretion of lignans and isoflavonoid phytoestrogens in Japanese men and women consuming a traditional Japanese diet. Am. J. Clin. Nutr., Bethesda, v.54, p.1093-1100, 1991.

ADLERCREUTZ, H.; VAN DER WILDTZ, J.; KINZEL, J.; ATTALLA, H.; $W \ddot{H} H A ̈ L A ̈, K$. Lignan and isoflavonoid conjugates in human urine. J. Steroid Biochem. Mol. Biol., Amsterdam, v.52, p.97-103, 1995.

AKIYAMA, T.; ISHIDA, J.; NAKAGAVA, S.; OGAWARA, S.; WATANABE, S.; ITOH, N.; SHIYBA, M.; FUKAMI, Y. Genistein, a specific inhibitor of tyrosine-specific protein kinases. J. Biol. Chem., Birmingham, v.262, p.5592-5595, 1987.

ANDERSON, R.L.; WOLF, W.J. Compositional changes in trypsin inhibitors, phytic acid, saponins and isoflavones related to soybean processing. J. Nutr., Bethesda, v.125, n.3, p.581S588S, 1995.

ARABBI, P.R. Alimentos funcionais: aspectos gerais. Nutrire: Rev. Soc. Bras. Alim. Nutr., São Paulo, v.21, p.82-102, 2001. 
ASSOCIATION OF OFFICIAL ANALYTICAL CHEMISTS. Official Methods of Analysis of A.O.A.C. 16.ed. Washington, 1995. 2000p.

BADLEY, R.A.; ATKINSON, D.; HANSER, H.; OLDANI, D.; GREEN, J.P.; STUBBS, J.M. The structure, physical and chemical properties of the soybean protein glycinin. Biochim. Biophys. Acta, Amsterdam, v.412, p.214-228, 1975.

BARNES, S.; KIRK, M.; COWARD, L. Isoflavones and their conjugates in soy foods: extraction conditions and analysis by HPLC-mass spectrometry. J. Agric. Food Chem., Columbus, v.42, p.2466-2474, 1994.

BRASIL. Ministério da Saúde. Agência Nacional de Vigilância Sanitária. Legislação. Resolução n.16, de 30 de abril de 1999. Aprova o regulamento técnico de procedimentos para registro de alimentos funcionais e ou novos ingredientes. Diário Oficial União, Brasília, 3 maio 1999. Seção 1-E, p.11.

BRASIL. Resolução n.18, de 30 de abril de 1999. Aprova o regulamento técnico que estabelece as diretrizes básicas para análise e comprovação de propriedades funcionais e ou de saúde alegadas em rotulagem de alimentos. Diário Oficial da União, Brasília, 3 maio 1999. Seção 1-E, p.11.

BINGHAM, S.A.; ATKINSON, C.; LIGGINS, J.; BLUCK, L.; COWARD, A. Plyto-oestrogens: where are we now? Br. J. Nutr., Wallingford, v.79, p.393-406, 1998. [Review]. 
BRESSANI, R. The role of soybeans in food systems. J. Am. Oil. Chem. Soc., Champaign, v.58, p.392-400, 1981.

CARROLL, K.K.; KUROWSKA, E.M. Soy consumption and cholesterol reduction: review of animal and human studies. J. Nutr., Bethesda, v.125, p.594S-597S, 1995.

CASSIDY, A.; HANLEY, B.; LAMUELA-RAVENTOS, R.M. Isoflavones, lignans and stilbenes: origins, metabolism and potential importance to human health. J. Sci. Food Agric., Bognor Regis, v.80, p.1044-1062, 2000.

COTTER, A. Genistein, appears to prevent early postmenopausal bone loss as effectively as hormone replacement therapy. Nutr. Rev., Secaucus, v.61, p.346-351, 2003.

COWARD, L.; BARNES, N.C.; SETCHELL, K.D.R.; BARNES, S. Genistein, daidzein and their $\beta$-glycoside conjugates: antitumor isoflavones in soybean foods from American and Asian diets. J. Agric. Food Chem., Columbus, v.41, p.1961-1967, 1993.

COWARD, L.; SMITH, M.; KIRK, M.; BARNES, S. Chemical modification of isoflavones in soyfoods during cooking and processing. Am. J. Clin. Nutr., Bethesda, v.68, suppl.2, p.1486S-1491S, 1998. 
CROUSE, J.R. ${ }^{\text {rd }}$; MORGAN, T.; TERRY, J.G.; ELLIS, J.; VITOLINS, M.; BURKE, G.L. A randomized trial comparing the effect of casein with that of soy protein containing varying amounts of isoflavones on plasma concentration of lipids and lipoproteins. Arch. Intern. Med., Chicago, v.159, n.17, p.2070-2076, 1999.

DIXON, R.A.; FERREIRA, D. Molecules of interest: genistein. Phytochemistry, Amsterdam, v.60, p.205-211, 2002.

ELDRIDGE, A.C.; KWOLEK, W.F. Soybean isoflavones: effect of environment and variety on composition. J. Agric. Food Chem., Columbus, v.31, p.394-396, 1983.

ERICKSON, D.R. Practical handbook of soybean processing and utilization. Saint Louis: AOCS Press, United Soybean Board, 1995. 584p.

FAO/WHO. Food and agriculture organization of the United Nations. FAO, Rome, 140p.

FDA. U.S. Food and Drug Administration. Food labeling: Health claims; soy protein and coronary heart disease. October 26, 1999. Disponível em: http://www.fda.gov/ Acesso em: 27 setembro2001.

FENNEMA, O.R. Food chemistry. 3.ed. New York: Marcel Dekker, 1996. 1069p. (Food Science and Technology Serie). 
FRIEDMAN, M.; BRANDON, D.L. Review: nutritional and health benefits of soy proteins. J. Agric. Food Chem., Columbus, v.49, n.3, p.1069-1086, 2001.

GARDNER, C.D.; NEWELL, K.A.; CHERIN, R.; HASKELL, W.L. The effect of soy protein with or without isoflavones relative to milk protein on plasma lipids in hypercholesterolemic postmenopausal women. Am. J. Clin. Nutr., Bethesda, v.73, p.728-735, 2001.

GENOVESE, M.I.; LAJOLO, F.M. Determinação de isoflavonas em derivados de soja. Cienc. Tecnol. Aliment., Campinas, v.21, n.1, p.86-93, 2001a.

GENOVESE, M.I.; LAJOLO, F.M. Isoflavonas da soja: fatores que influem nos tipos e teores em alimentos. Food Ingredients, São Paulo, v.11, p.62-64, 2001b.

GRÜN, I.U.; ADHIKARI, K.; LI, C.; LI, Y.; LIN, B.; ZHANG, J.; FERNANDO, L.N. Changes in the profile of genistein, daidzein, and their conjugates during thermal processing of tofu. J. Agric. Food Chem., Columbus, v.49, n.6, p.2839-2843, 2001.

HARRIS, E.L.V. ANGAL, S., eds. Protein purification methods: a practical approach. New York: Oxford University Press, 1989. 317p. (Pratical Approach Series). 
HERMANSSON, A.M. Physico-chemical aspects of soy protein structure formation. J. Texture Stud., Trumbull, v.9, p.33-58, 1978.

HJELMELAND, L.M.; CHRAMBACH, A. Electrophoresis and electrofocusing in detergent containing media: a discussion of basic concepts. Electrophoresis, Weinheim, v.2, n.1, p.1-11, 1981.

HODGSON, J.M.; CROFT, K.D.; PUDDEY, I.B.; MORI, T.A.; BEILIN, L.J. Soybean isoflavonoids and their metabolic products inhibit in vitro lipoprotein metabolism. J. Nutr. Biochem., New York, v.7, p.664-669, 1996.

HOLLINGSWORTH, P. Functional foods: fad or fact? Food Technol., Chicago, v.49, n.4, p.32-34, 1995.

HUTCHINS, A.M.; SLAVIN, J.; LAMPE, J.W. Urinary isoflavonoid phytoestrogen and lignan excretion after consumption of fermented and unfermented soy products. J. Am. Diet. Assoc., Chicago, v.95, n.5, p.545-551, 1995.

ISHIMI, Y.; YOSHIDA, M.; WAKIMOTO, S.; WU, J.; CHIBA, H.; WANG, X.; TAKEDA, K.; MIYAURA, C. Genistein, a soybean isoflavone, affects bone marrow lymphopoiesis and prevents bone loss in castrated male mice. Bone, New York, v.31, n.1, p.180-185, 2002. 
IZUMI, T.; PISKULA, M.K.; OSAWA, S.; OBATA, A.; TOBE, K.; SAITO, M.; KATAOKA, S.; KUBOTA, Y.; KIKUCHI, M. Soy isoflavone aglycones are absorbed faster and in higher amounts than their glucosides in humans. J. Nutr., Bethesda, v.130, n.7, p.1695-1699, 2000.

IWABUCHI, S.; YAMAUCHI, F. Effects of heat and ionic strength upon dissociation-association of soybean protein fractions. J. Food Sci., Chicago, v.49, p.1289-1294, 1984.

IYENGAR, R.B.; RAVESTEIN, P. New aspects of subunit structure of soybean glycinin. Cereal Chem., Saint Paul, v.58, p.325-330, 1981.

KINSELLA, J.E. Functional properties of soy proteins. J. Am. Oil Chem. Soc., Champaign, v.56, p.242-258, 1979.

KUDOU, D.; FLEURY, Y.; WELTI, D.; MAGNOLATO, D.; UCHIDA, T.; KITAMURA, K.; OKUBO, K. Malonyl isoflavone glycosides in soybean seeds (Glycine max Merrill). Agric. Biol. Chem., Tokyo, v.55, n.9, p.2227-2233, 1991.

KULLING, S.E.; HONIG, D.M.; METZLER, M. Oxidative metabolism of the soy isoflavones daidzein and genistein in humans in vitro and in vivo. J. Agric. Food Chem., Columbus, v.49, n.6, p.3024-3033, 2001.

KURZER, M.S.; XU, X. Dietary phytoestrogens. Annu. Rev. Nutr., Palo Alto, v.17, p.353-381, 1997. 
LAEMMLI, U.K. Cleavage of structural proteins during the assembly of the head of bacteriophage T4. Nature, London, v.227, p.680-685, 1970.

LEE, S.J.; YAN, W.; AHN, J.K.; CHUNG, M. Effects of year, site, genotype and their interactions on various soybean isoflavones. Field Crops Res., Amsterdam, v.81, p.181-192, 2003.

LINASSIER, C.; PIERRE, M.; LE PECO, J.B.; PIERRE, J. Mechanism of action in NIH-3T3 cells of genistein, an inhibitor of EGF receptor tyrosine kinase activity. Biochem. Pharmacol., New York, v.39, p.187-193, 1990.

LIU, K. Soybean: chemistry, technology and utilization. New York: Chapman \& Hall, 1997. 532p.

LOWRY, O.H.; ROSEBROUGH, N.J.; FARR, A.L.; RANDALL, R.J. Protein measurement with the Folin phenol reagent. J. Biol. Chem., Birmingham, v.193, p.265-275, 1951.

MAHUNGU, S.M.; DIAZ-MERCADO, S.; LI, J.; SCHWENK, M.; SINGLETARY, K.; FALLER, J. Stability of isoflavones during extrusion processing of corn/soy mixture. J. Agric. Food Chem., Columbus, v.47, p.279-284, 1999.

MATSUURA, M.; OBATA, A. $\beta$-glucosidases from soybeans hydrolyze daidzin and genistin. J. Food Sci., Chicago, v.58, n.1, p.144-147, 1993. 
MATSUURA, M.; OBATA, A.; FUKUSHIMA, D. Objectionable flavor of soy milk developed during the soaking of soybeans and its control. J. Food Sci., Chicago, v.54, n.3, p.602-605, 1989.

MATSUURA, M.; SASAKI, J.; MURAO, S. Studies on $\beta$-glucosidases from soybeans that hydrolyze daidzin and genistin: isolation and characterization of an isozyme. Biosci., Biotechnol., Biochem., Tokyo, v.59, n.9, p.1623-1627, 1995.

MORRISON, R.T.; BOYD, R.N. Química orgânica. 7.ed. Lisboa: Fundação Calouste Gulbenkian, 1981. 1498p.

NAKAMURA, Y.; TSUJI, S.; TONOGAI, Y. Determination of the levels of isoflavonoids in soybean and soy-derived foods and estimation of isoflavonoids in the Japanese daily intake. $\mathbf{J}$. AOAC Int., Gaithersburg, v.83, n.3, p.635-650, 2000.

PANDJAITAN, N.; HETTIARACHCHY, N.; JU, Z.Y. Enrichment of genistein in soy protein concentrate with $\beta$-glucosidase. Food Chem. Toxicol., Amsterdam, v.65, n.3, p.403-407, 2000.

PETRUCCELLI, S.; AÑóN, M.C. Soy protein isolates components and their interactions. J. Agric. Food Chem., Columbus, v.43, p.1762-1767, 1995b.

PETRUCCELLI, S.; AÑóN, M.C. Thermal aggregation of soy protein isolates. J. Agric. Food Chem., Columbus, v.43, p.3035-3041, 1995a. 
POTTER, S.M.; BAUM, J.A.; TENG, H.; STILLMAN, R.; SHAY, N.F.; ERDMAN Jr., J.W. Soy protein, and isoflavones: their effects on lipids and bone density in postmenopausal women. Am. J. Clin. Nutr., Bethesda, v.68, p.1375S-1379S, 1998.

PRATT, D.E.; BIRAC, P.M. Source of antioxidant activity of soybeans and soy products. J. Food Sci., Chigago, v.44, p.1720-1722, 1979.

ROCHA, J.M.S. Aplicações de agentes tensioactivos em biotecnologia. Bol. Biotecnol., São Paulo, v.64, p.5-11, 1999.

SETCHELL, K.D.R. Phytoestrogens: the biochemistry, physiology, and implications for human health of soy isoflavones. Am. J. Clin. Nutr., Bethesda, v.68, suppl.3, p.1333S-1346S, 1998.

SETCHELL, K.D.R.; BORRIELLO, S.P.; HULME, P.; KIRK, D.N.; AXELSON, M. Nonsteroidal estrogens of dietary origin: possible roles in hormone-dependent disease. Am. J. Clin. Nutr., Bethesda, v.40, p.569-578, 1984.

SETCHELL, K.D.R.; BROWN, N.M.; NECHEMIAS, L.Z.; BRASHEAR, W.T.; WOLFE, B.E.; KIRSCHNER, A.S.; HEUBI, J.E. Evidence for lack of absorption of soy isoflavone glycosides in humans, supporting the crucial role of intestinal metabolism for bioavailability. Am. J. Clin. Nutr., Bethesda, v.76, p.447-453, 2002. 
SETCHELL, K.D.R.; CASSIDY, A. Dietary isoflavones: biological effects and relevance to human health. J. Nutr., Bethesda, v.129, n.3, p.758S-767S, 1999.

SIMONNE, A.H.; SMITH, M.; WEAVER, D.B.; VAIL, T.; BARNES, S.; WEI, C.I. Retention and changes of soy isoflavones and carotenoids in immature soybean seeds (Edamame) during processing. J. Agric. Food Chem., Columbus, v.48, p.60616069, 2000.

SOMEKAWA, Y.; CHIGUCHI, M.; ISHIBASHI, T.; ASO, T. Soy intake related to menopausal symptoms, serum lipids, and bone mineral density in postmenopausal Japanese women. Obstet. Gynecol., New York, v.97, n.1, p.109-115, 2001.

SONG, T.; BARVA, K.; BUSEMAN, G.; MURPHY, P.A. Soy isoflavone analysis: quality control and a new internal standard. Am. J. Clin. Nutr., Bethesda, v.68, supp.4, p.1475S-1479S, 1998.

SONG, T.; HENDRICH, S.; MURPHY, P.A. Estrogenic activity of glycitein, a soy isoflavone. J. Agric. Food Chem., Columbus, v.47, p.1607-1610, 1999.

THANH, V.H.; SHIBASAKI, K. Major proteins of soybean seeds: a straightforward fractionation and their characterization. J. Agric. Food Chem., Columbus, v.24, n.6, p.1117-1121, 1976. 
THANH, V.H.; SHIBASAKI, K. Major proteins of soybean seeds: reversible and irreversible dissociation of $\beta$-conglycinin. J. Agric. Food Chem., Columbus, v.27, p.805-809, 1979.

THANH, V.H.; SHIBASAKI, K. Major proteins of soybean seeds: subunit structure of $\beta$-conglycinin. J. Agric. Food Chem., Columbus, v.26, p.692-695, 1978.

THANH, V.H.; SHIBASAKI, K. $\beta$-conglycinin from soybean proteins: isolation and immunological and physicochemical properties of the monomeric forms. Biochim. Biophys. Acta, Amsterdam, v.490, p.370-384, 1977.

THORBURN, J.; THORBURN, N. The tyrosine kinase inhibitor, genistein, prevents $\alpha$-adrenergic-induced cardiac muscle cell hypertrophy by inhibiting activation of the Ras-MAP kinase signaling pathway. Biochem. Biophys. Res. Commun., Orlando, v.22, p.1586-1591, 1994.

UTSUMI, S.; DAMODARAN, S.; KINSELLA, J.E. Heat-induced interactions between soybean proteins: preferential association of $11 \mathrm{~S}$ basic subunits and $\beta$ subunits of 75 . J. Agric. Food Chem., Columbus, v.32, p.1406-1412, 1984.

VISSER, A.; THOMAS, A. Review: soya protein products - their processing, functionality, and application aspects. Food Rev. Int., Monticello, v.3, n.1/2, p.1-32, 1987. 
WAGNER, J.R.; SORGENTINI, D.A.; AÑóN, M.C. Relation between solubility and surface hydrophobicity as an indicator of modifications during preparation processes of commercial and laboratory-prepared soy protein isolates. J. Agric. Food Chem., Columbus, v.48, p.3159-3165, 2000.

WANG, C.; MA, Q.; PAGADALA, S.; SHERRARD, M.S.; KRISHNAN, P.G. Changes of isoflavones during processing of soy protein isolates. J. Am. Oil Chem. Soc., Champaign, v.75, p.337-341, 1998.

WANG, H.; MURPHY, P.A. Isoflavone content in commercial soybean foods. J. Agric. Food Chem., Columbus, v.42, p.1666-1673, 1994a.

WANG, H.; MURPHY, P.A. Isoflavone composition of American and Japanese soybean in Iowa: effects of variety, crop year, and location. J. Agric. Food Chem., Columbus, v.42, p.1674-1677, 1994b.

WANG, H.J.; MURPHY, P.A. Mass balance study of isoflavones during soybean processing. J. Agric. Food Chem., Columbus, v.44, p.2377-2383, 1996.

WOLF, W.J.; COWAN, J.C. Soybeans as a food source. London: Butterworths, 1971. 86p. (CRC monotopics series). 
WOLF, W.J. Scanning electron microscopy of soybean protein bodies. J. Am. Oil Chem. Soc., Champaign, v.47, p.107-108, 1970.

XU, X.; HARRIS, K.S.; WANG, H.; MURPHY, P.; HENDRICH, S. Bioavailability of soybean isoflavones depends on gut microflora in women. J. Nutr., Bethesda, v.125, p.2307-2315, 1995.

YEOH, H.; WEE, Y. Some properties of $\beta$-glucosidases from tropical plant species. Phytochemistry, Amsterdam, v.35, n.6, p.1391-1393, 1994. 